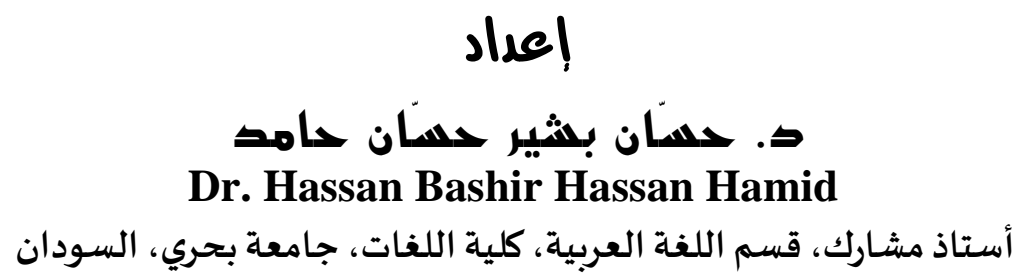

Doi: 10.21608/mdad.2021.184425

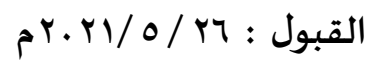

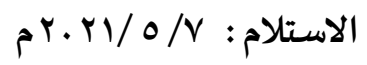

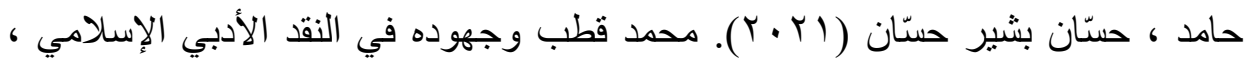

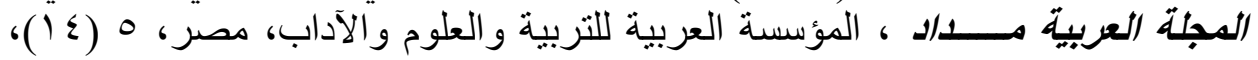

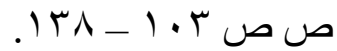




\section{محمد قطب وجهوده في النقد الأدبي الإسلامي}

\section{المستخلص :}

تناولت هذه الدراسة محمد قطب وجهوده النظرية والتطبيقية في النقد الأدبي

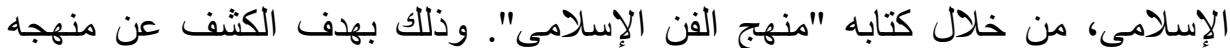

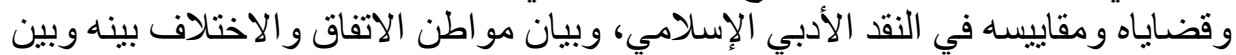

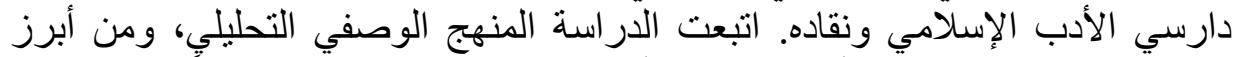

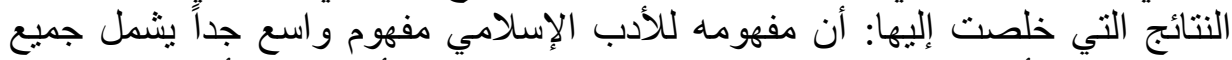

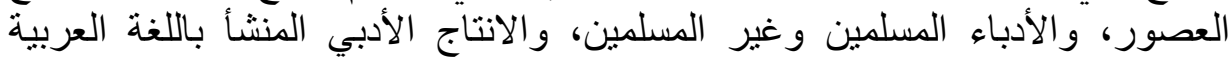

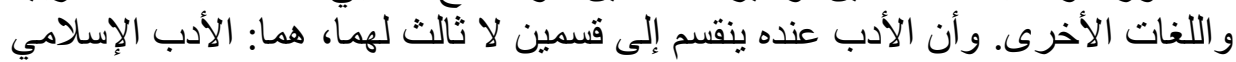

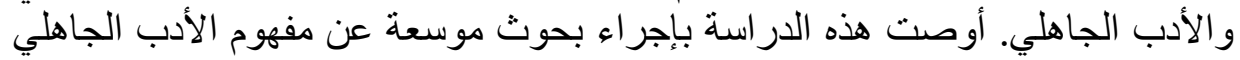
عند محمد قطب، وكذللك مقومات القات القصة الإسلامية عنده. الكلمات مفتاحية: الأدب الجاهلي، الأدب الإسلامي، القصة الإسلامية.

\section{Abstract:}

This study dealt with Mohammed Qutb and his theoretical and applied efforts in Islamic literary criticism, through his book "The Methodology of Islamic Art". The aim was reveal the approach, issues, and Islamic literary criticism standards that Qutb had adopted in which the aspects of agreement and difference with other scholars and critics of Islamic literature are explained. The study followed the descriptive and analytical approach. Its most prominent findings are: his concept of Islamic literature is a very wide in its scope, one that includes all eras, Muslim and nonMuslim writers, and literary production originating from Arabic and other language; and that literature for him is divided into two parts only, namely: Islamic literature and pre-Islamic literature. Therefore, the study recommended the conduction of further research on Mohammed Qutb's concept of pre-Islamic literature as well as the element and structure of Islamic fiction in his writing.

Keywords: pre-Islamic literature, Islamic literature, Islamic fiction. 


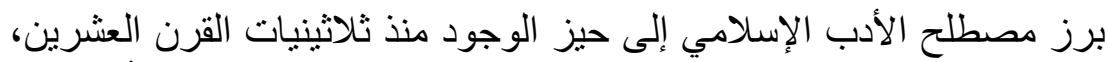

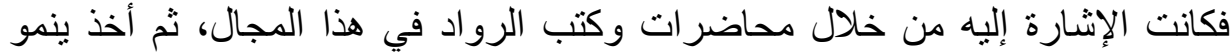

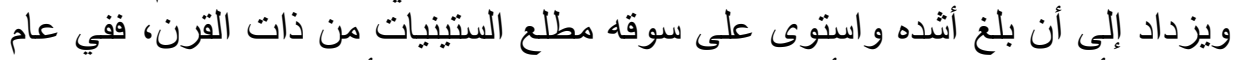

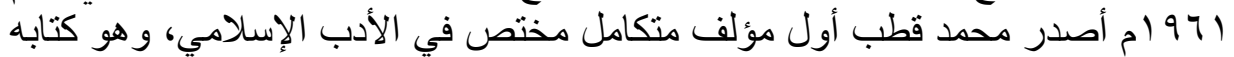

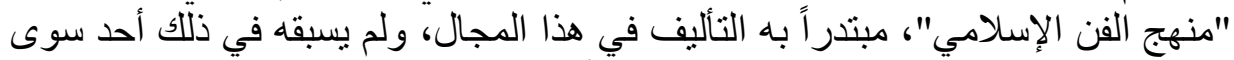

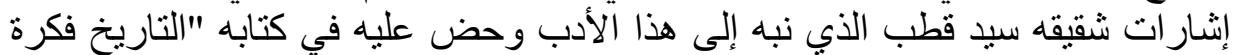

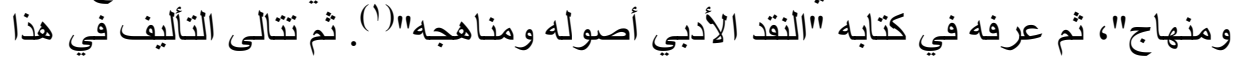

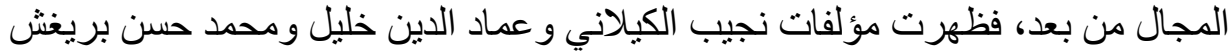
و غير هم.

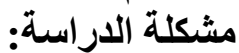

تتمثل مشكلة هذه الدراسة في نقطتين أساسيتين، الأولى: تدور في فلك شخصية

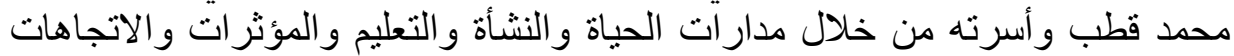

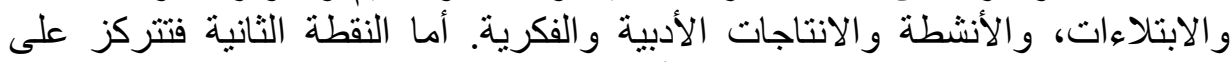

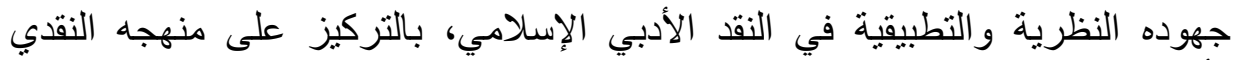
و أهدافه، و وقضاياه النقدية، ومقائيسة والنية التطبيقية.

تكمن أهمية هذه الدراسة في مقدار القيمة العلمية التي تضيفها إلى المعرفة

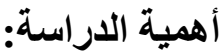
الإنسانية، كما تكمن في تناولها للأدب الإسلامي و النقا الأدبي الإسلامي نظرياً وتطبيقياً.

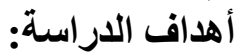
ا ا ـ إلقاء الضوء على شخصية محمد قطب ودور ها في الأدب و النقد الإسلاميين. r r إبراز جهوده ومنهجه وقضاياه ومقاييسه في النقد الأدبي الإسلامي.

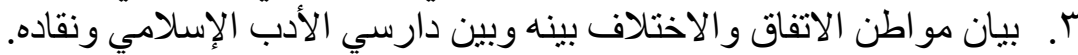

تعنمد هذه الدر اسة على المنهج الوصفي التحليلي، لأنه الأنسب لمثل هذا النوع

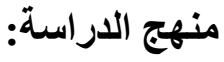

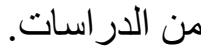
حدود الدراسة: من الاسات تتحصر الحدود الموضو عية لهذه الدراسة في إبراز جهود محمد قطب في النقد الإسل الأدبي الإسلامي من خلال كتابه "منهج الفن الإسلامي".

(') الأدب الإسلامي: مراجعات في النشأة والخصائص، ماجد محمد الماجد، جامعة الملك

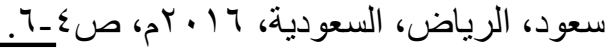
1.0 
محمد قطب إبر اهيم حسين شاذلي ()، مفكر إسلامي مصري، يرجع أصله إلى في إنى

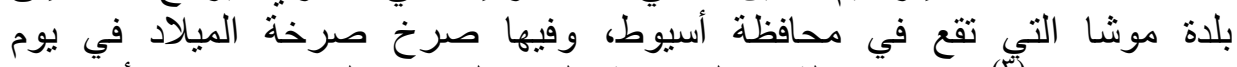

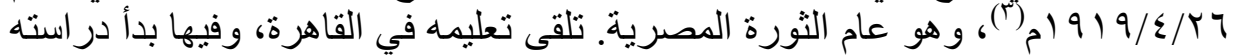

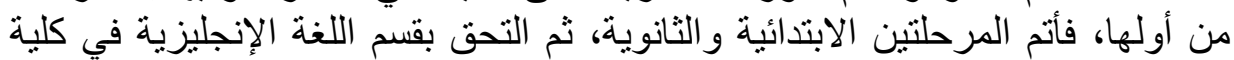

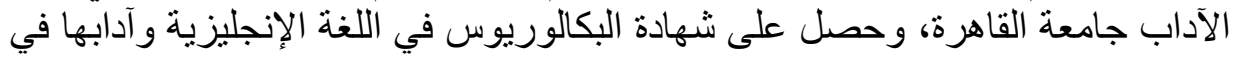

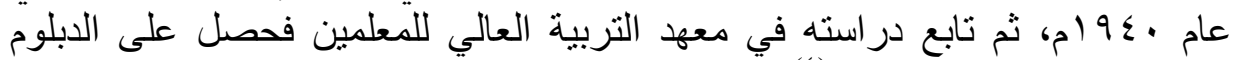

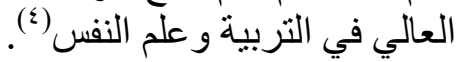
انضم إلى جماعة الإخوان المسلمين في مطلع الخمسينيات، بعد انضمان الخمام أخيه

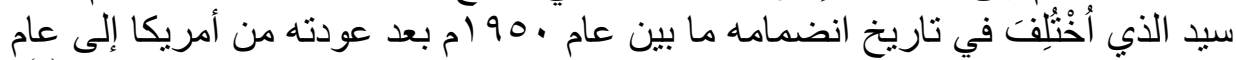

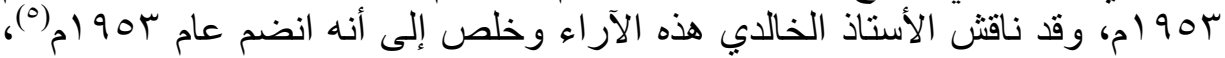

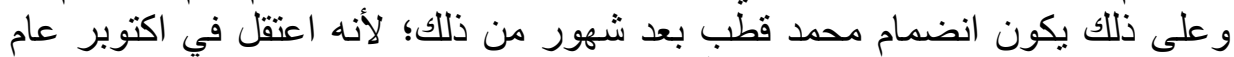

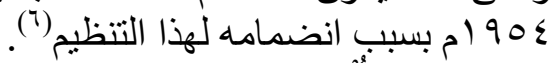

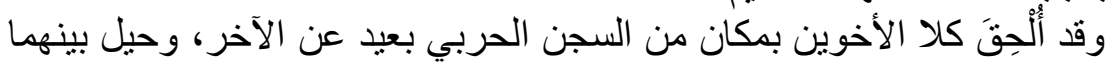

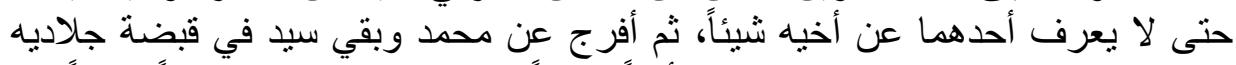

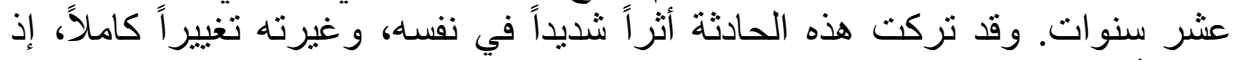

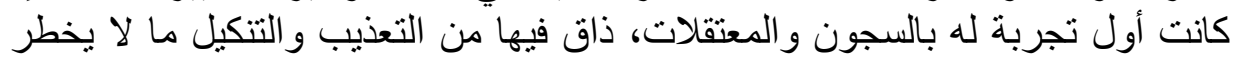

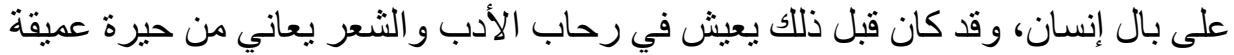

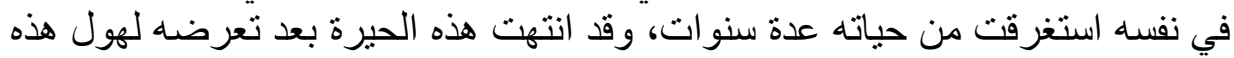

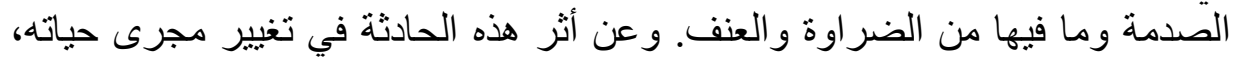

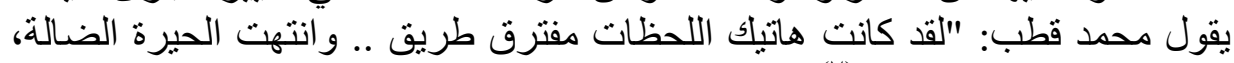

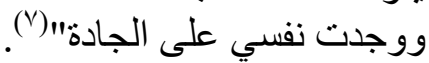

(r) سيد قطب الأديب الناقد، والداعية المجاهد والمفكر المفسر الرائد، صلاح عبد الفتاح

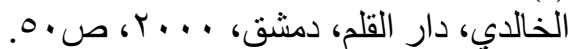

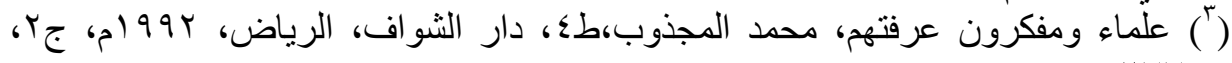
ص ص

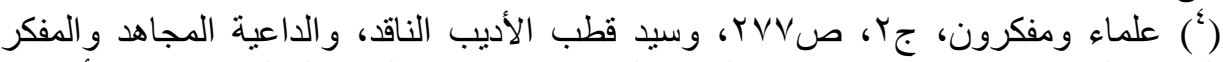

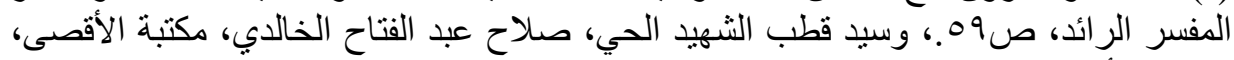

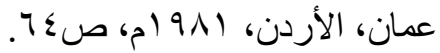

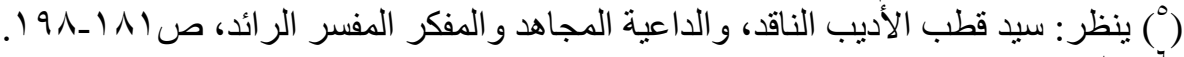

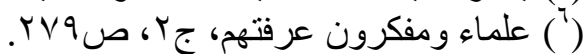
r . - - - 
أُعيد محمد قطب إلى السجن مرة أخرى عام 970 (م، و عُذِّبَ فيه عذاباً شُديداً

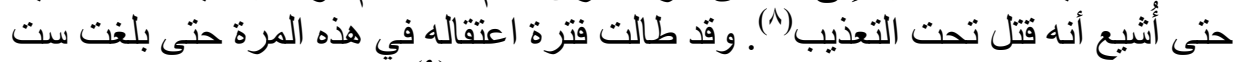

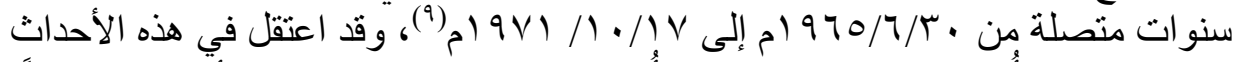

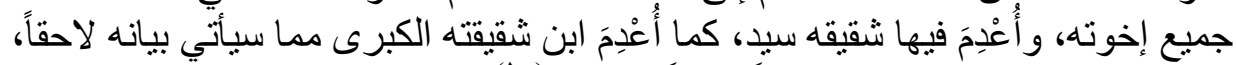

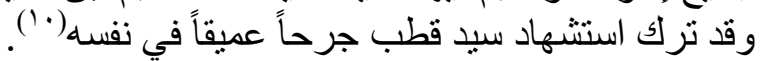

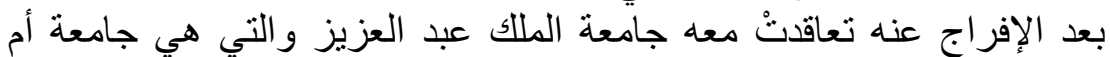

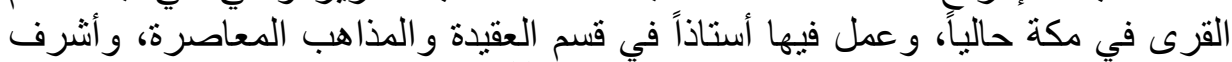

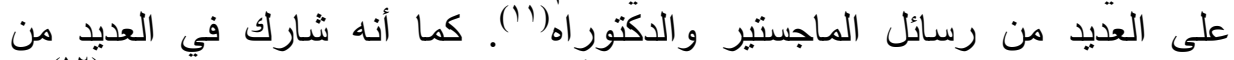

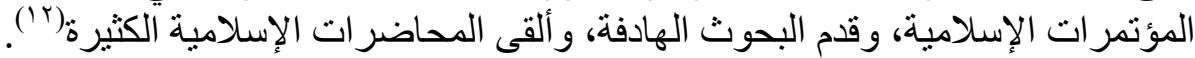

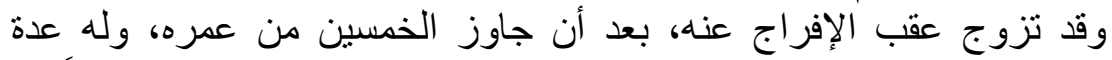

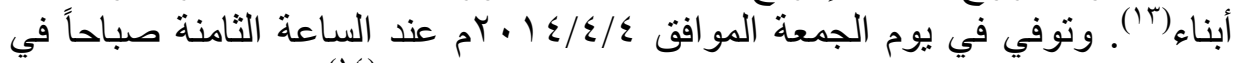

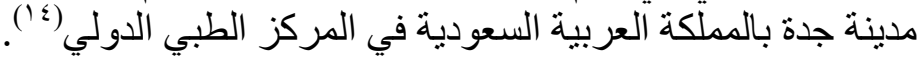

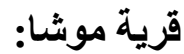

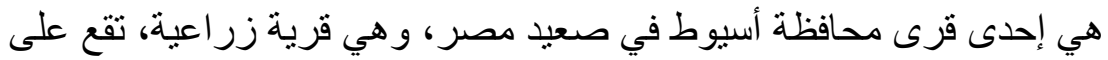

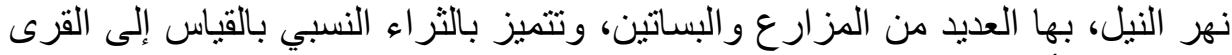

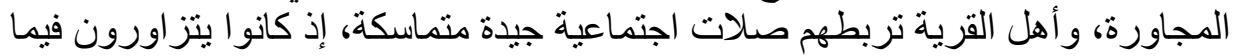

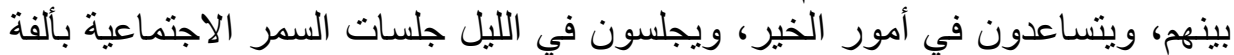

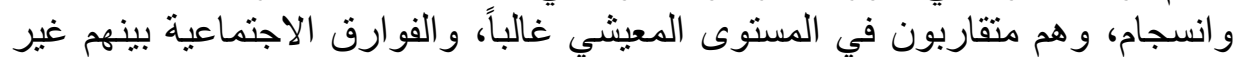

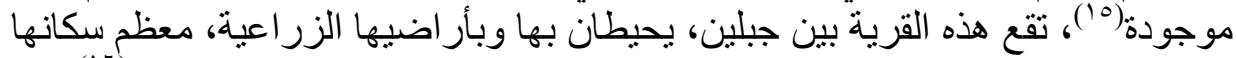

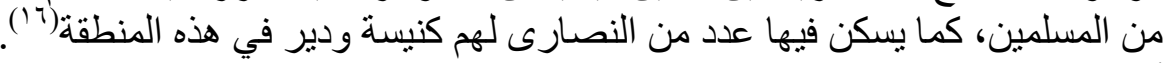
أسرته: (- nن

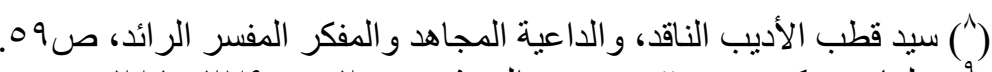

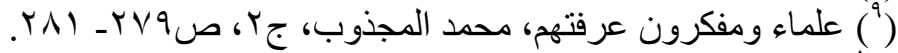

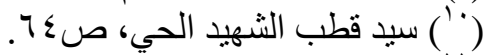

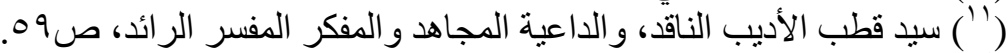

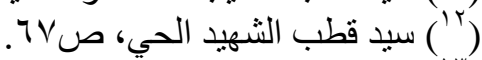

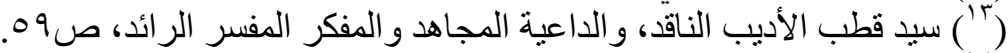

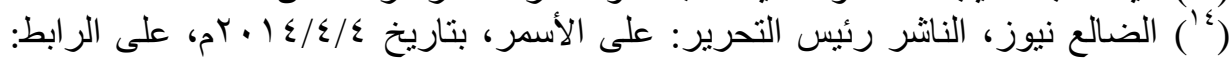

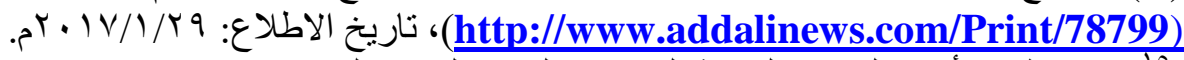

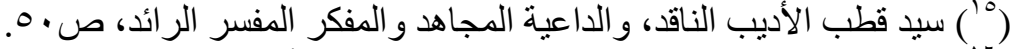

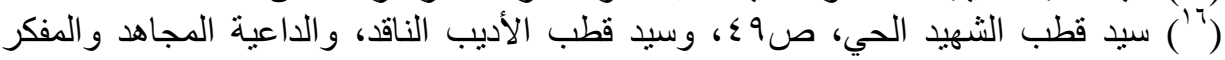
$\overline{1 \cdot V}$ 


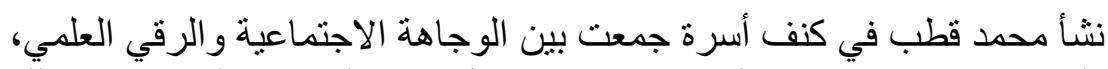

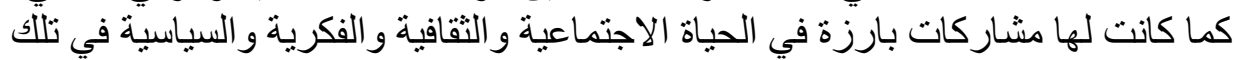
الفترة، وما زالت الت آثاره باقية إلى اليوم.

والاه:

هو الحاج قطب إبر اهيم حسين شاذلي، اختلف في أصله أمصري هو أم هندي

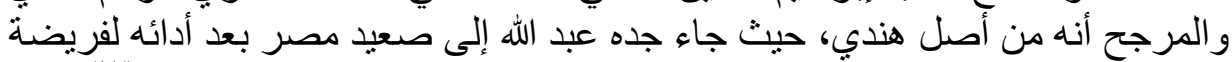

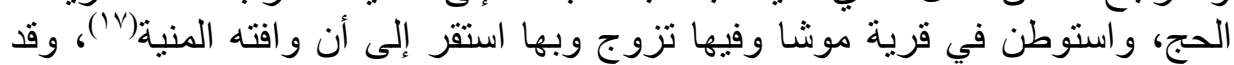

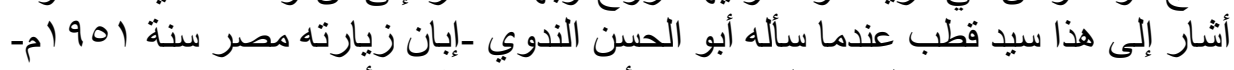

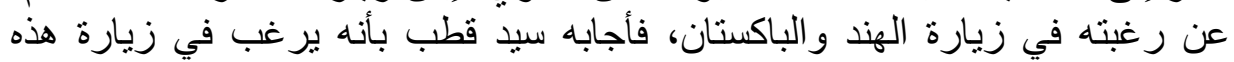

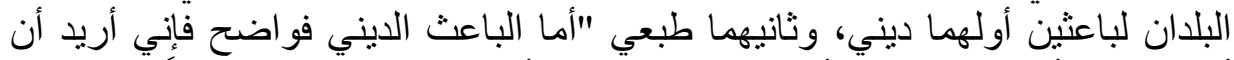

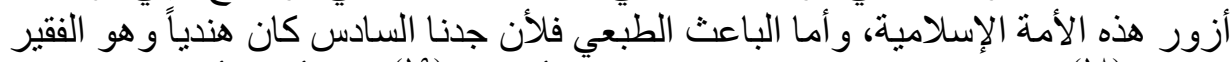

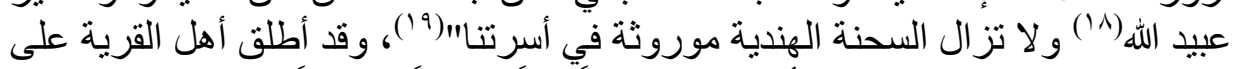

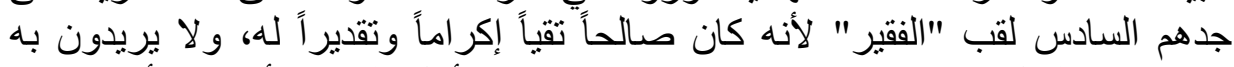

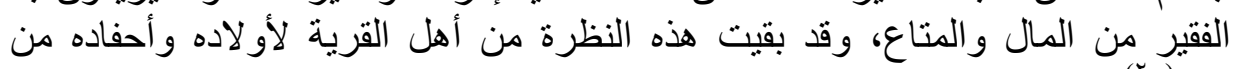

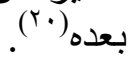
صسار الحاج قطب إبراهيم عميدَ أسرته ووجيََ قريته، ذا نشاط سياسي وثقافي

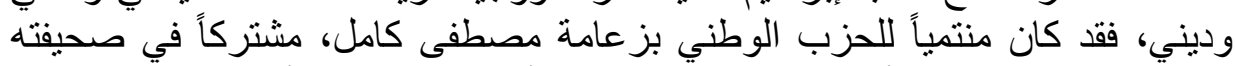

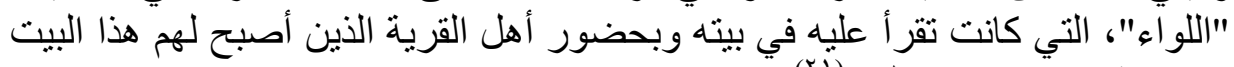

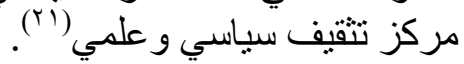

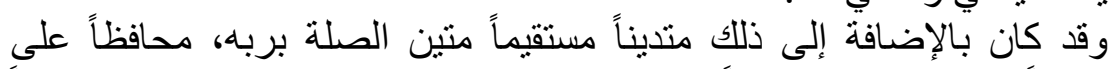

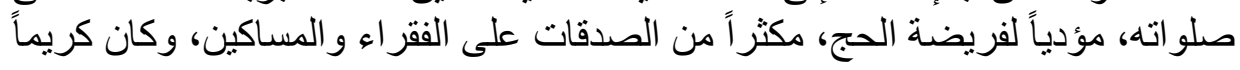

(v) سيد قطب الأديب الناقد، والداعية المجاهد و المفكر المفسر الر ائد، ص.0. ه، وسيد قطب الثهيد الحي، صلان الادي (1) ورد الاسم في كتاب الندوي هكذا، وبه تصحيف وصوابه وابه عبد الله، صححه الدكتور

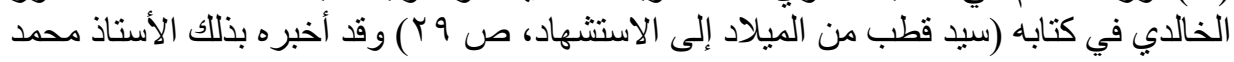

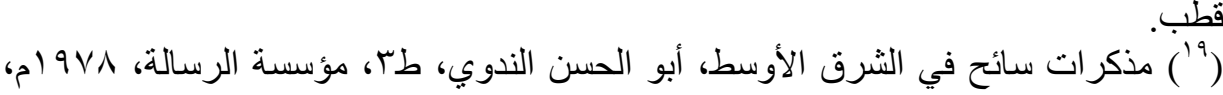
صr

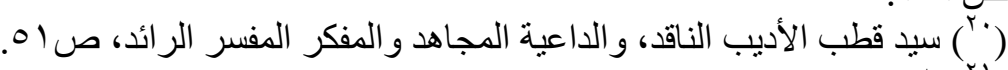

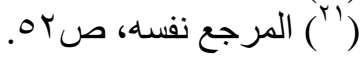




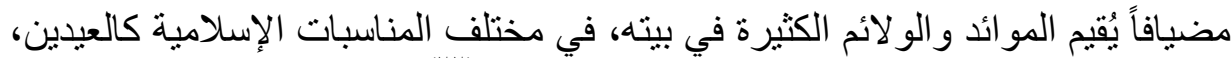

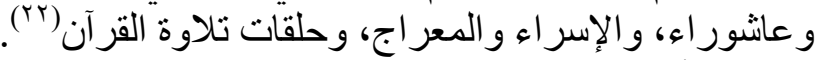

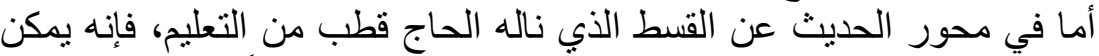

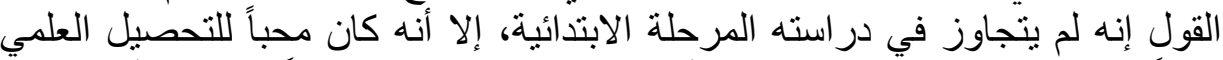

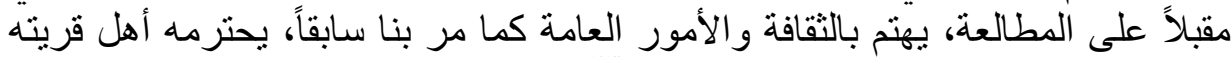

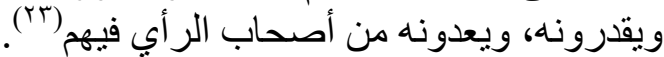

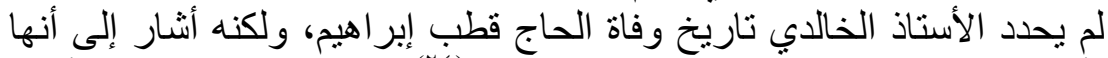

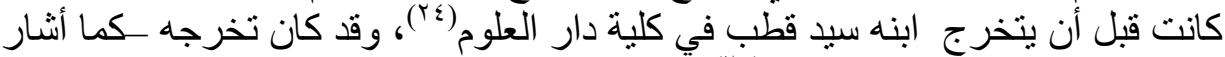

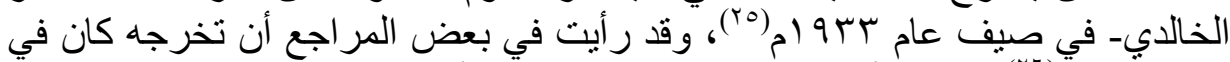

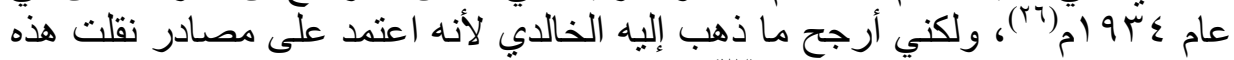

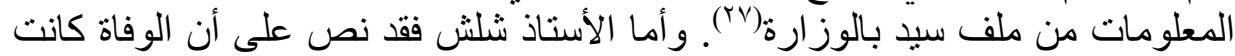

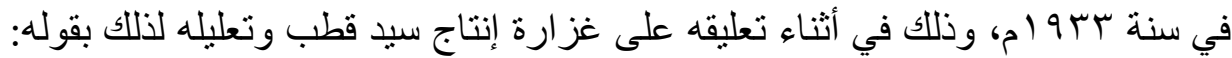

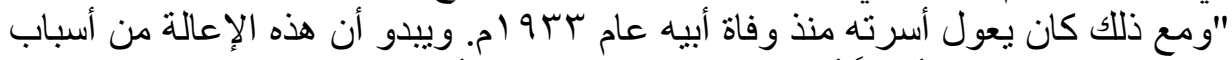

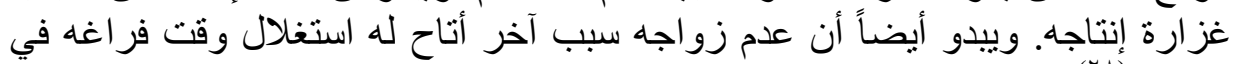

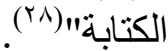
ويمكن الجمع والتقريب بين هذه الروايات بأن الحاج قطب توفي نفس عام تخرج ابنه سيد ولكن قبل بضعة وأثنهر من ذلك. والاتهة: - من

هي السيدة فاطمة حسين عثمان، من عائلة مرموقة عند أهالى القرية أيضاً( (19)،

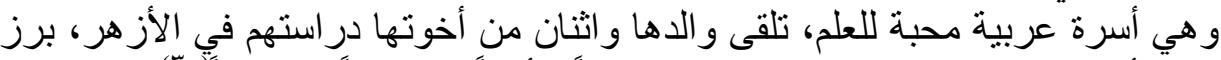

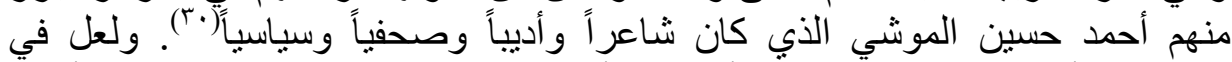

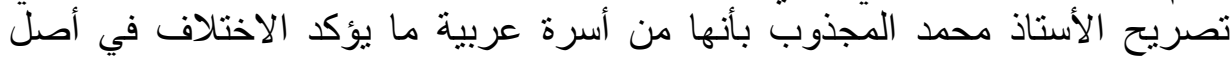

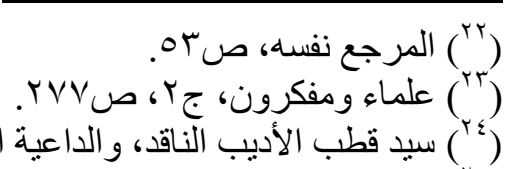

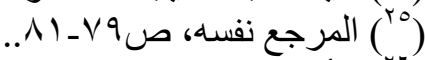

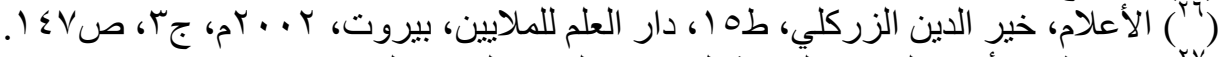

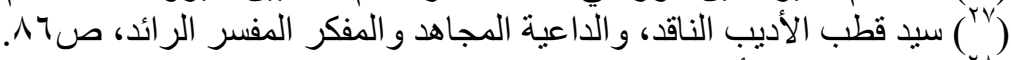

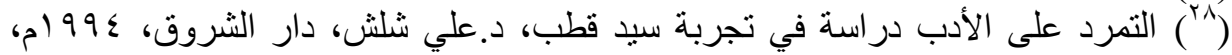
ص rاr.

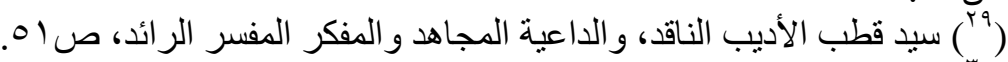
$1 \cdot 9$

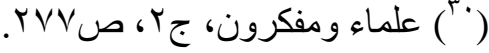




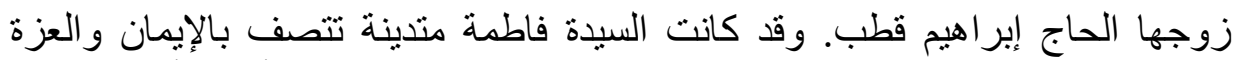

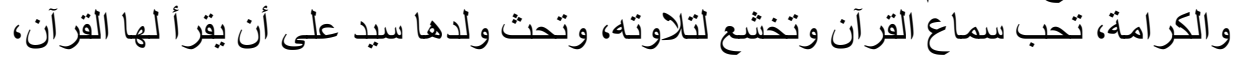

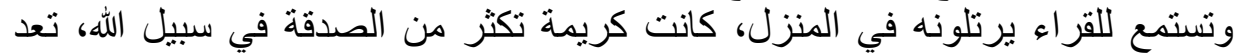

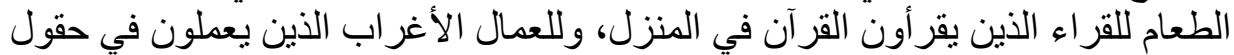

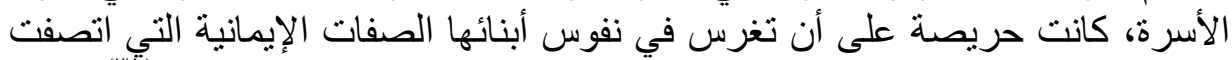

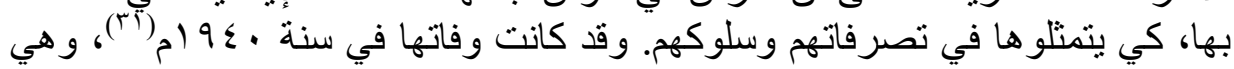
نفس السنة التي تخرج في فيها ابنها محمد من الجامعة.

هي المولودة الأولى في الأسرة، ولدت عام ب ـ 9 (م، فقد كانت تكبر أخاها سيد نفيسة قطب:

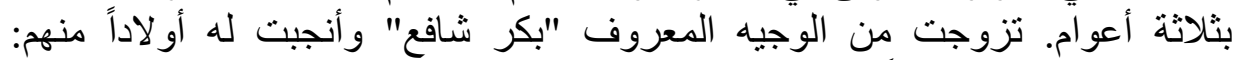

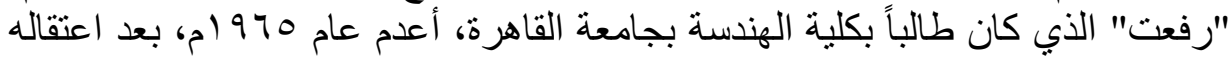

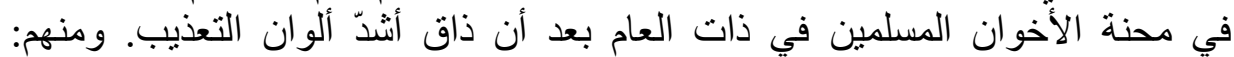

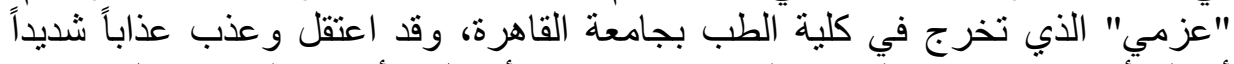

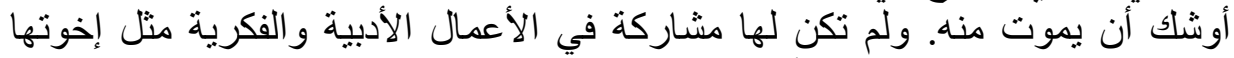

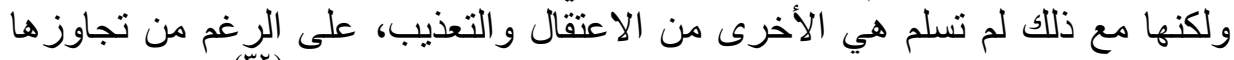

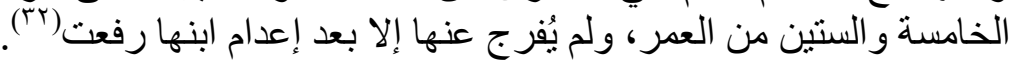

فهو سيد قطب المفكر الإسلامي المصري المعروف الذي ولد في قرية موشا سيد قطب:

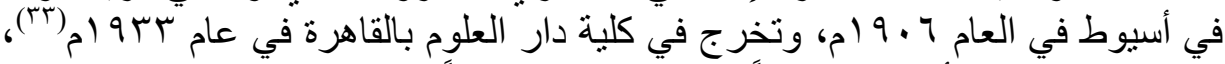

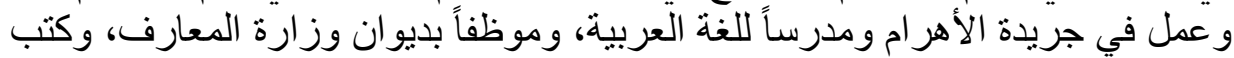

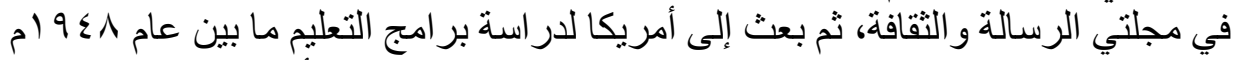

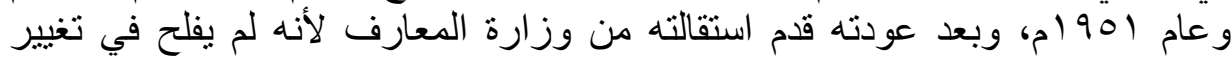

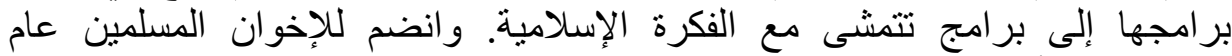

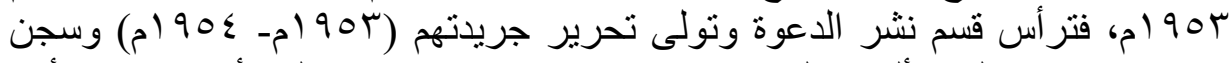
معهم، فعكف على تأليف الكتب ونشرها ونى وهو هو في سجنه، إلى أن صدر الأهر

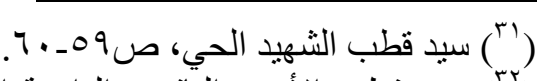

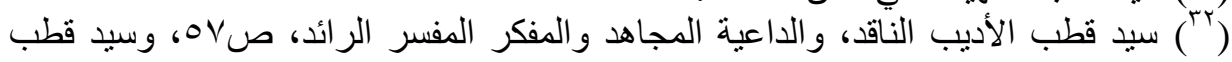

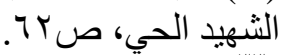

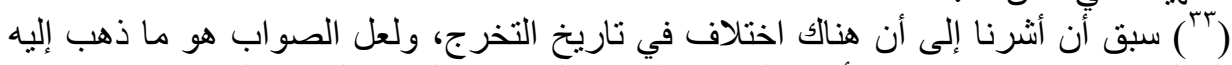

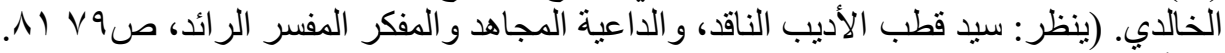

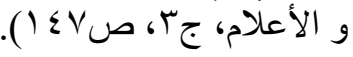




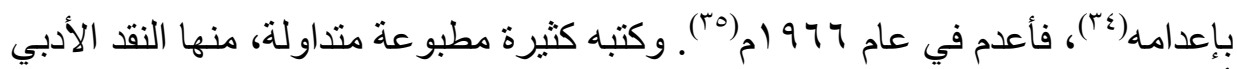

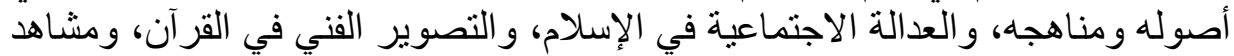

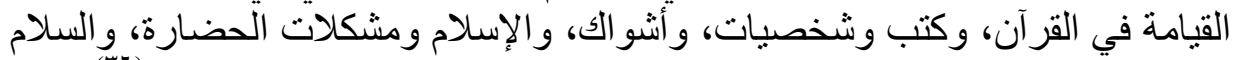

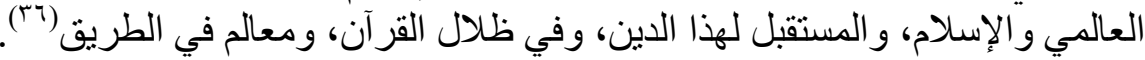

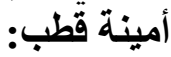

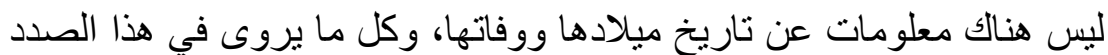

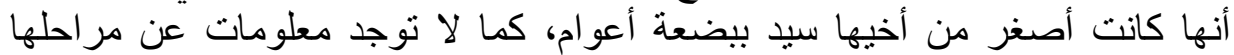

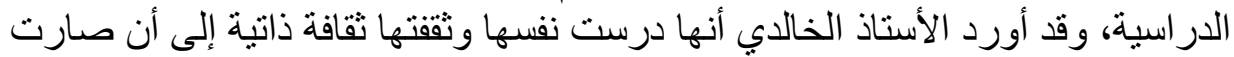

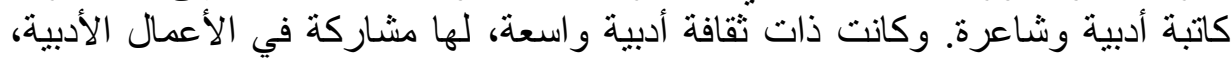

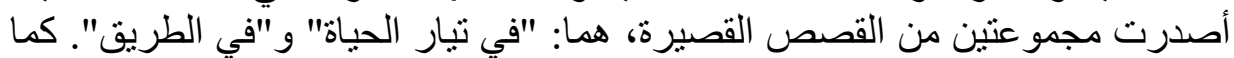

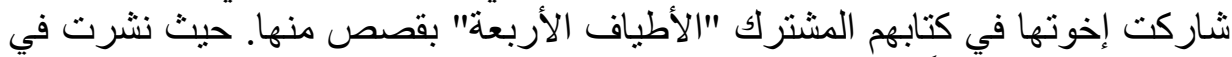

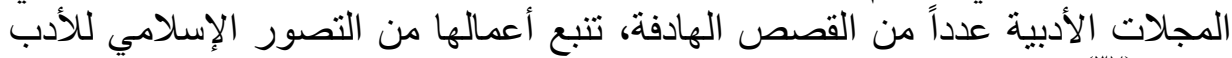

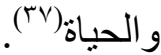

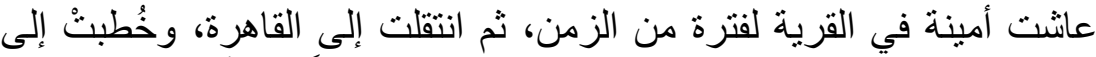

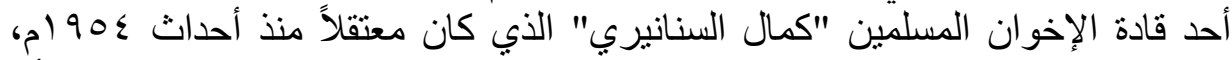

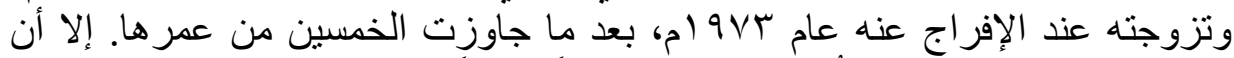

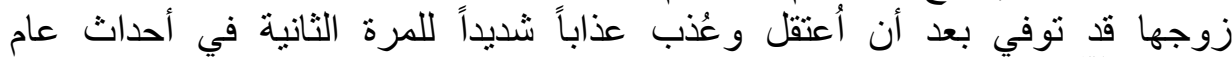

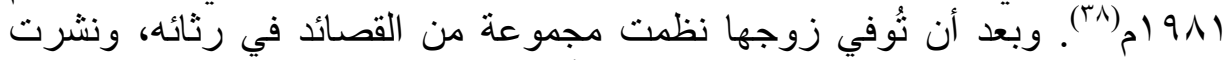

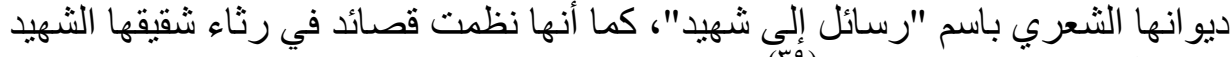

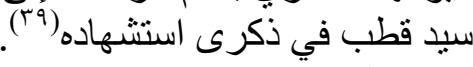

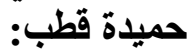

هي المولودة الصغرى في الأسرة، لم تتو افر المعلومات عن تاريخ ميلادها

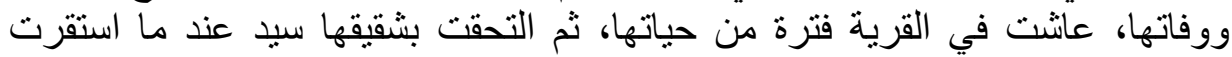

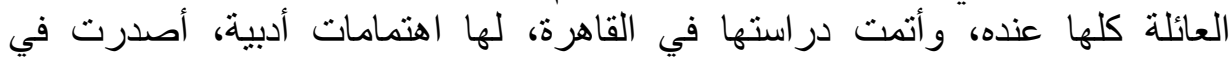

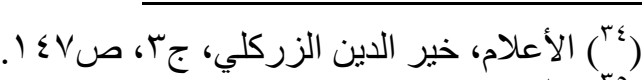

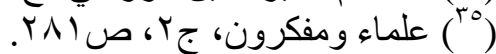

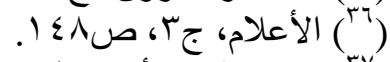

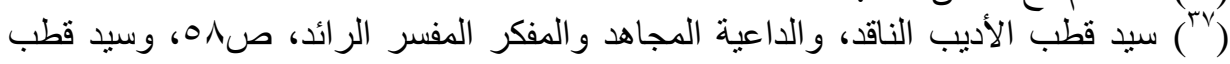

الثهيد الحي، صنب الآب.

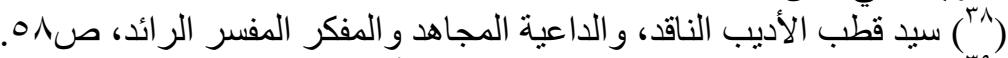

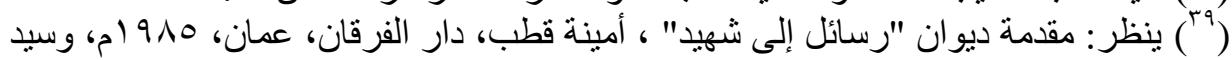

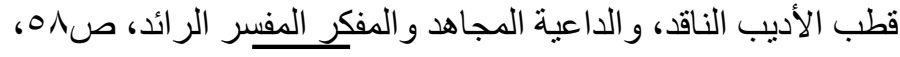


الأربعينيات مع إخوتها الأربعة كتاب "الأطياف الأربعة" وهو كتاب أدبي، كما أنها

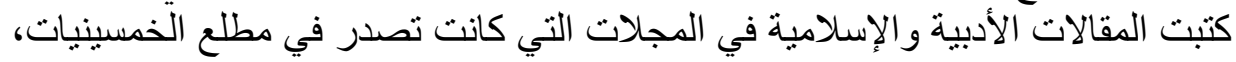

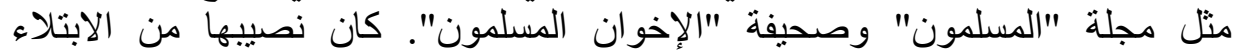

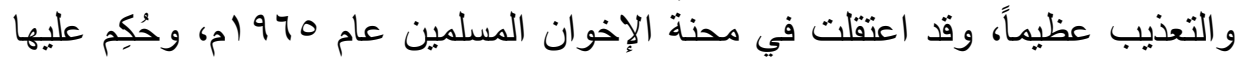

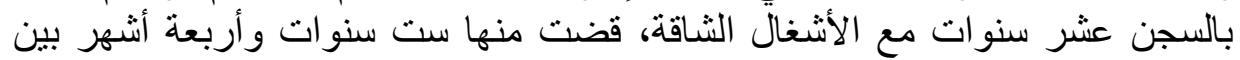

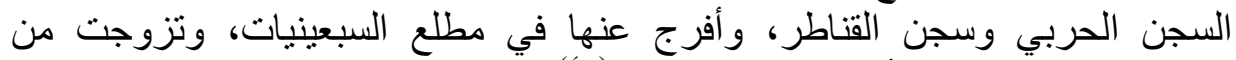

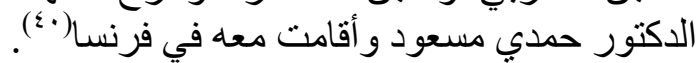
المؤثرات الفكرية و الثقافية:

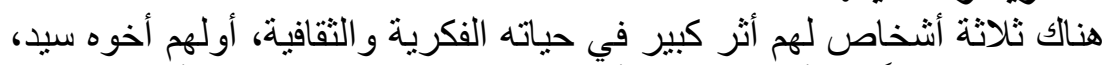

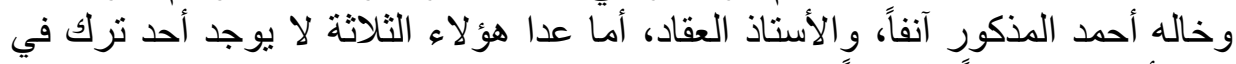

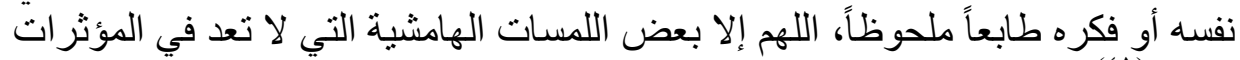

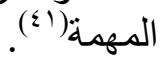
أثر سبد قطب:

من أعمق الرجال تأثثراً في توجيهه وتفكيره، بل أعظم الناس في حياته كلها،

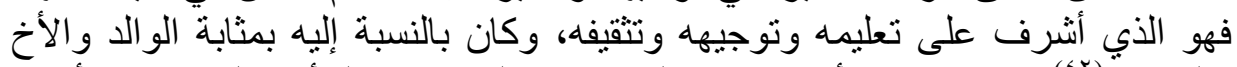

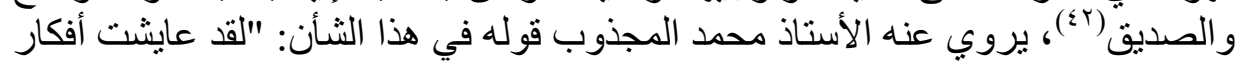

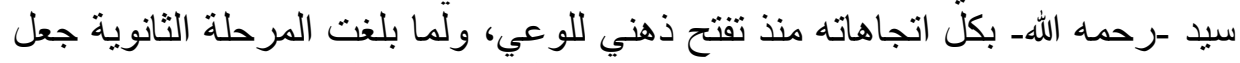

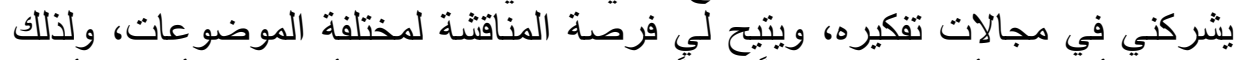

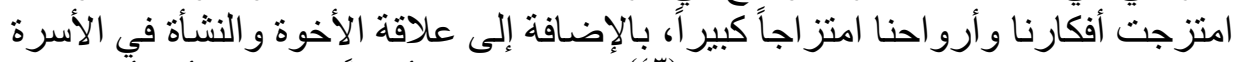

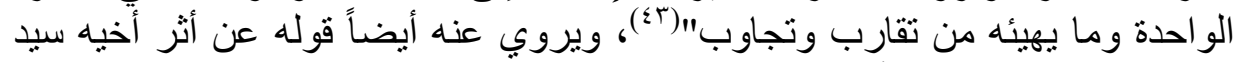

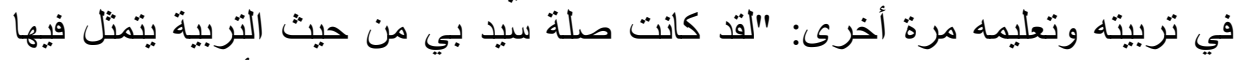

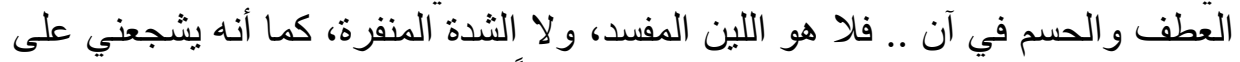

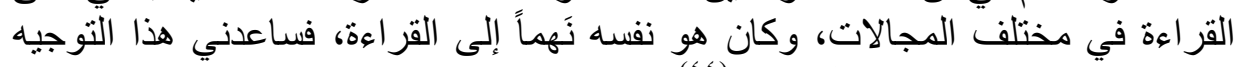
على حب الاطلاع منذ عهد الطفولة" (؛ ؛ ؛ .

(") سيد قطب الأديب الناقد، والداعية المجاهد والمفكر المفسر الرائد، صبآ، وسيد قطب

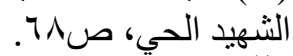
(rVA ( rVA ( $)$ 
حبب سيد قطب في نفس شقيقه الكتابة الأدبية والفنية، فكتب محمد المقالة، ونظم

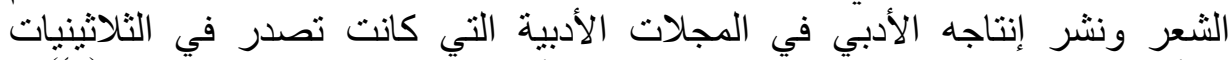

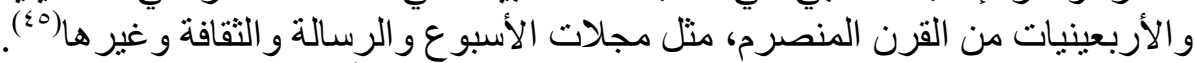

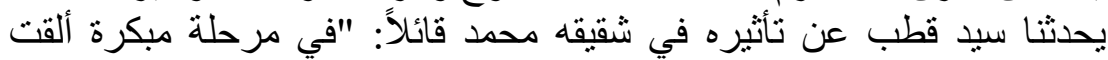

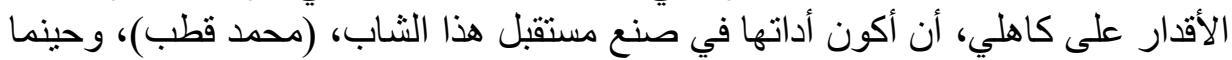

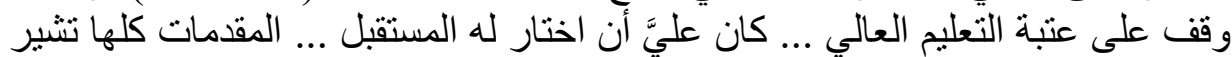

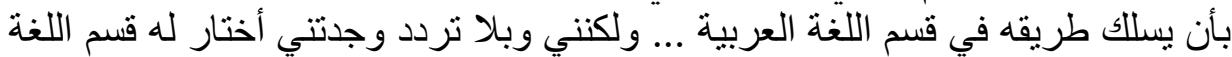

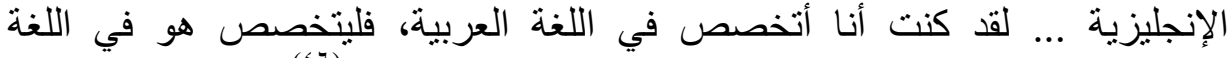

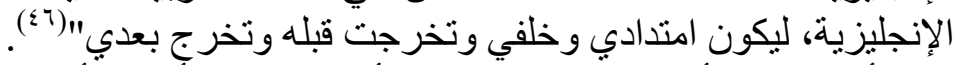

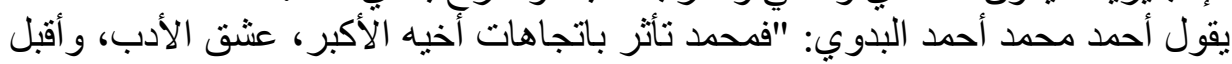

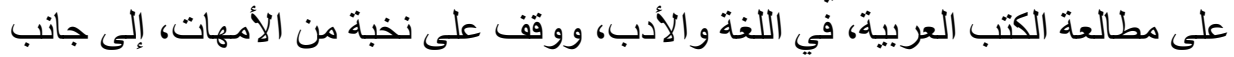

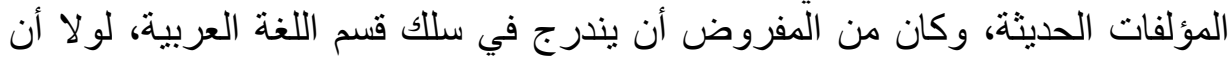

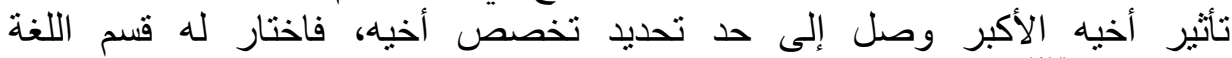

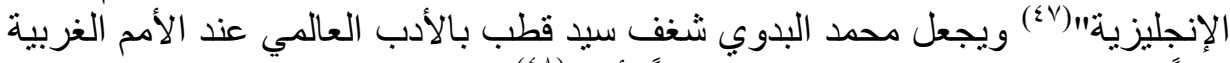

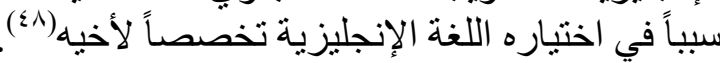

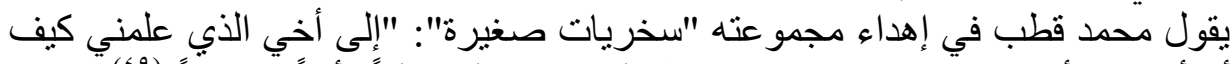

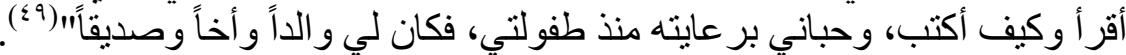

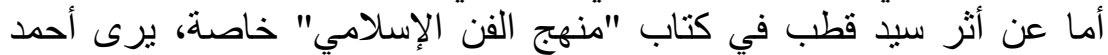

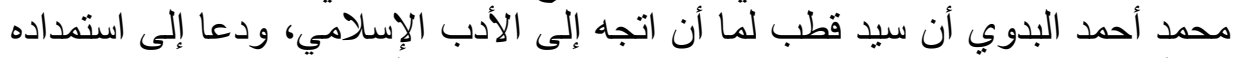

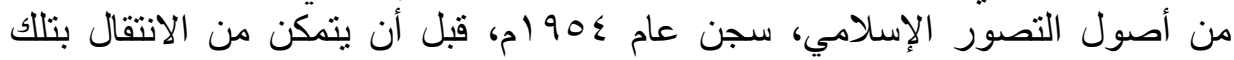

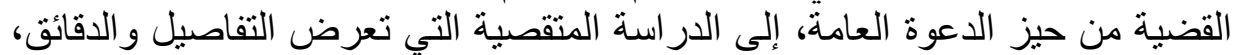

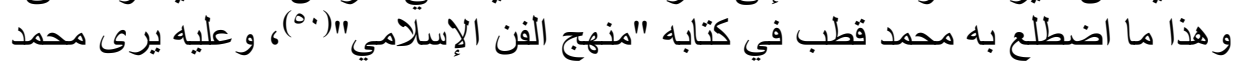
البدوي أن فكرة الكتاب بدأها سيد قطب من قبل، ثم أتمها أخيه محمد من بعد، مستدلاً

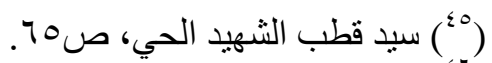

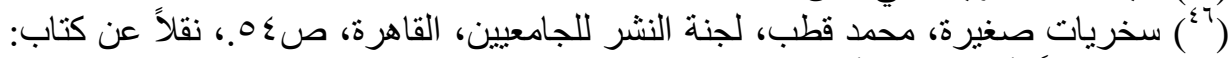

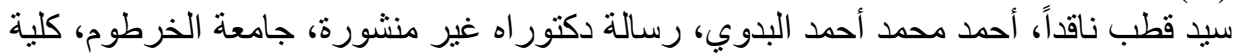

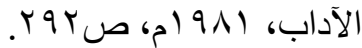

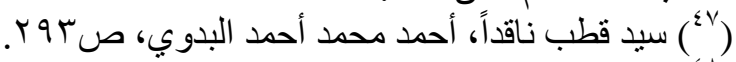

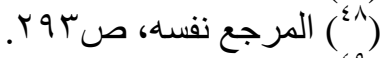

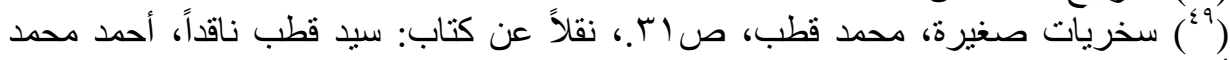

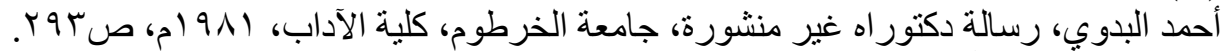

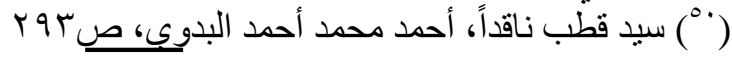
111 


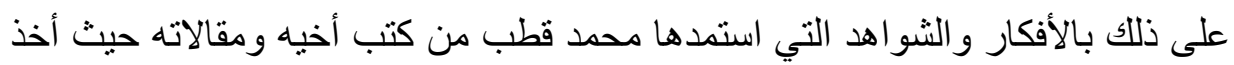

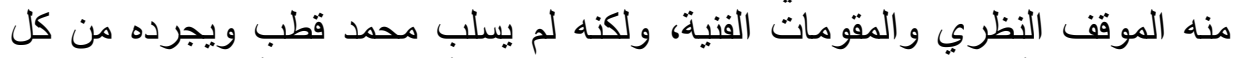

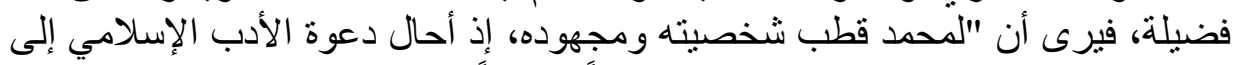

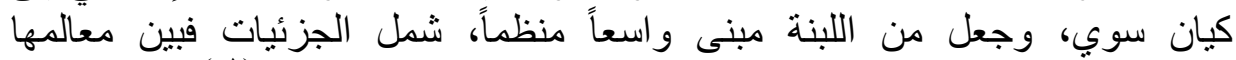

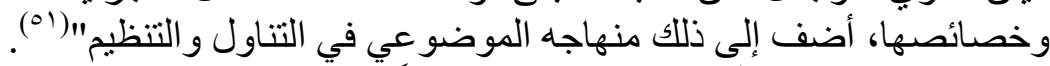

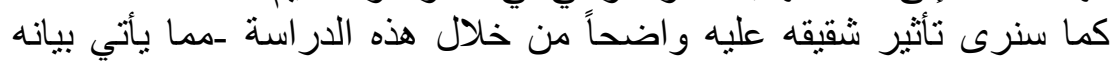

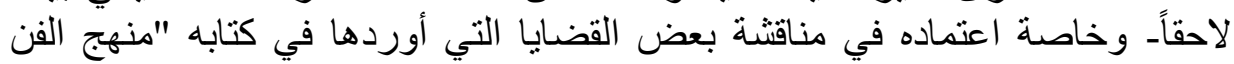

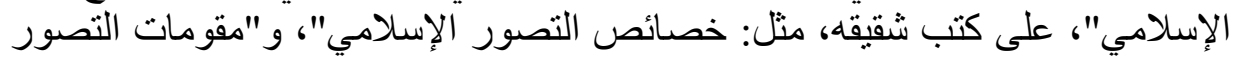
الإسلامي"، و "في ظلال الإدي القرآن الكريم"، و "التصوير الفني في القرآن الكريم" و وغير ها.

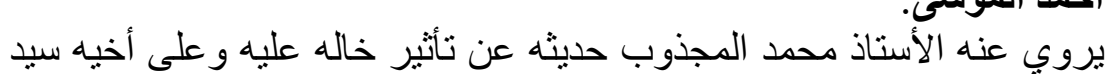

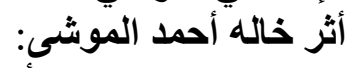

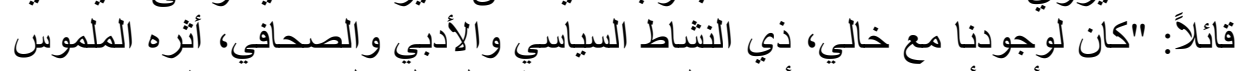

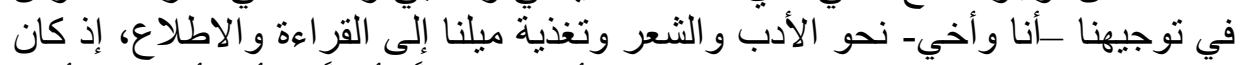

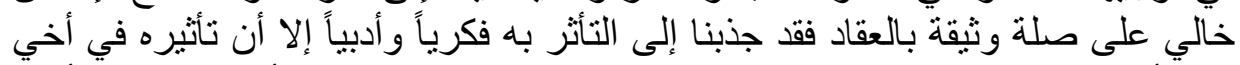

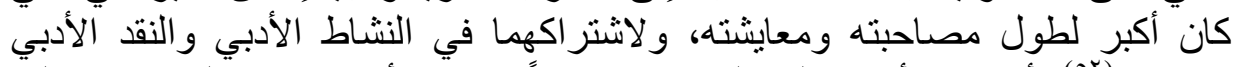

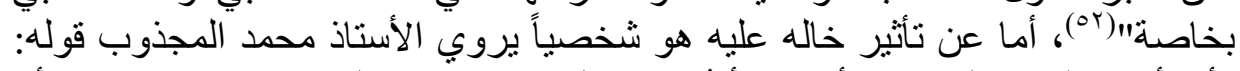

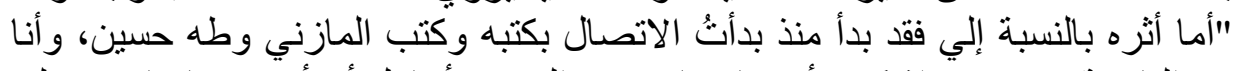

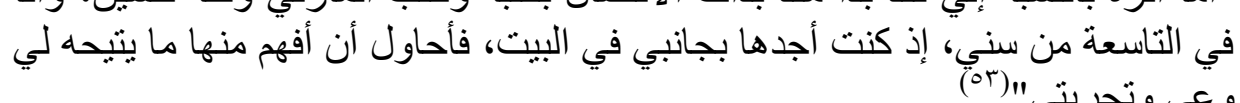

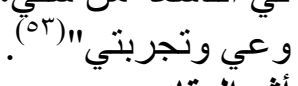

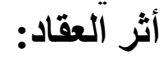

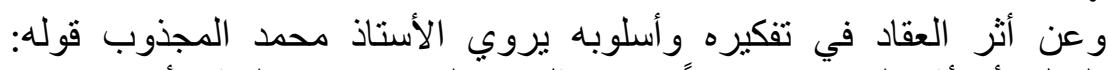

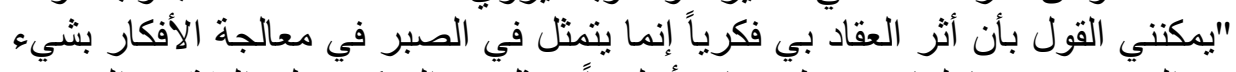

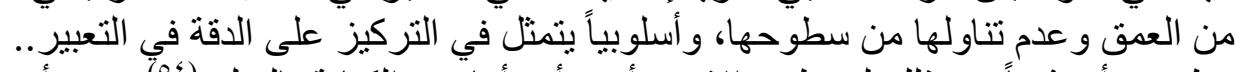

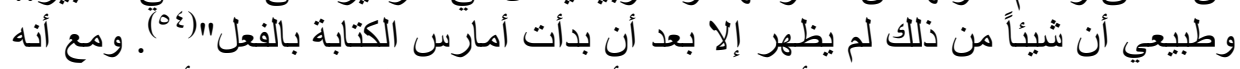

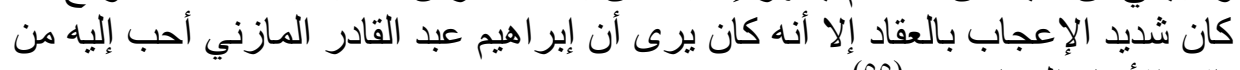
باقي الأدباء المعاصرين (00).

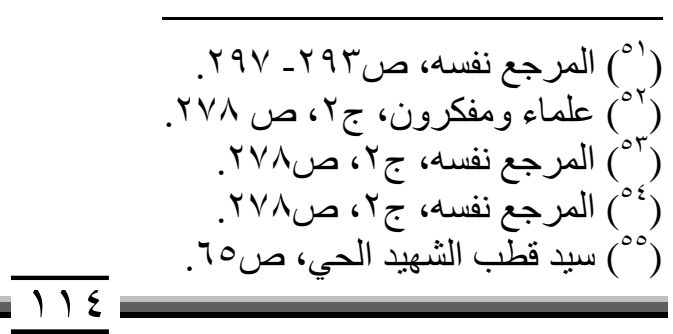




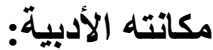

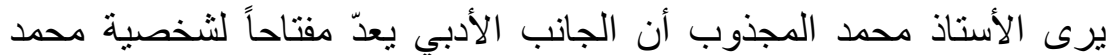

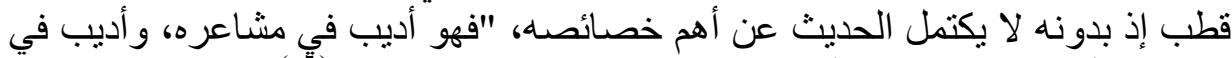

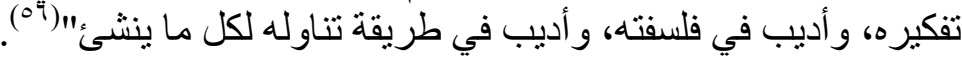

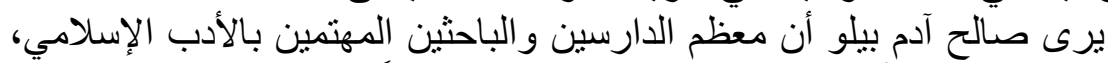

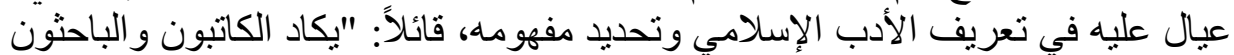

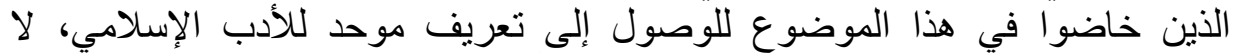

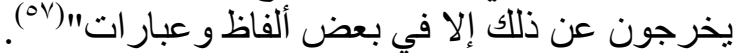

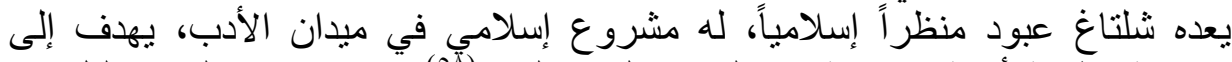

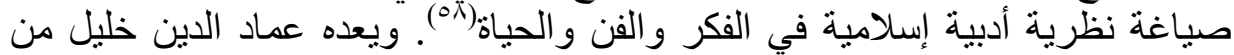

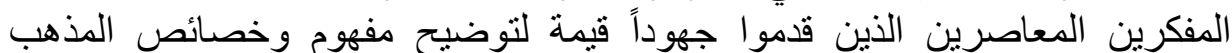

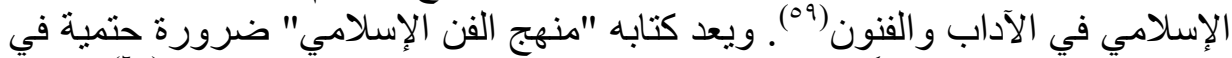

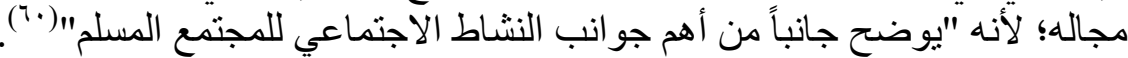

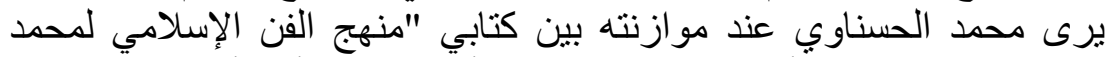
قطب، والإسلامية والمذاهب الأدبية لنجيب الكبلاني" أن الكتاب الأول أسبق النيّ من الناحية

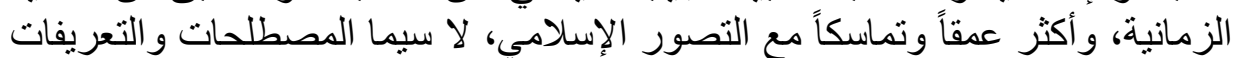

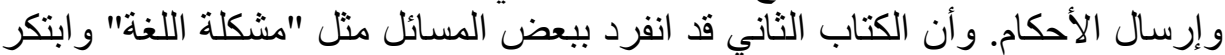

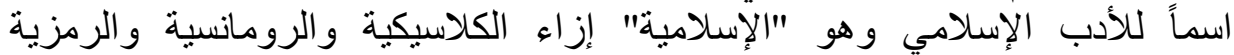

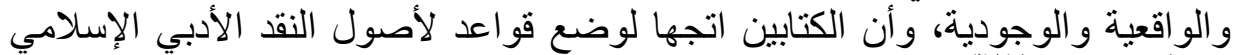

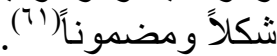
يرى نجيب الكيلاني أن كتاب منهج الفن الإسلامي ملأ فراغاً هائلاً في

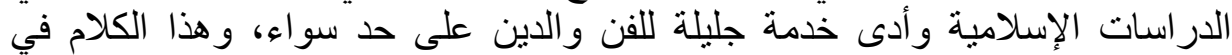
ظاهره المدح وفي باطنه الانتقاص من قيمة الكتاب؛ وذللك لأن نجيباً يزعم أن النجاء الجانب

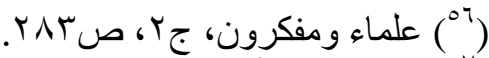

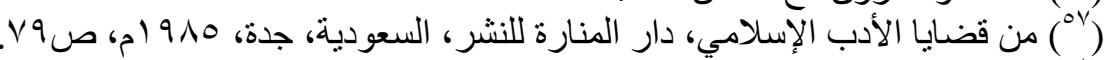

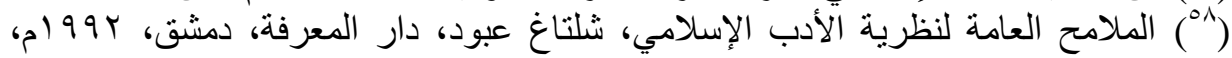
rV

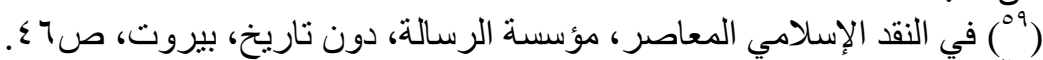

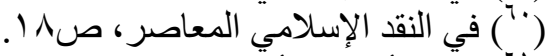

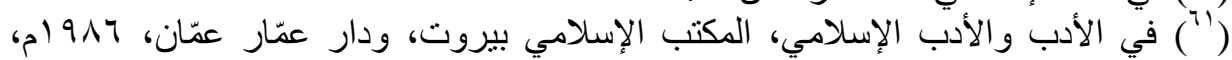


الأكبر في هذا الكتاب كان ديناً أكثر منه فناً(r). ولعلّ الذي جعله يذهب إلى ذلك كثرة

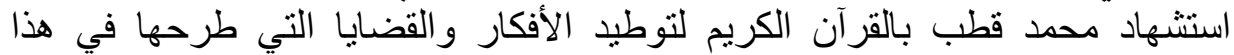

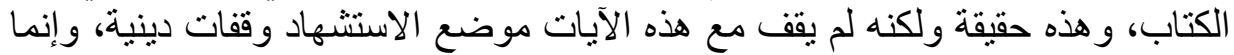
كانت وقفاته وقفات أدبية شائقة في محاولة منه لاستيحاء طرق الأبات الأداء وفنونه من القر آن

يظهر من خلال ما تقدم أن محمد قطب ركن أساس من أركان الأدب و النقد الكريم.

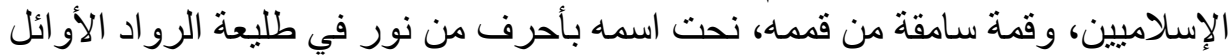

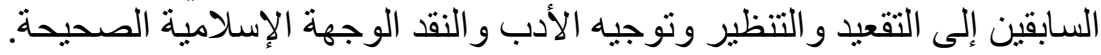

له أكثر من ثناثين مؤلفاً غاية في الأهمية تؤسس للفكر الإسلامي المعاصر من

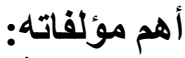

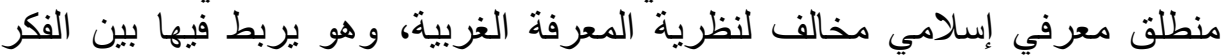

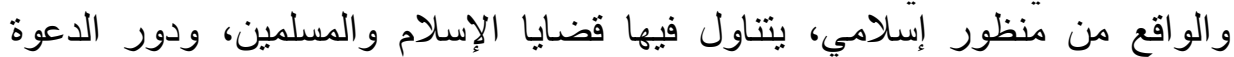

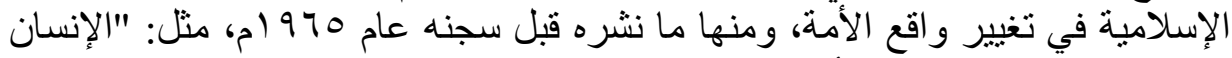

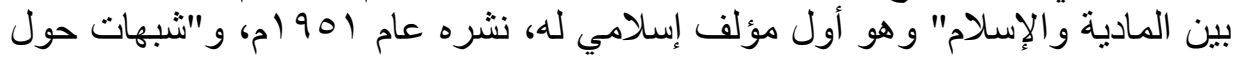

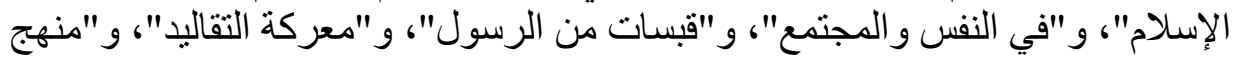

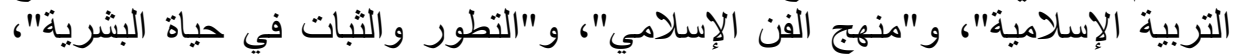

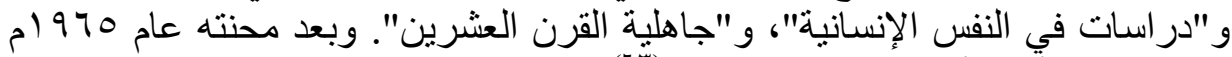

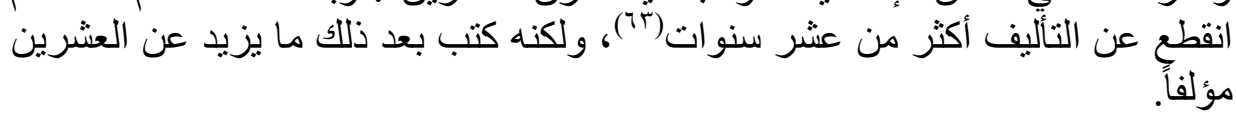
يرى محمد قطب أن أفضل مؤلفاته وأحبها إليه كتابه (الإنسان بين المادية

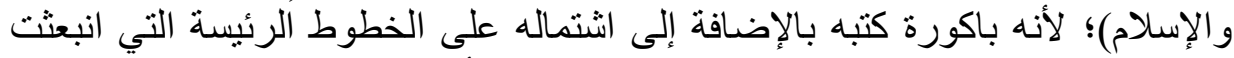

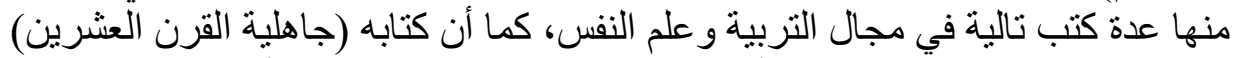

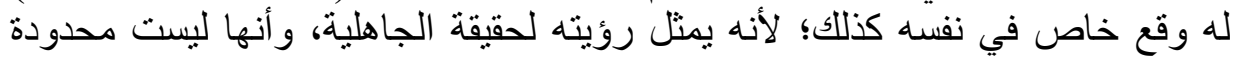

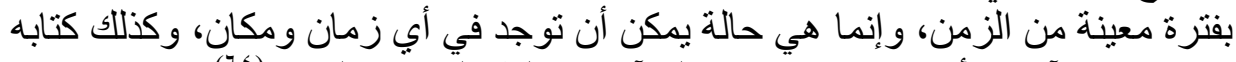

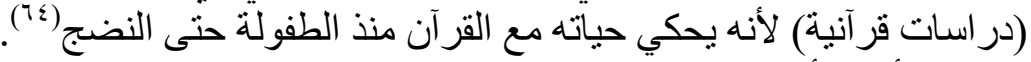

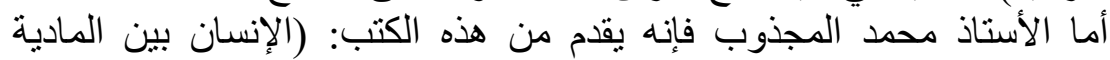
والإسلام) و(ومنهج التربية الإسلامية) و(منهج الفن الإسلامي) و(التطور والثنان لثنات في الإنية

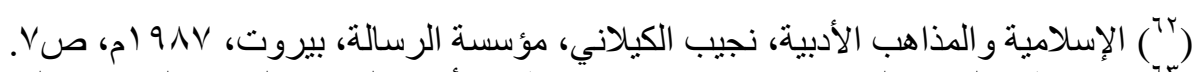

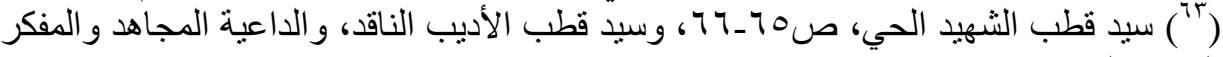

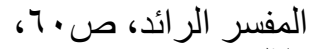

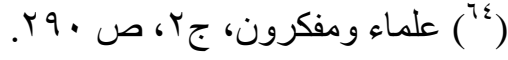




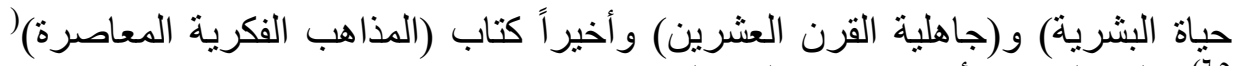

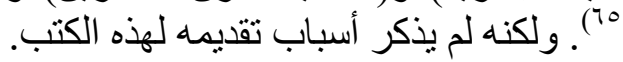

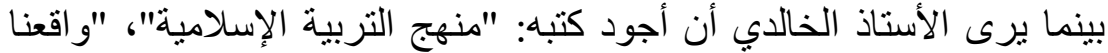

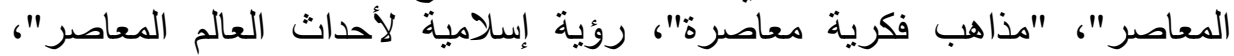

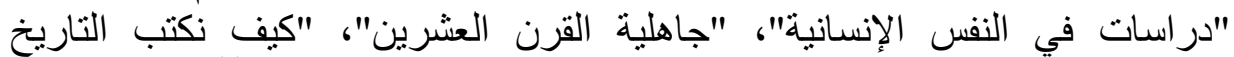

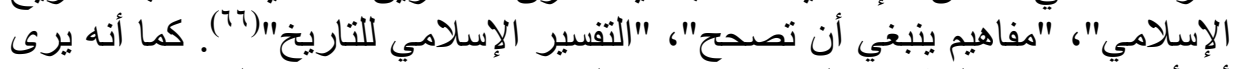

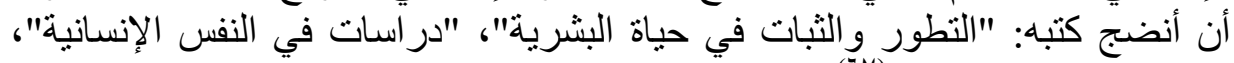

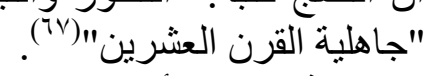
جهوده في النقد الأدبي الإسلامي:

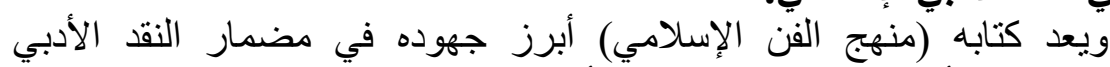

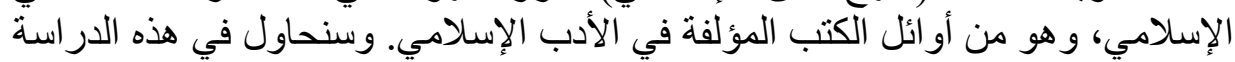

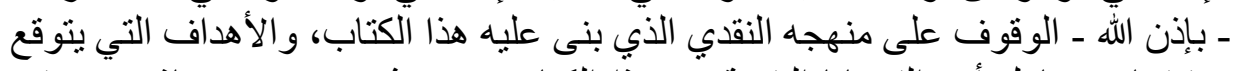

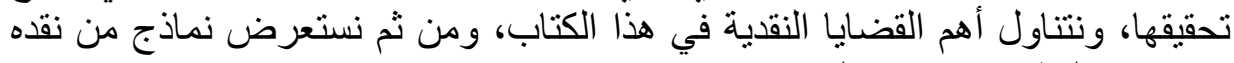
الإسلامي التطبيقي في هذا الكتاب.

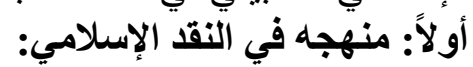

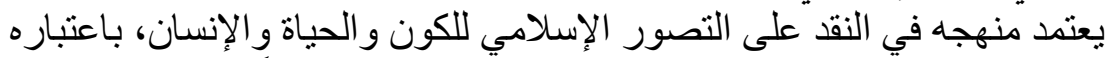

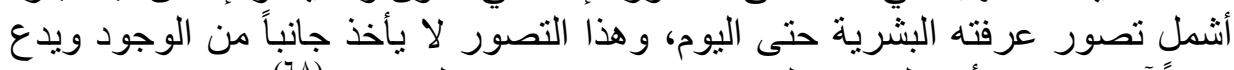

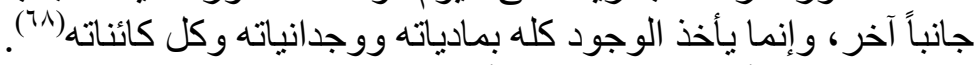

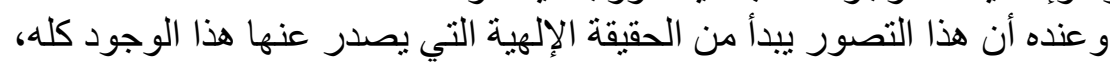

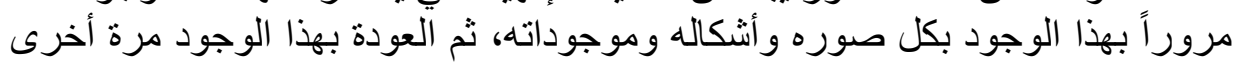

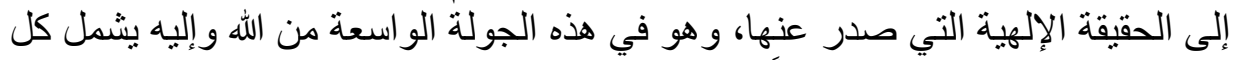

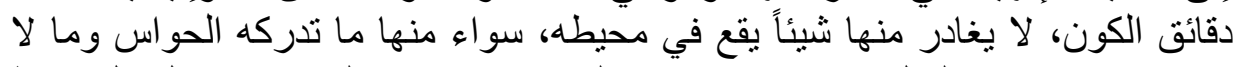

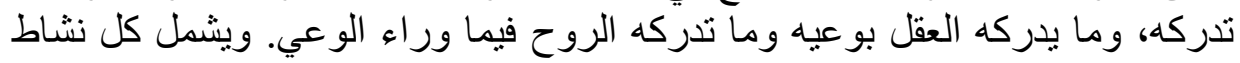

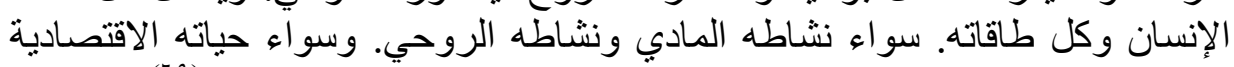

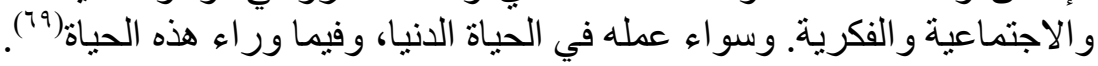
وقد سبقه إلى هذا المنهج شقيقه سيد قطب في في كتابه المتميز (خصائص التصاء التصور

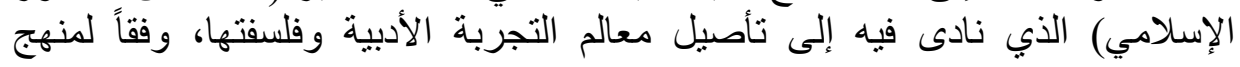

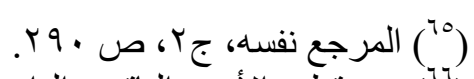

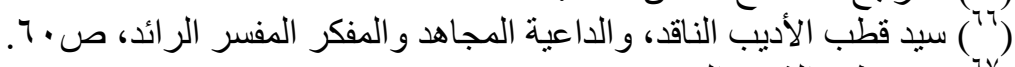
(N)

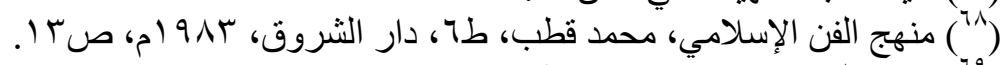

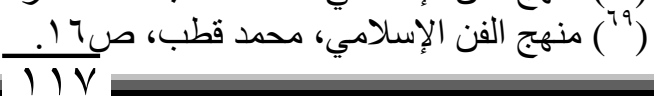




\section{د. حسّان بشَير حسّان حامل}

خصائص التصور الإسلامي الذي يقوم عنده على سبع نقاط هي: (الربانية، والثبات،

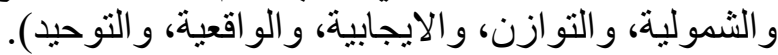

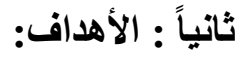

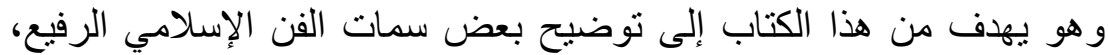

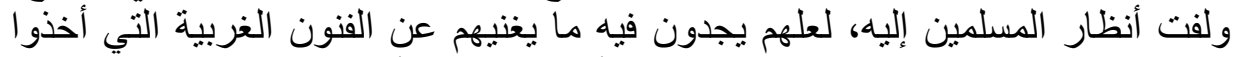

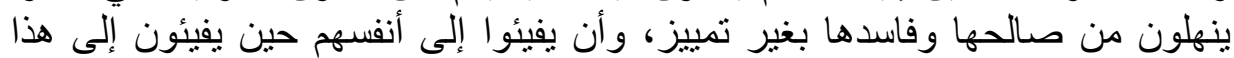

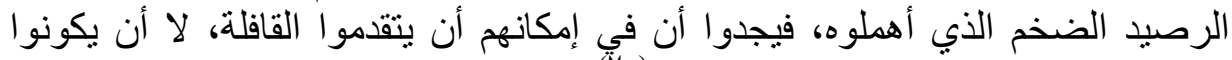

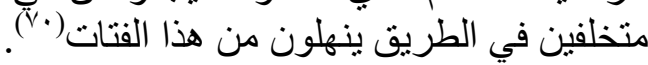

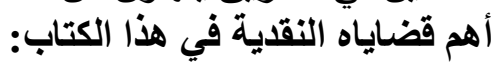
اشتمل كتابه "منهج الفن الإسلامي" عذابـ على عدد من القضايا النقدية نذكر منها ما

ا ـ العلاقة بين الإسلام والفن:

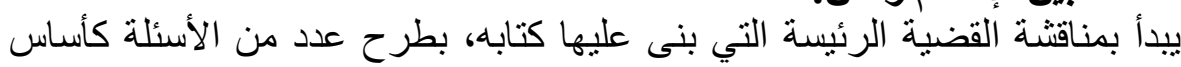

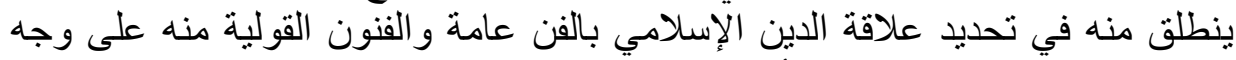

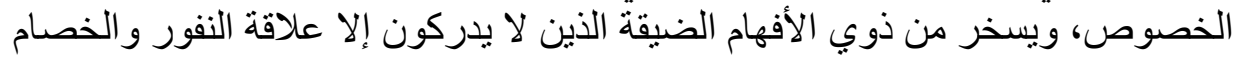

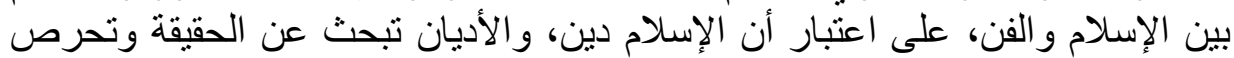

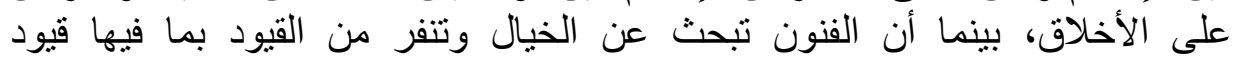

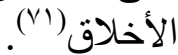
ثم بعد ذلك يشرع في تحديد العلاقة بين الفن و الدين الإسلامي، قائلاً: "إن الدين يلتقي

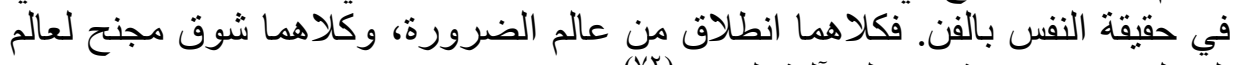

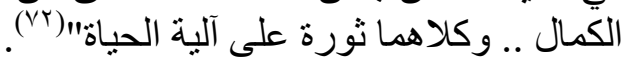

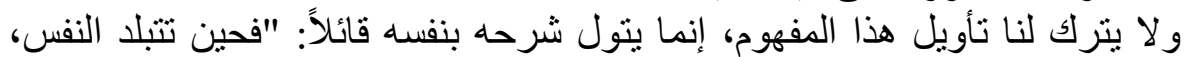

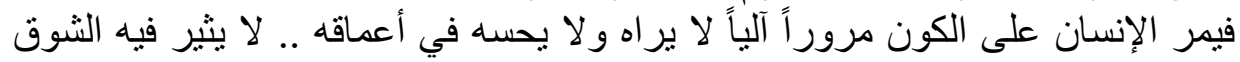

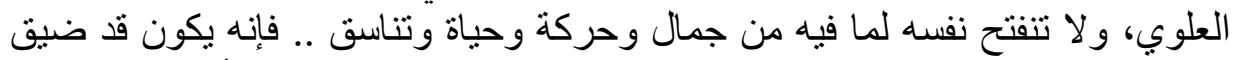

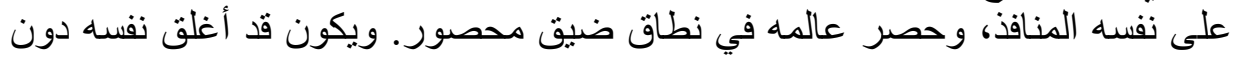
وحين تتبلد النفس ويمر الإنسان على الوجود مروراً آلياً، لا يفتح لغاياته وأهدافه والها

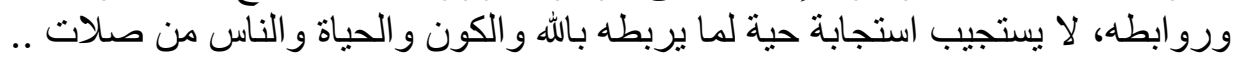

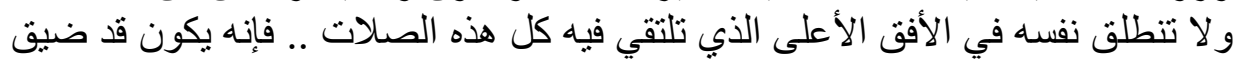

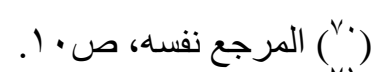

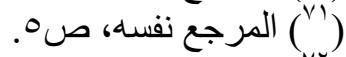

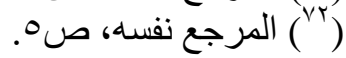




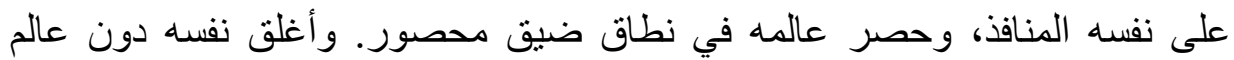
العقيدة. ومن هنا يلتقي الفن والعقيدة في أعماق النفس، كما يلتقيان في أعماق داق

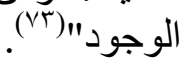

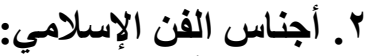

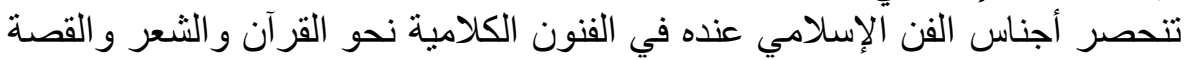
وغير ذلك، وبهذا المفهوم تخرج من دائرة الفن الإسلامي بعض الأنس الأجناس الفنية مثل

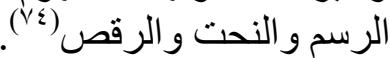

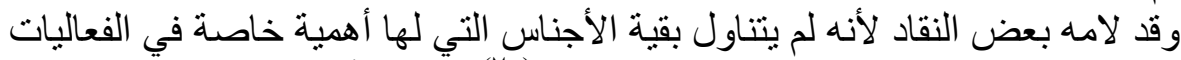

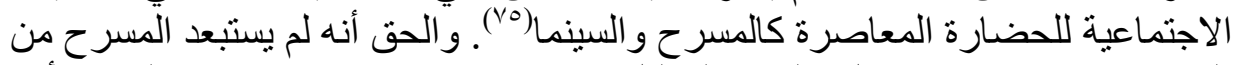

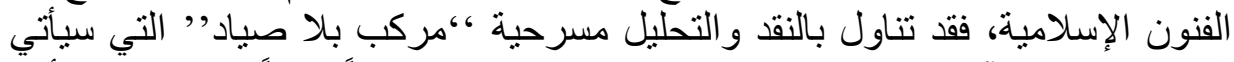

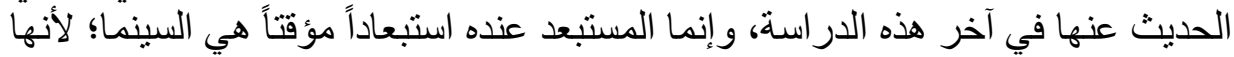

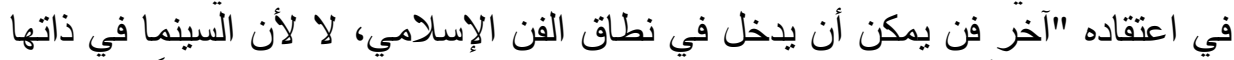

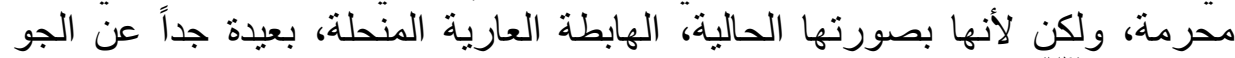

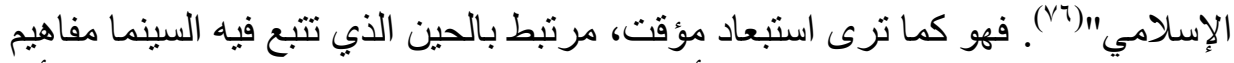

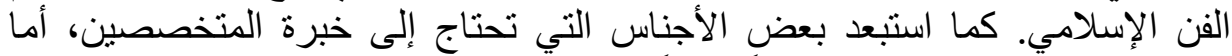

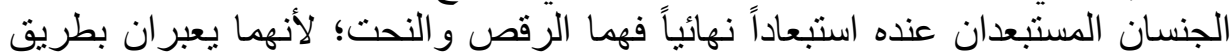

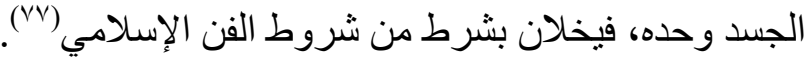

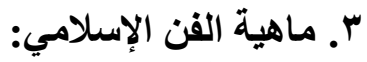

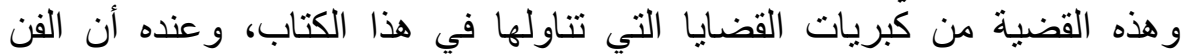

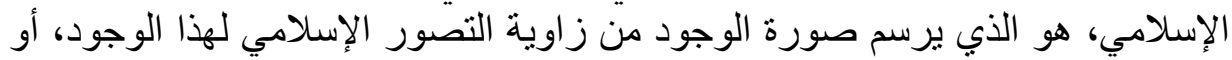

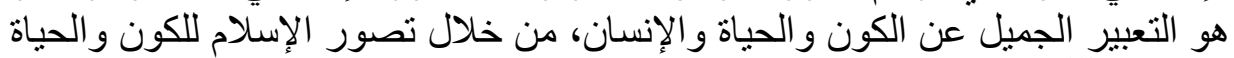

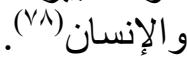

إنه لم يقصر مفهوم الأدب الإسلامي على الأدباء المسلمين فقط، ولكنه يدخل فيه كل

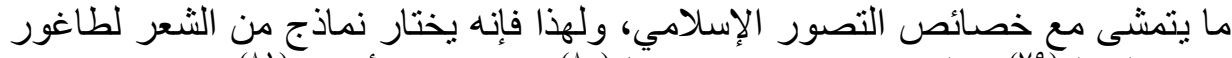

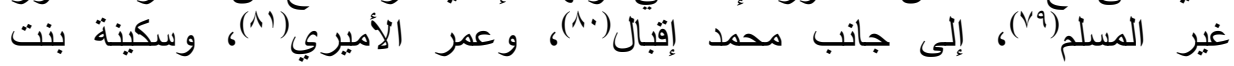

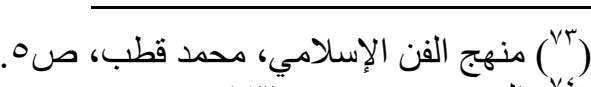

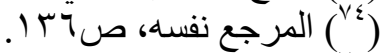

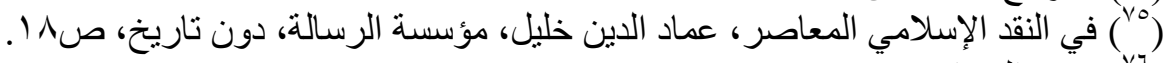

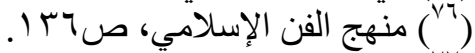

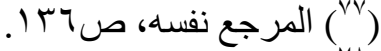

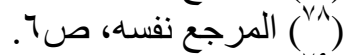

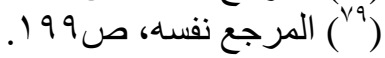




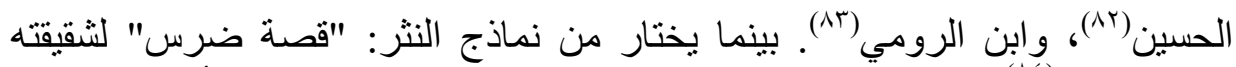

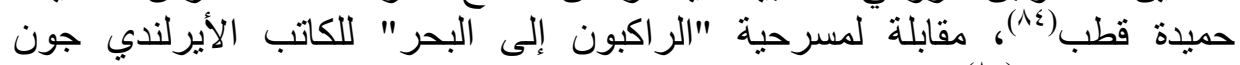

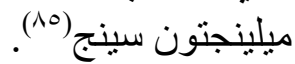

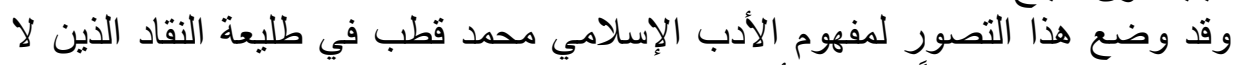

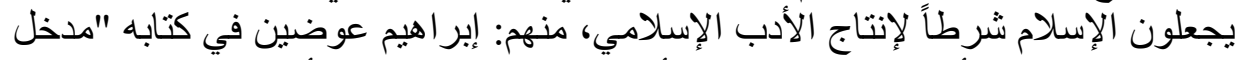

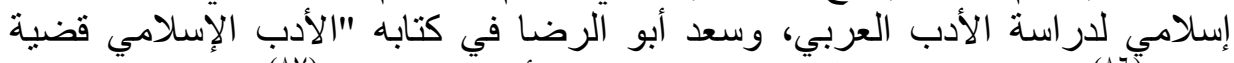

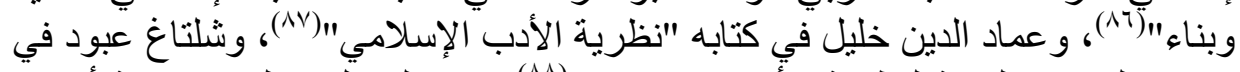

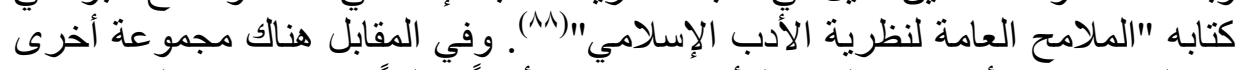

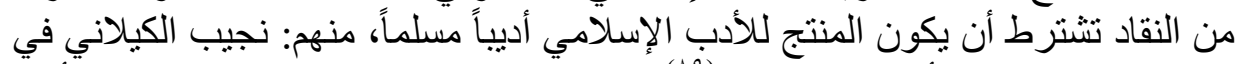

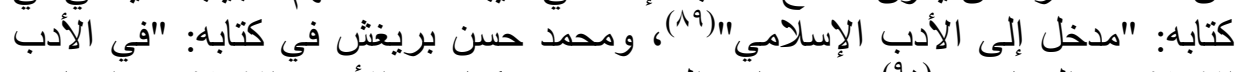

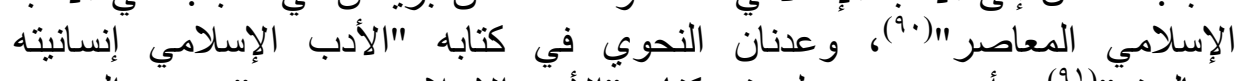

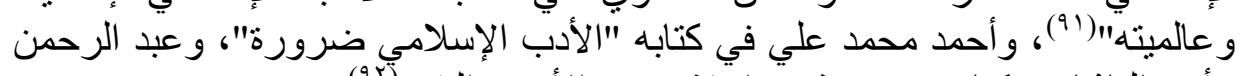

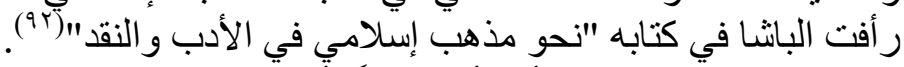

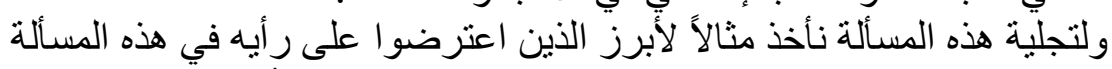

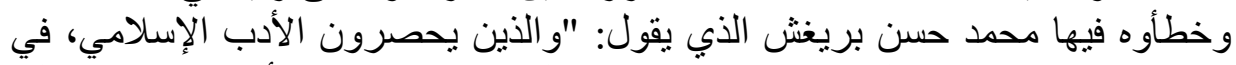

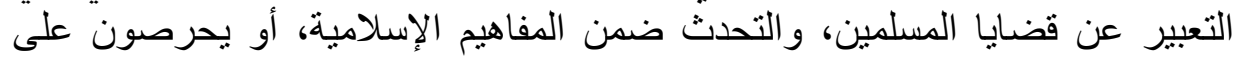

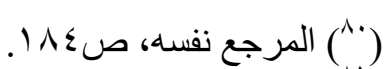

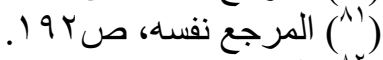

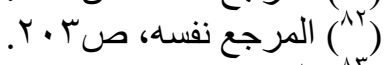

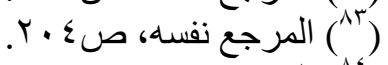

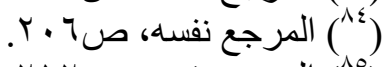

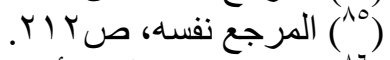

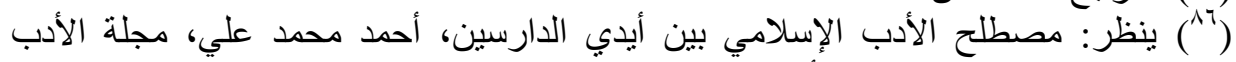

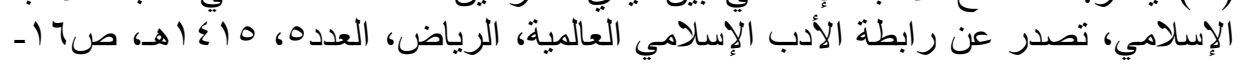

( IV

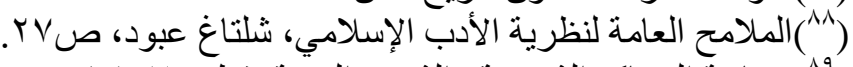

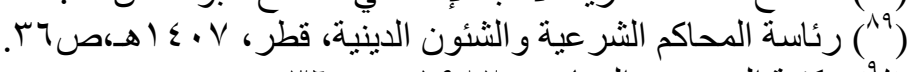

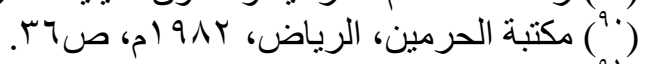

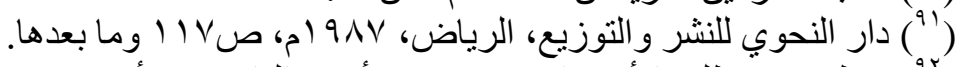

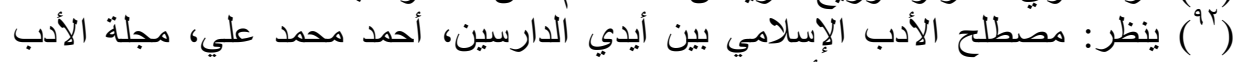

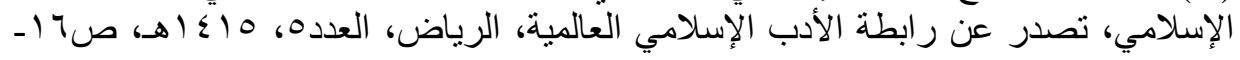




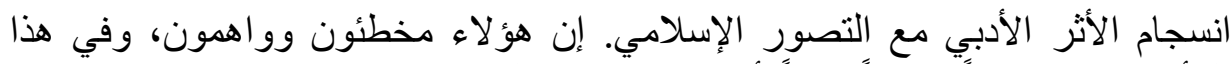

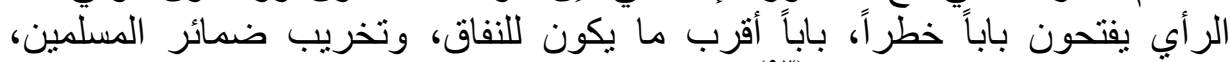

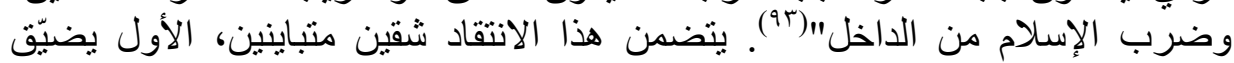

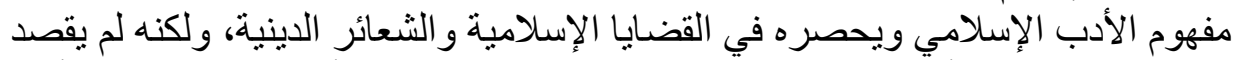

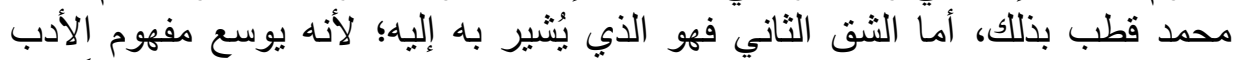

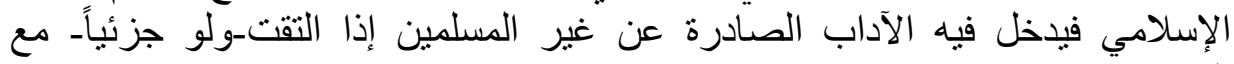

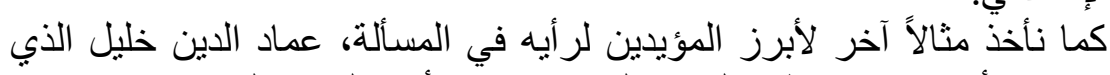

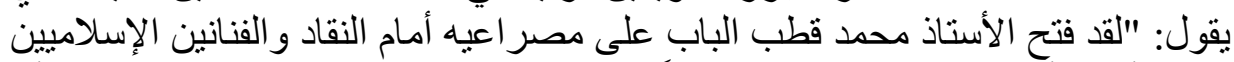

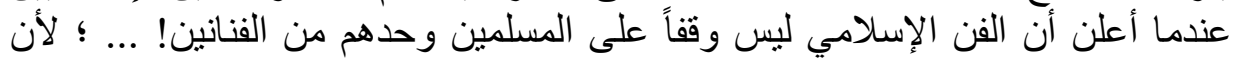

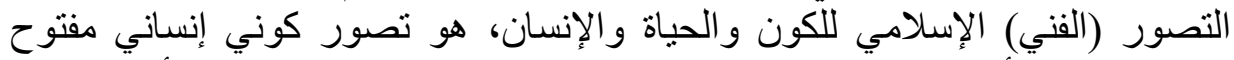

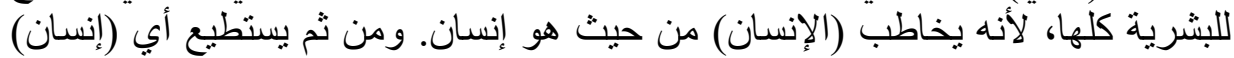

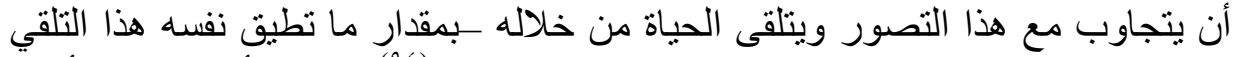

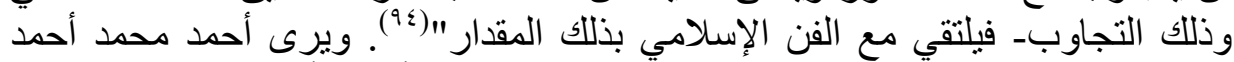

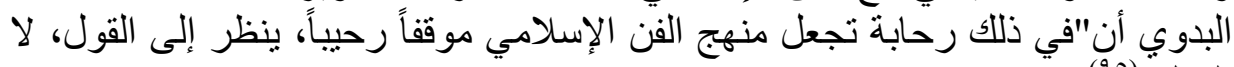
القائل" (90)

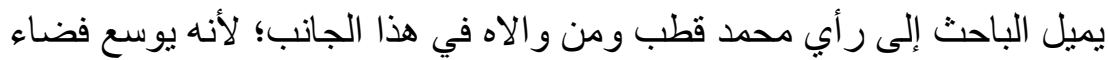

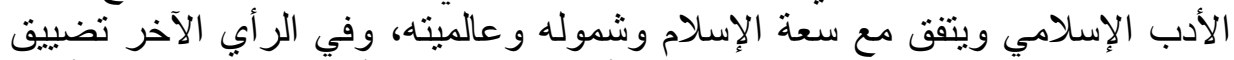

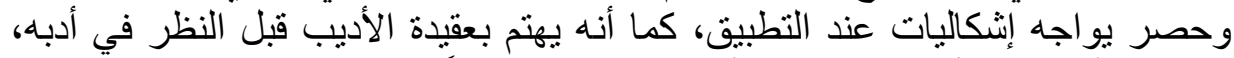

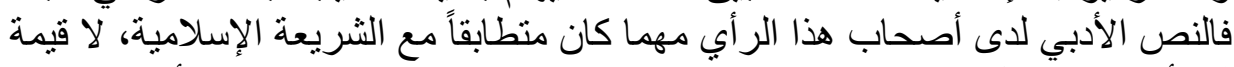

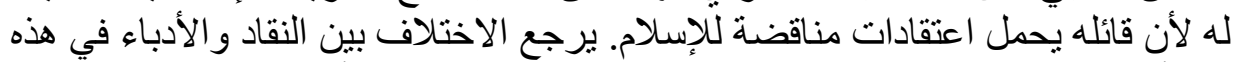

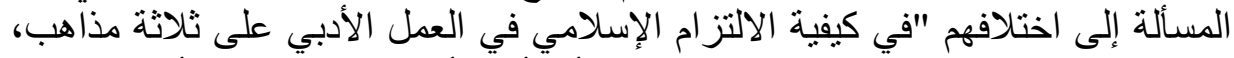

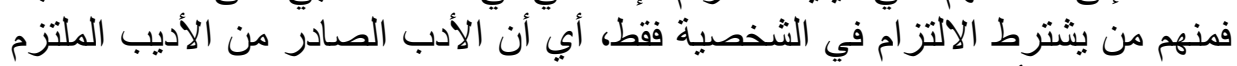

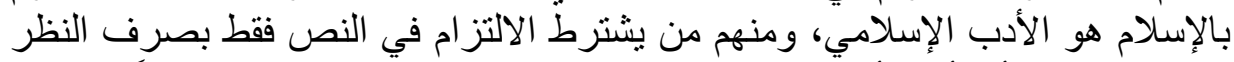

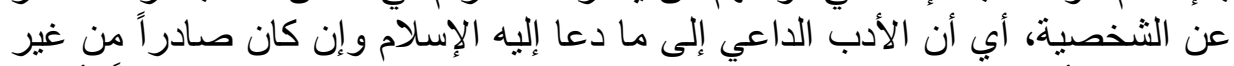

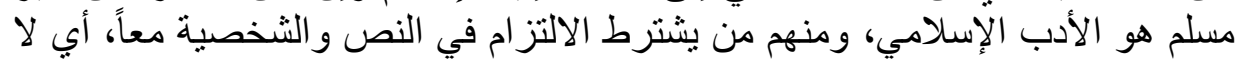

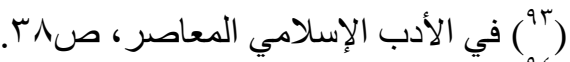

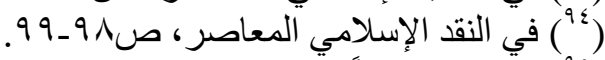

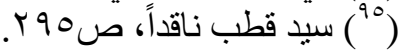




\section{د. حسّان بشير حسّان حامل}

بد أن يكون النص موظفاً في سبيل التوعية الإسلامية وصادراً من مسلم ملتزم بالإسلام

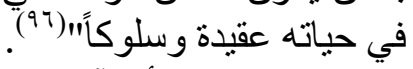

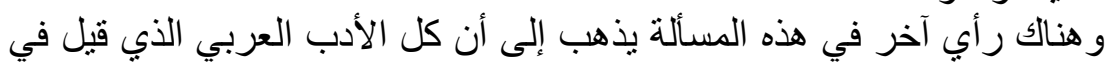

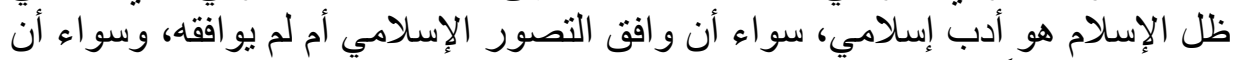

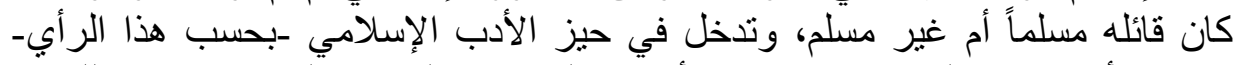

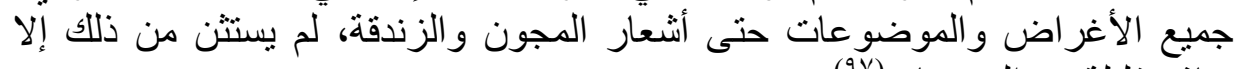

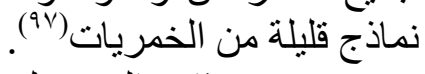

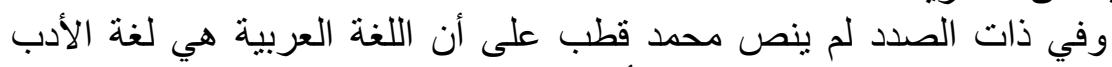

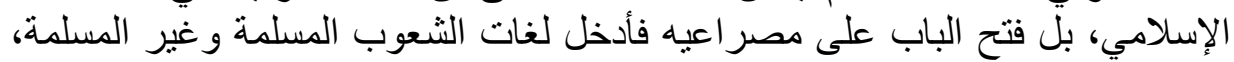

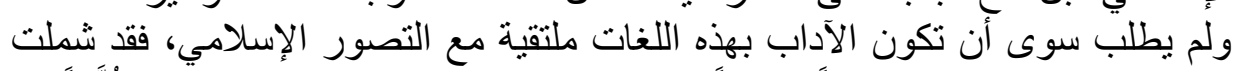

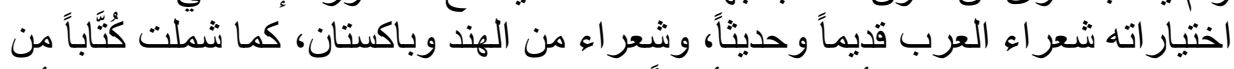

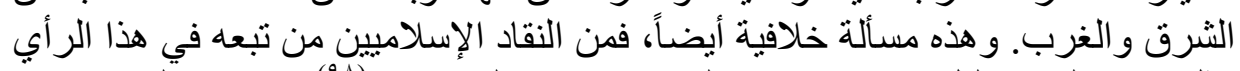

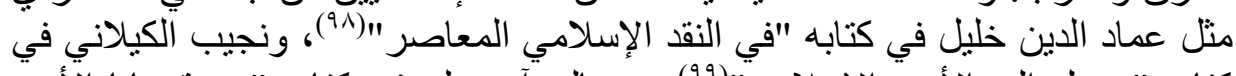

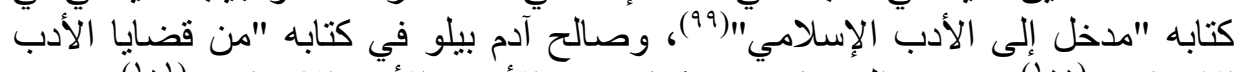

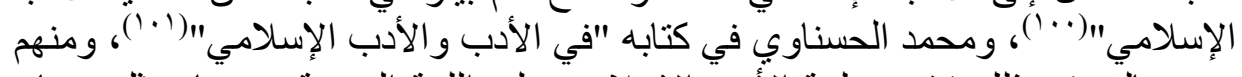
من يخالفه في ذلك فيقصر لغة الأدب الإسلامي على اللغة العربه الإبية وحدها، مثل عدنان

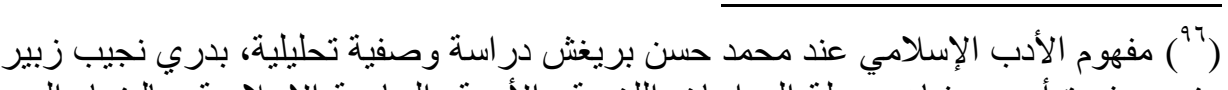

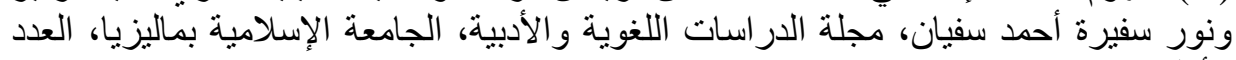

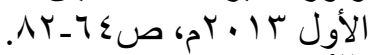

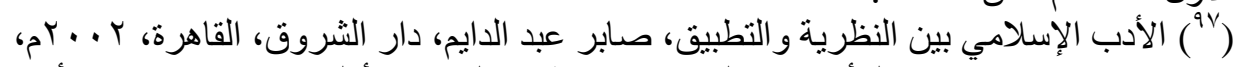

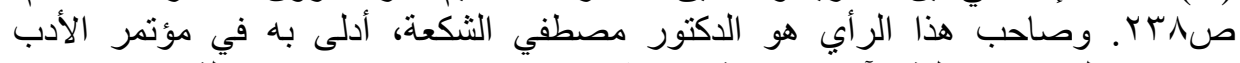

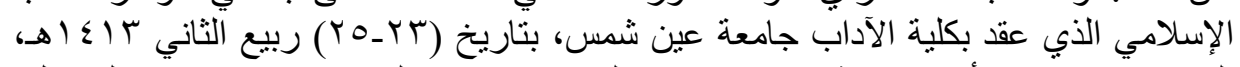

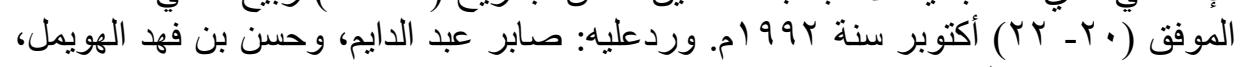
و ومحمد بن مريس الحارثي. (1) ينظر اختباره لمسرحية "مركب بلا صياد" للمسرحي الإسباني "اليخاندرو كاسونا"، ص9-7V

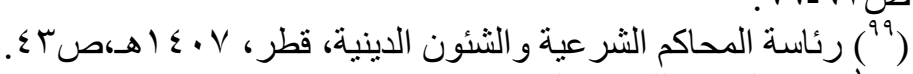

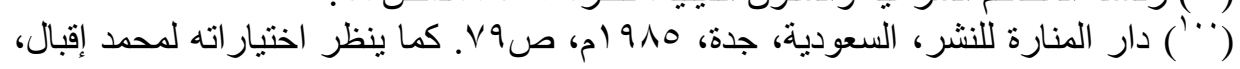

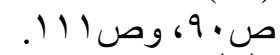

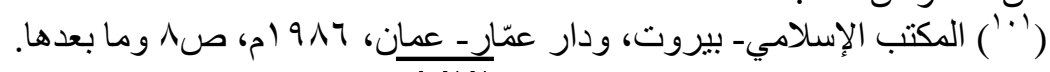


علي رضا النحوي في كتابه "الأدب الإسلامي إنسانيته و عالميته"(r.ا')، و الطاهر محمد

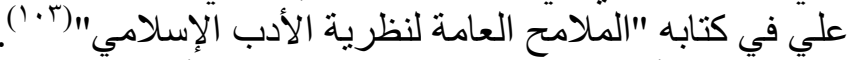

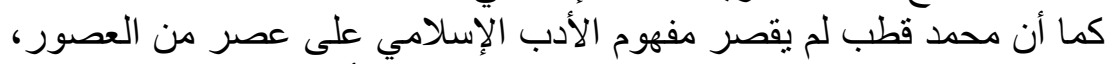

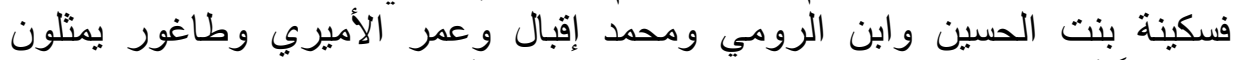

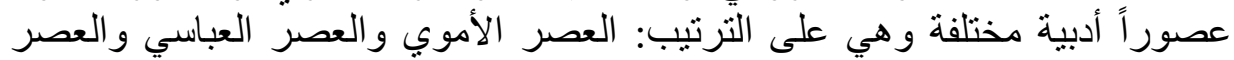

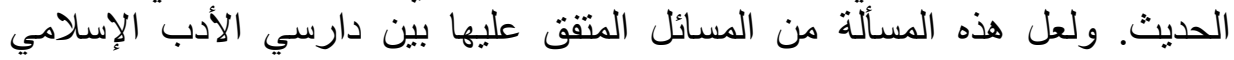

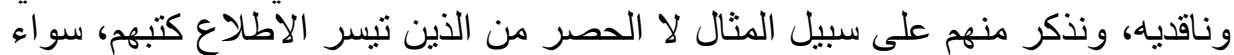

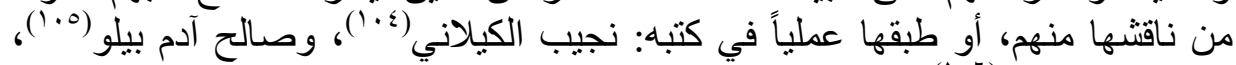

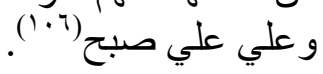

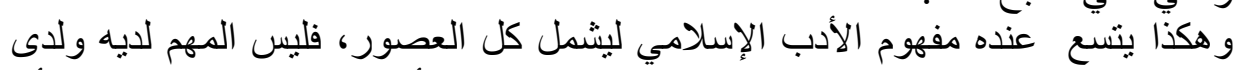

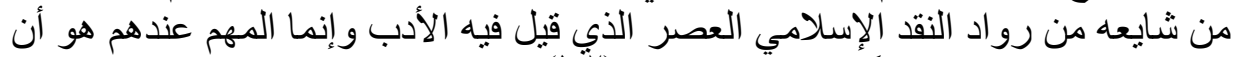

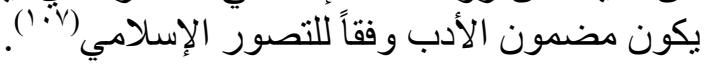

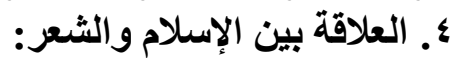

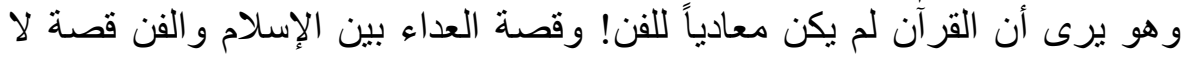

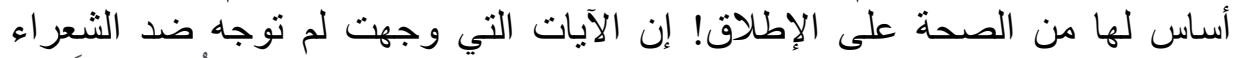

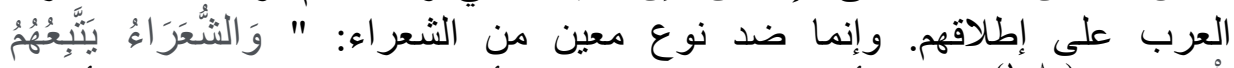

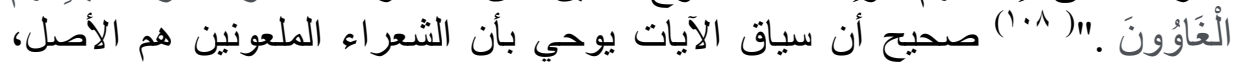

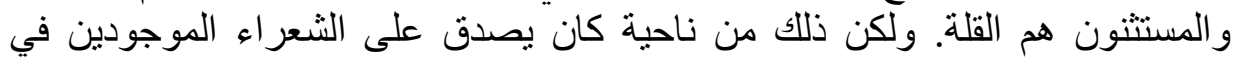

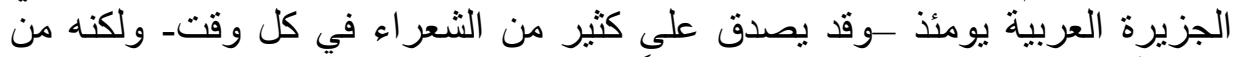

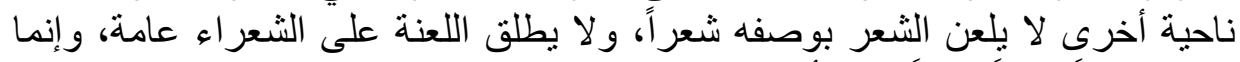

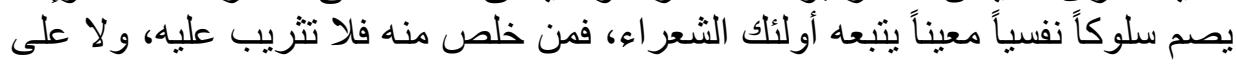
فنه الذي يعبر فيه عن مفاهيمه الإيمانية. الملعون إذن هو الكئن الكفر. والمطلوب هو الإيمان.

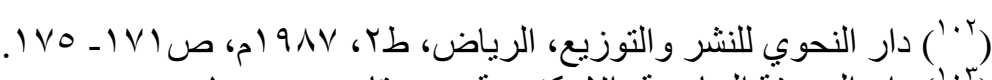

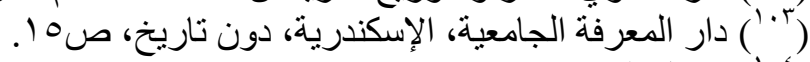

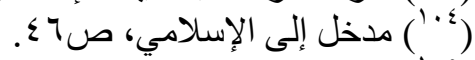

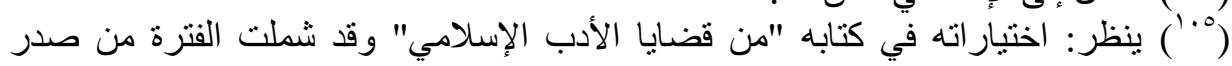
الإسلام إلى العصر الحديث.

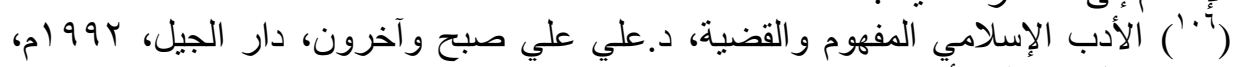

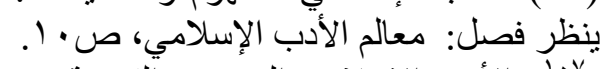

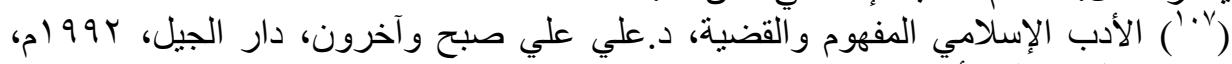

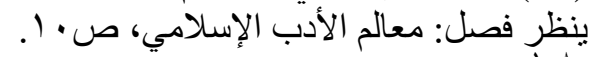
ITT

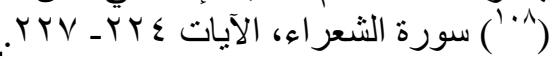


و لا على المؤمنين -حين يكونوا شعر اءـ أن يقولوا الشعر في حدود تصور هم الإيماني

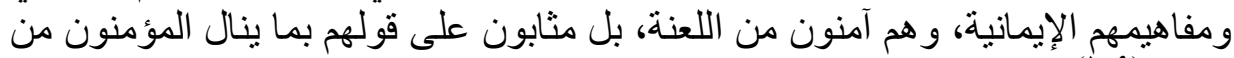

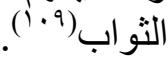

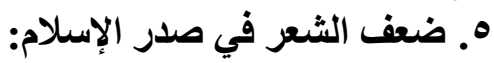

و هي من القضآيا التي تناولها النقاد الأو ائل من لان ابن إن سلام الجمحي الذي يقول:

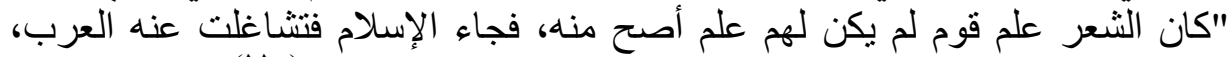

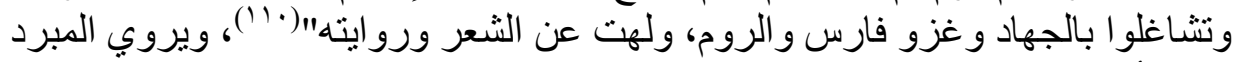

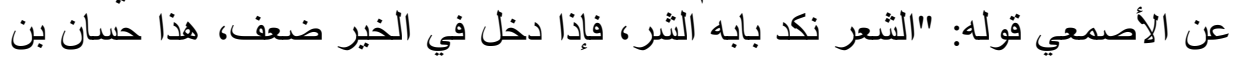

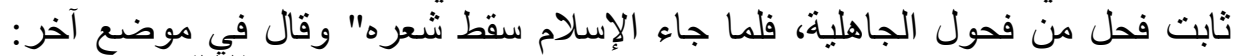

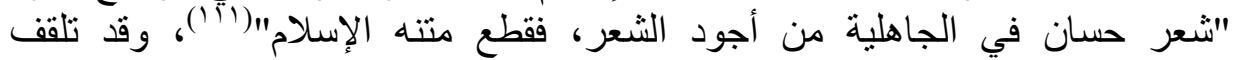

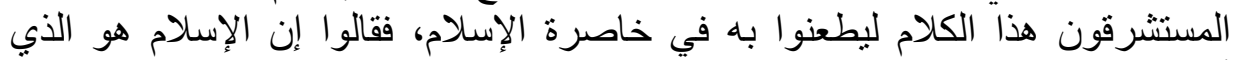

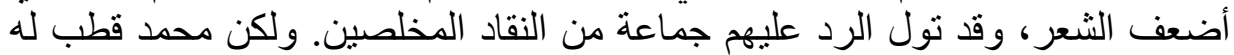

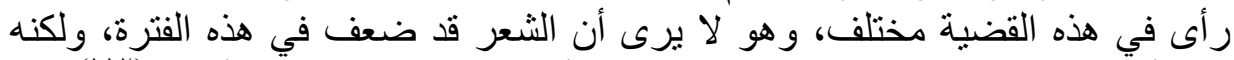

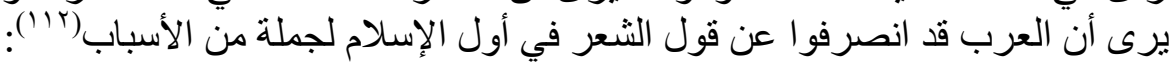

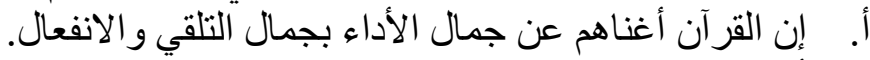

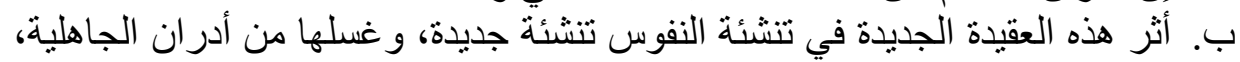

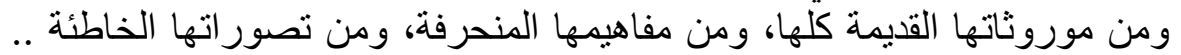

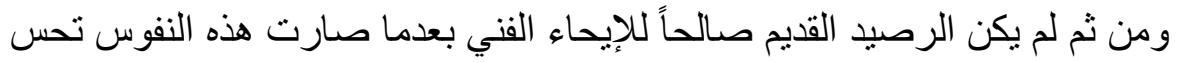

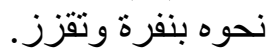

ج. إن الأغر اض بذرة التقليدية التي كان يقال فيها الشعر ، قد تغيرت من أساسها بفعل العقبدة

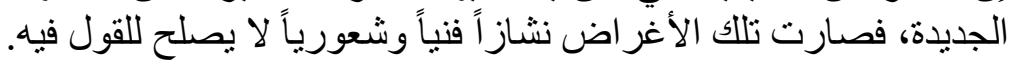

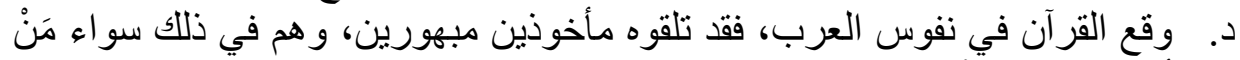

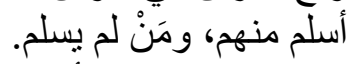

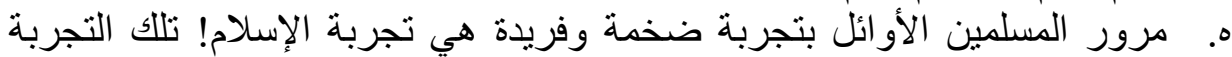

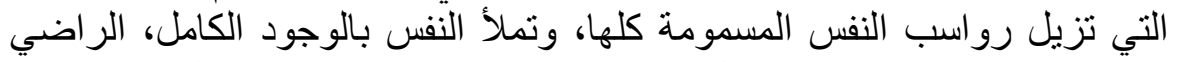
بهذا الوجود، وهي تجربة لا تقول الثعر إلا بطاقة ضخمة لان لأ تو هب لكل إنسان.

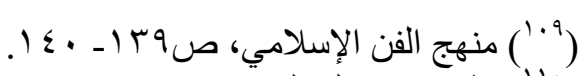
("' (") طبقات فحول الثعر اء، محمد بن سلام الجمحي، تحقيق: محمود محمد شاكر، القاهرة،

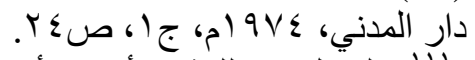
(") الكآمل في اللغة والأدب، لأبي عباس الب، المبرد، تحقيق: محمد أبو الفضل إبراهيم، دار الفكر

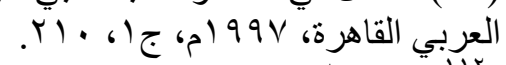


7. مفهوم الجاهلية والأدب الجاهلي:

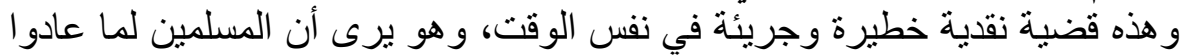

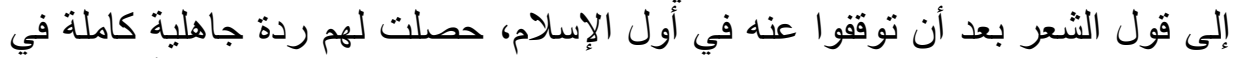

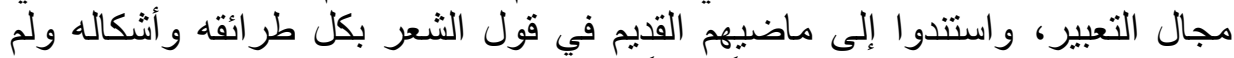

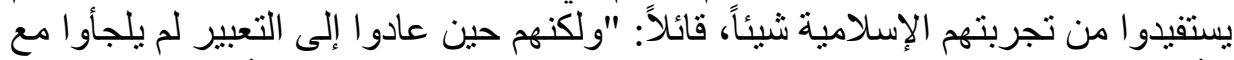

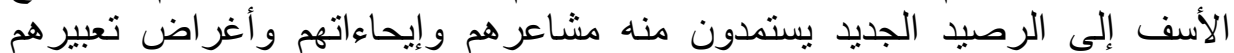

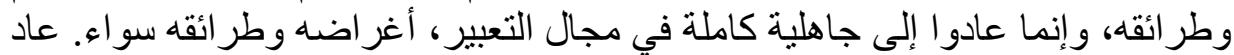

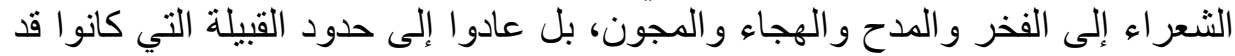

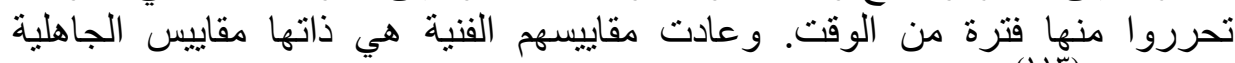

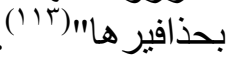

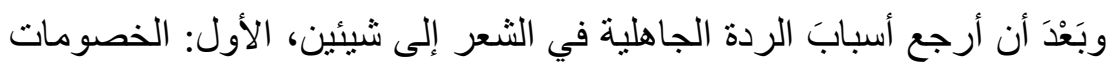

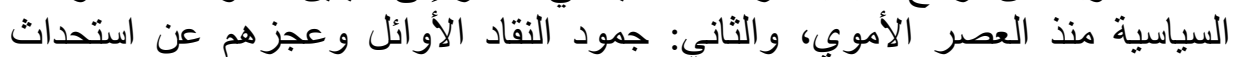

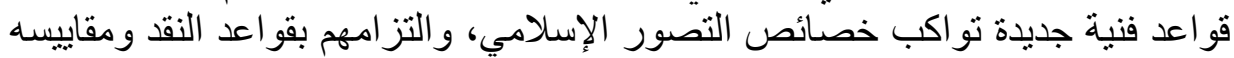

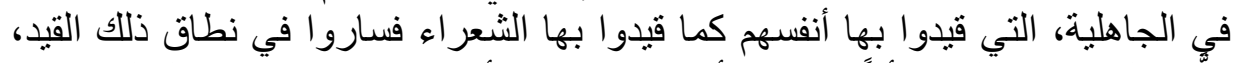

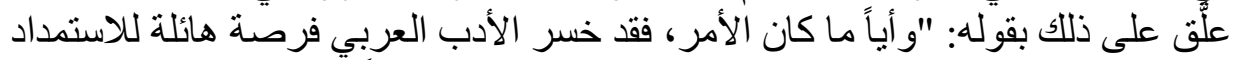

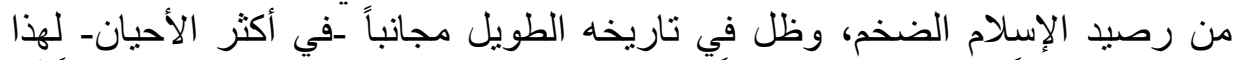

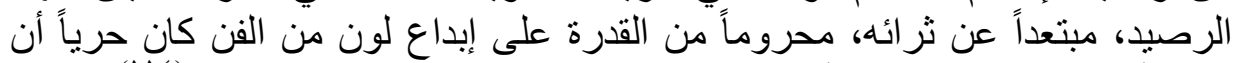

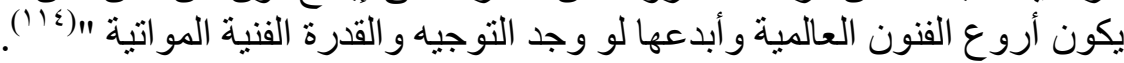

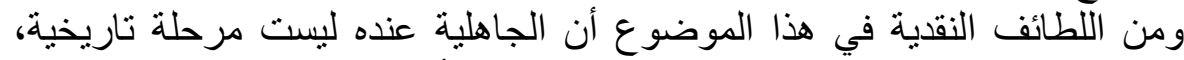

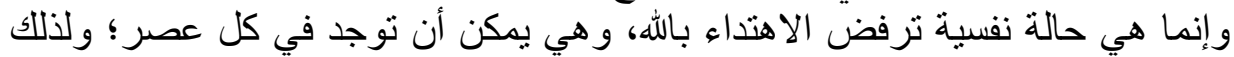

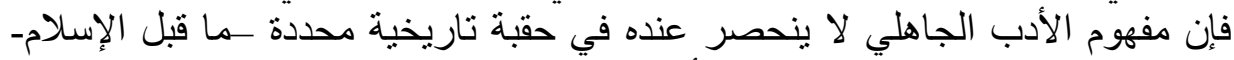

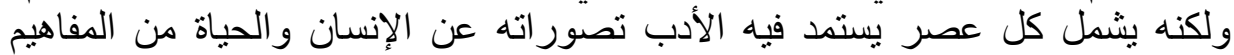

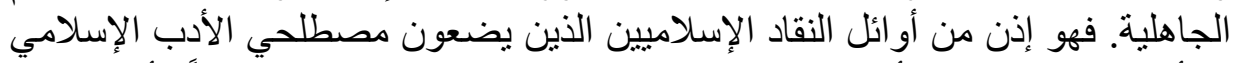

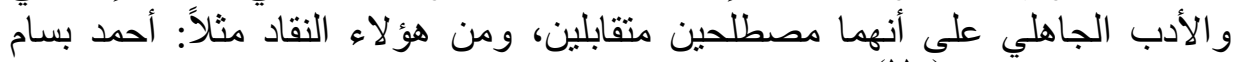
ساعي، وشلتاغ عبود (110).

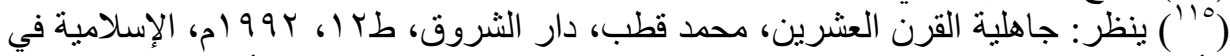

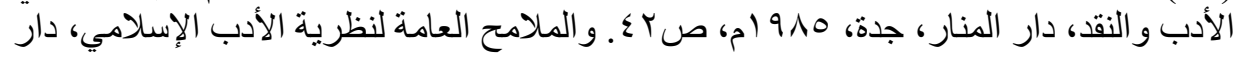




\section{V ابين الأدب الإسلامي والمذاهب الغربية:}

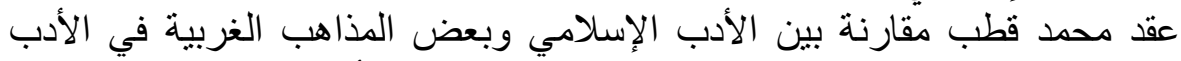

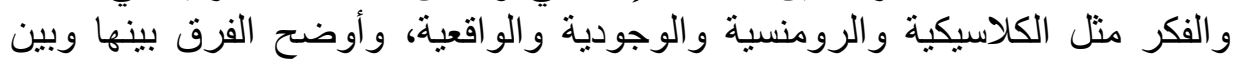

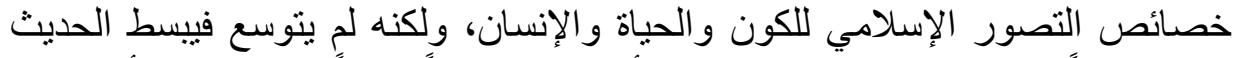

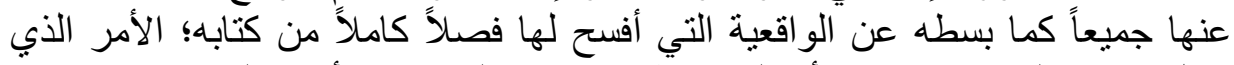

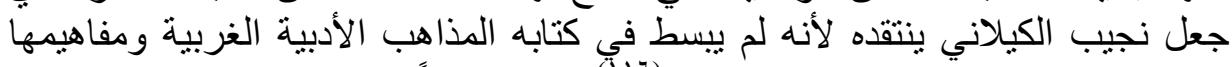

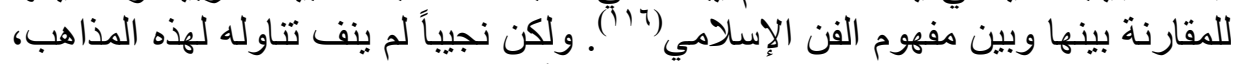

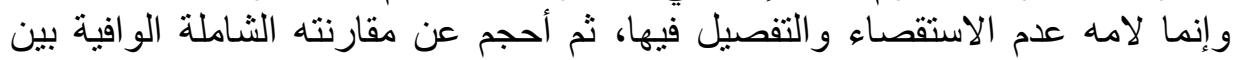

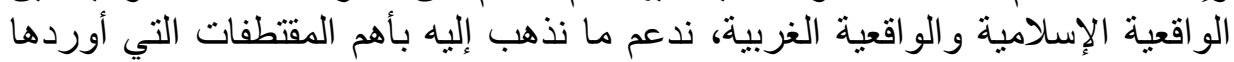

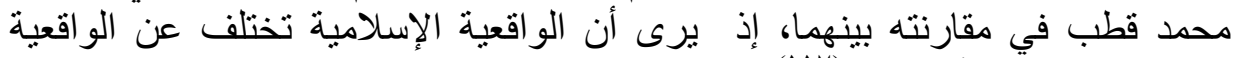

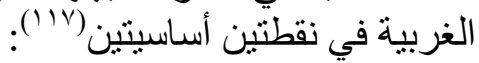

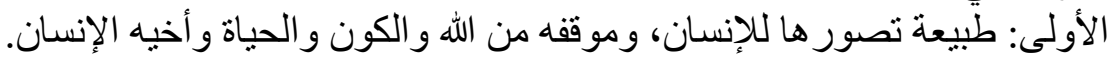

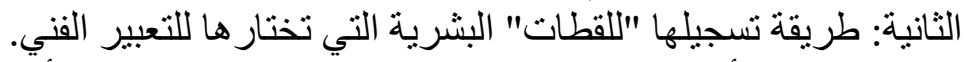

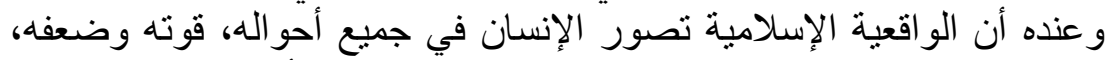

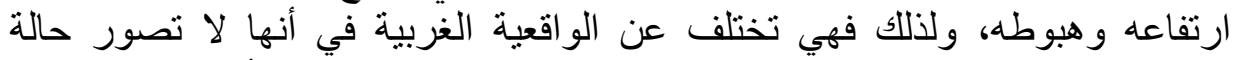

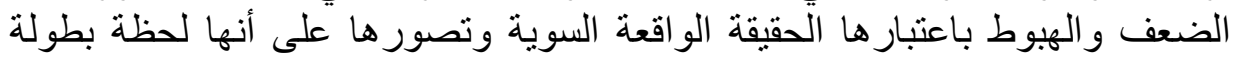

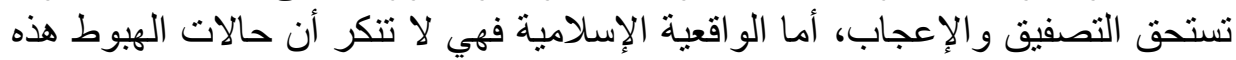

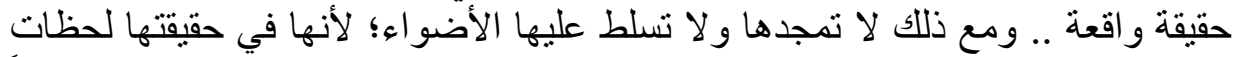

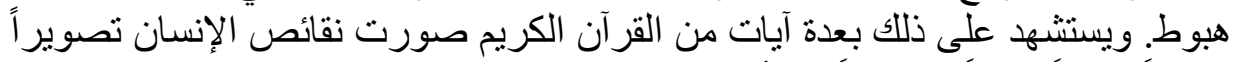

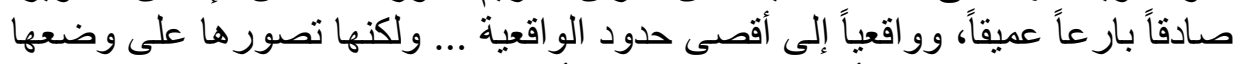
الطبيعي الحقيقي، وهي أنها نقائص ينبفي الطي أن يرتفع عليها الإنسان. و وهنا مفرق

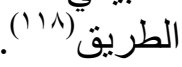

كما يرى أن الواقعية الإسلامية في نفس الوقت "لا تزعم أن الإنسان خير كله

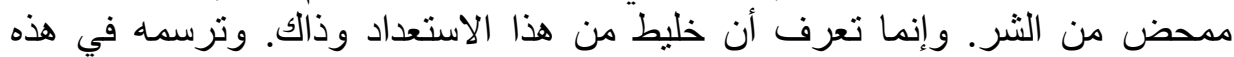

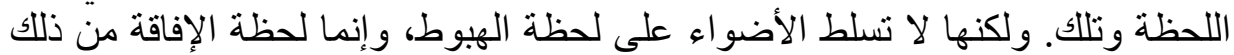
الهبوط(19).

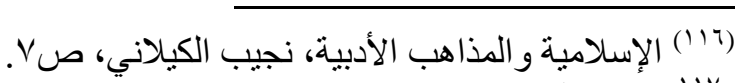

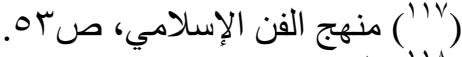

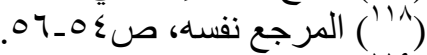

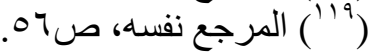




\section{نماذج من نقده التطبيقي للأدب الإسلامي:}

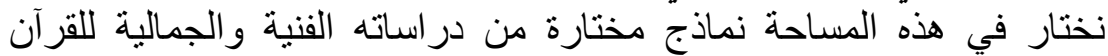

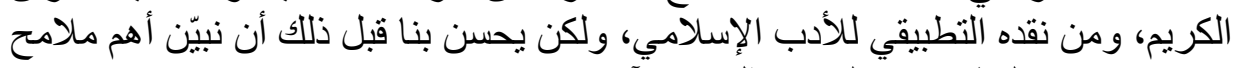

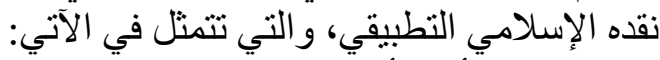

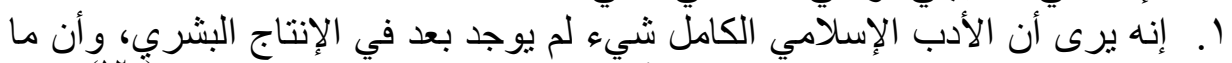

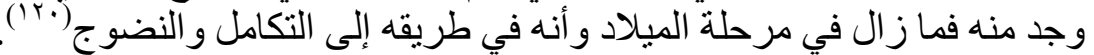

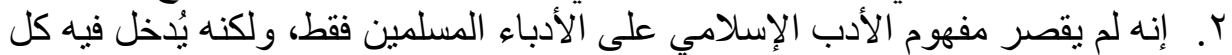
ما يتمشى مع خصائص التصور الإسلامي، ولهذا فإنه فهو لا يحفل بمن قال، ولكن الإلئ

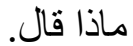
r. إنه لم يحدد للأدب الإسلامي لغة معينة يخصها بذلك، ويحجر على ما سواها من

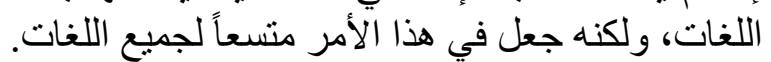

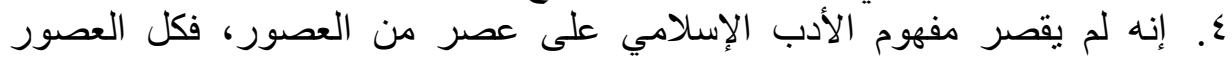
و الأزمنة ـعنده- صالحة لإنتاج الأدب الذبي يلتقي مع تصور الإنسلام للإنسان

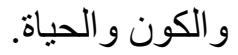

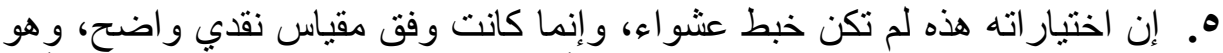
أنه لا يختار من الأعمال إلا ما كان متمشياً مع خصائص التصني التصور الإسلامي كلياً أو

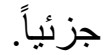
أولاً: دراستئه الفنية والجمالية في القرآن الكريم:

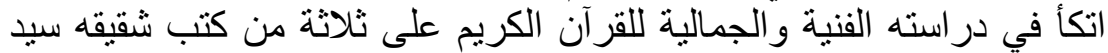

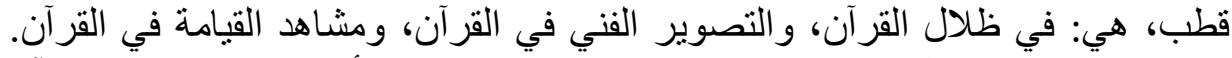

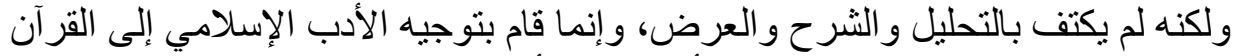

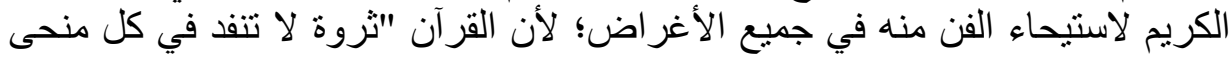

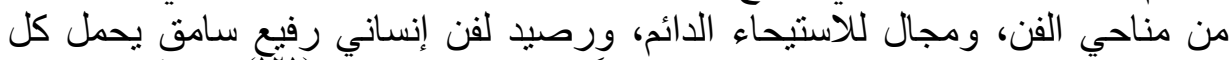

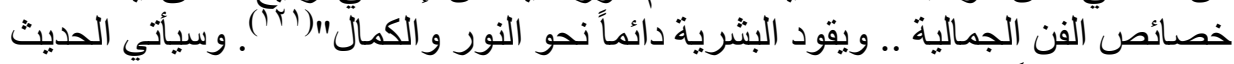
عن ذللك مفصلاً في النقاط الآتية:

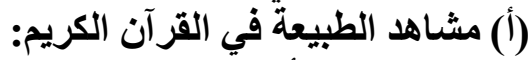

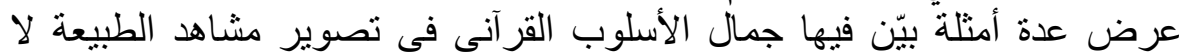

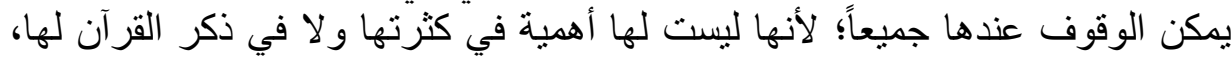

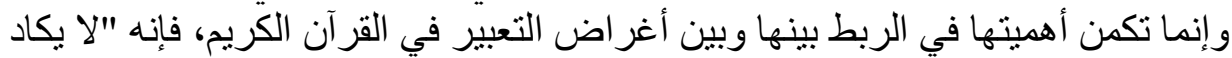


يوجد غرض من أغراض التعبير في القرآن لم تستخدم فيه الطبيعة لإحيائه في النفس

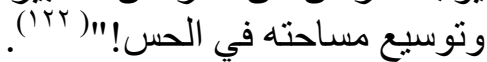

ولهذا فهو يرى أن القرآن يوجه النظر إلى مجالي الطبيعة في أمثلة كثيرة جداً

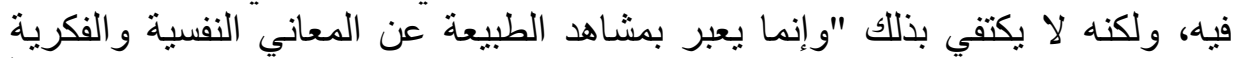

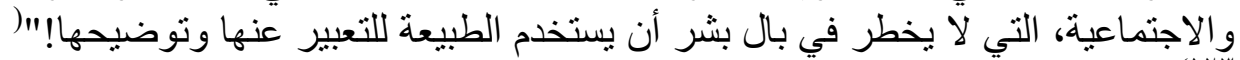

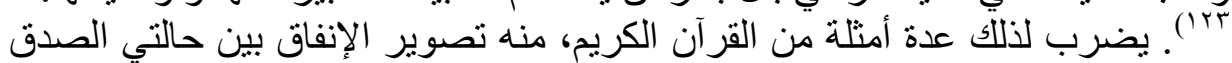

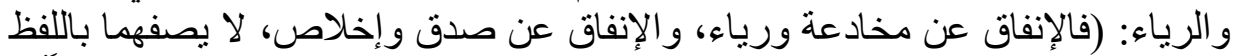

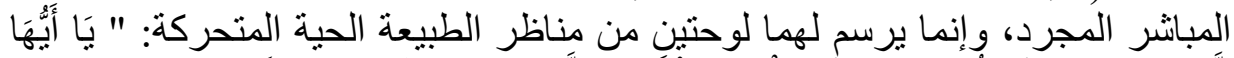

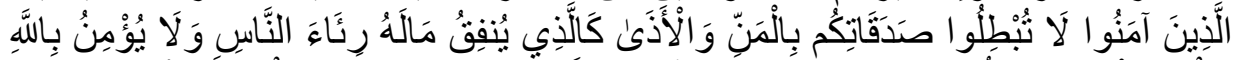

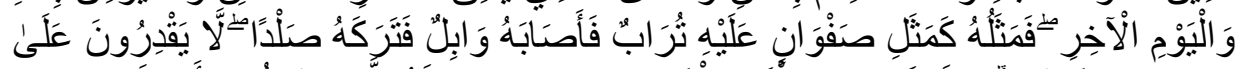

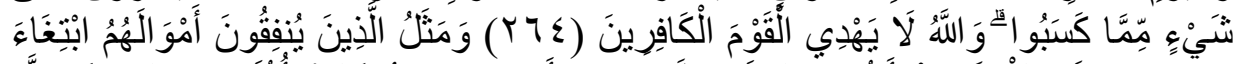

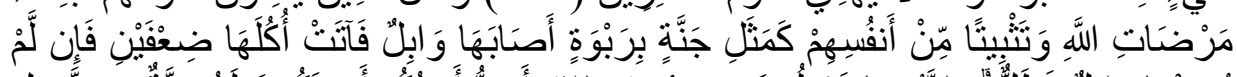

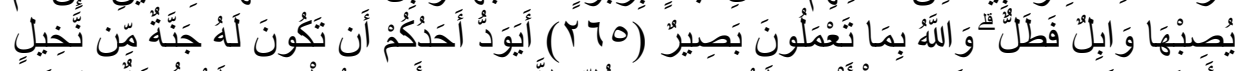

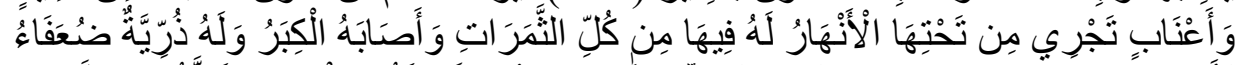

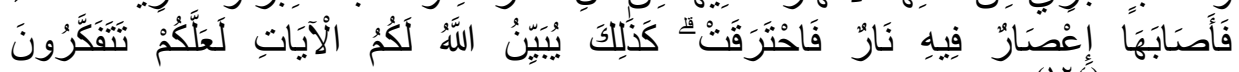

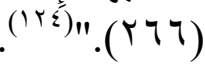
و هو يرى في هذا المشهد أن المعنى المجرد ـالإنفاقـ تحول إلى معنى حي متحرك؛

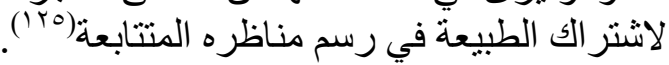

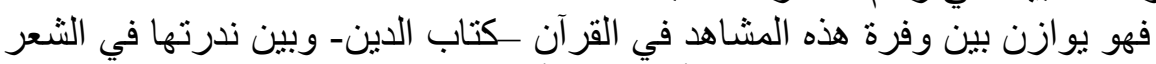

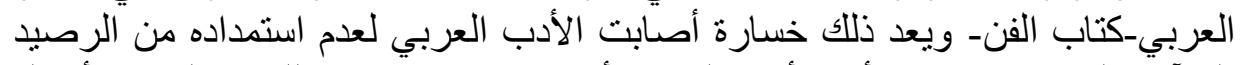

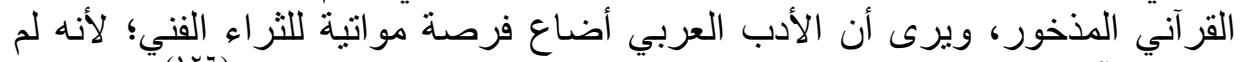

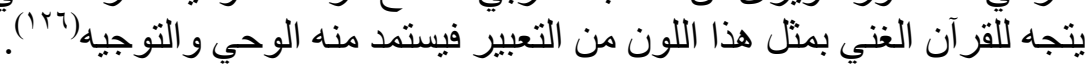

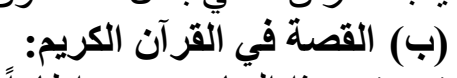

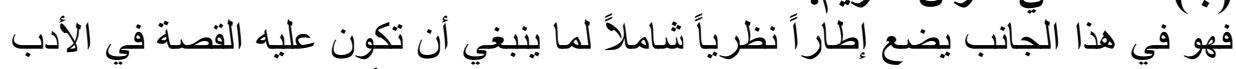

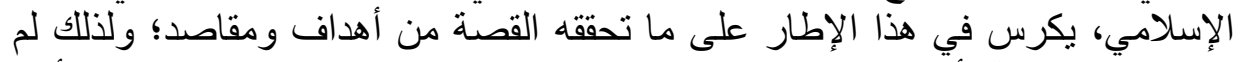

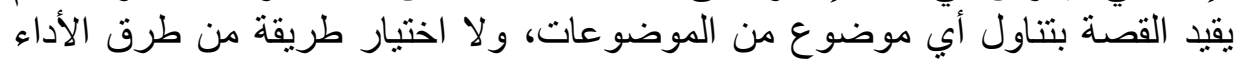

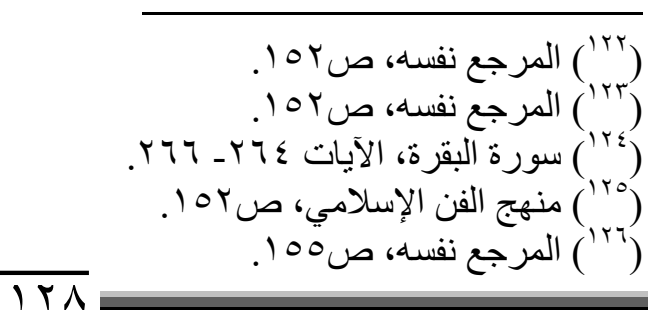


بشرط أن "يستمد تصوره للحياة والأحداث والأشياء من التصور الإسلامي، أو على الإنى

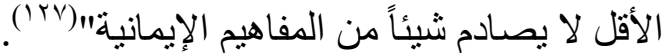

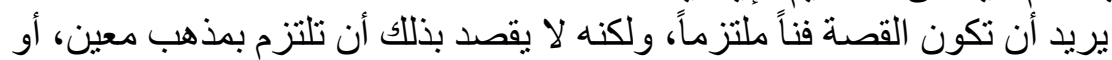

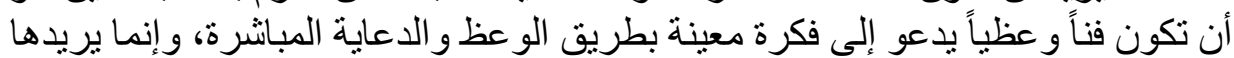

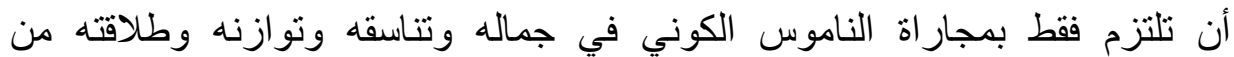

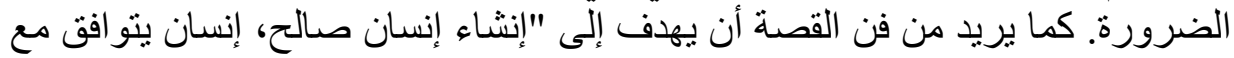

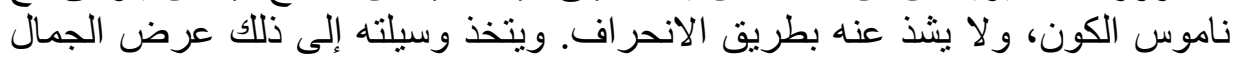

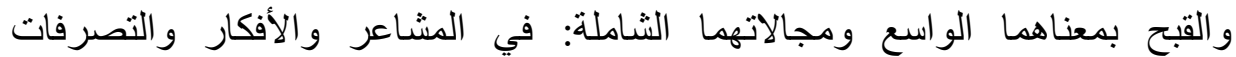

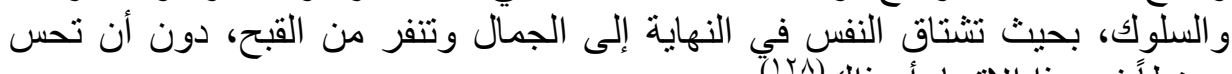

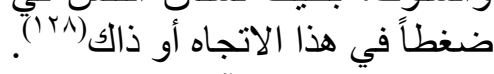

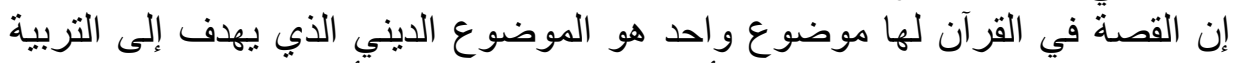

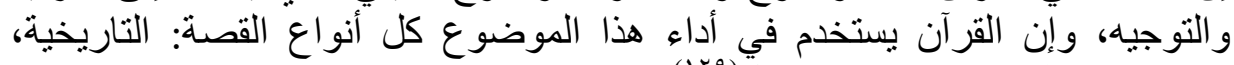

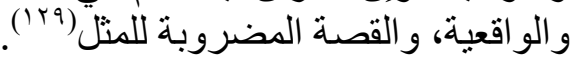
ثم يمضي بعد ذلك إلى إيضاح أبرز السمات أو القوات العد التي ينبغي مر اعاتها في

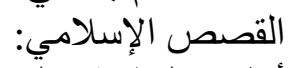

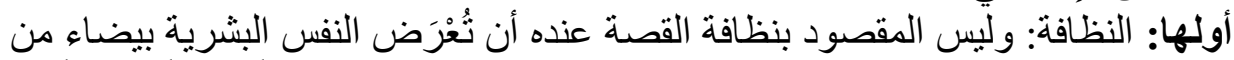

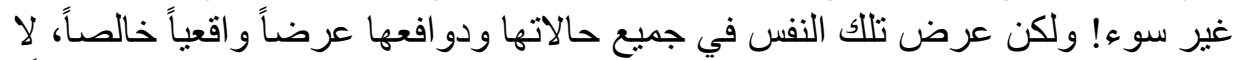

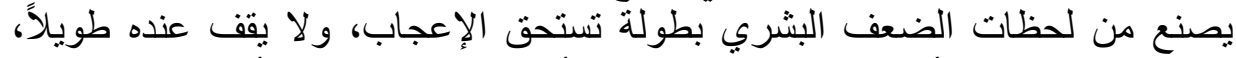

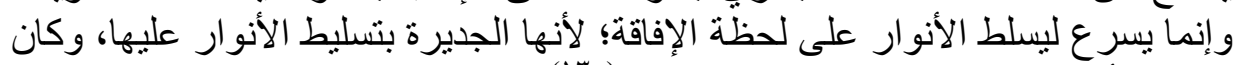

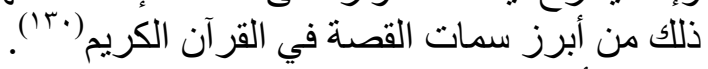

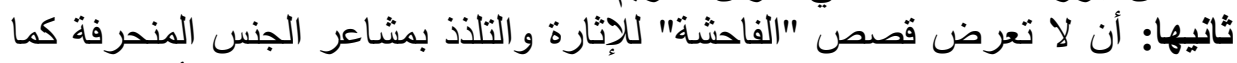

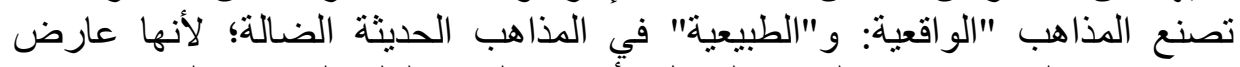

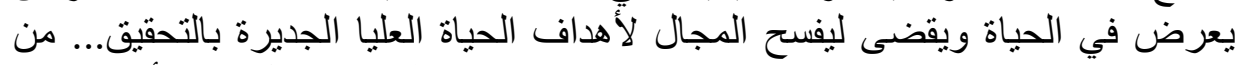

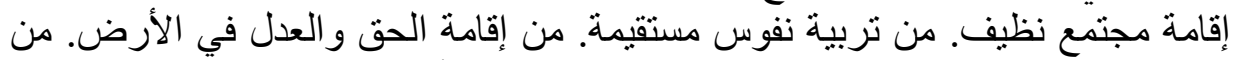

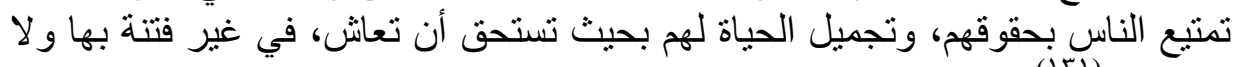

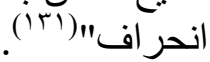




\section{د. حسّان بشير حسّان حامل}

ثم يلخص الخصائص الفنية للقصة في القرآن من كتاب "التصوير الفني في

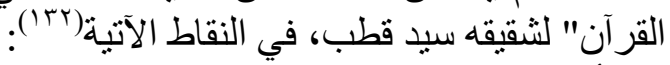

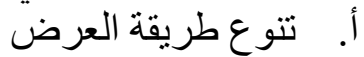
ب. تنوع طريقة المفاجأة ج. ترك فجو فروات بين كل مشهدين أو حلقتين يملؤ ها الخيال. د. د. التصوير ثم يسدد طعنات شداد للأدب العربي، إذ يرى أنه منذ نشأته إلى ما قبيل العصدر

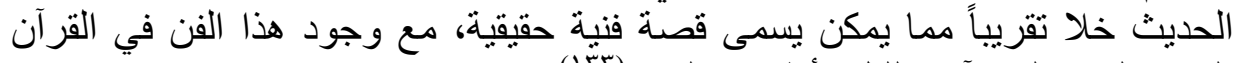

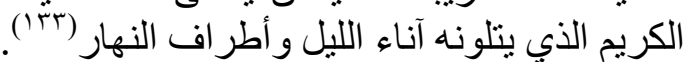

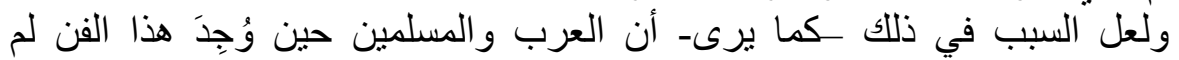

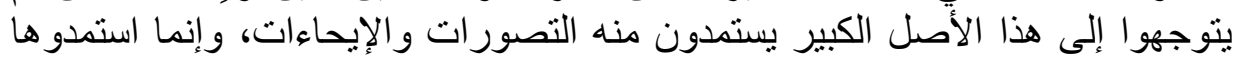

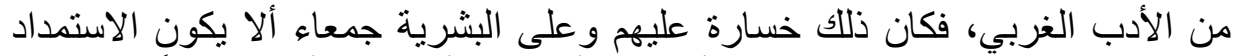

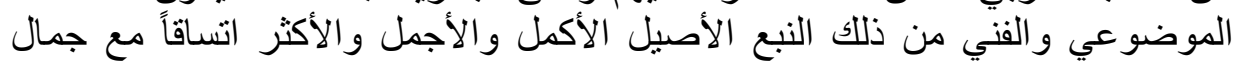

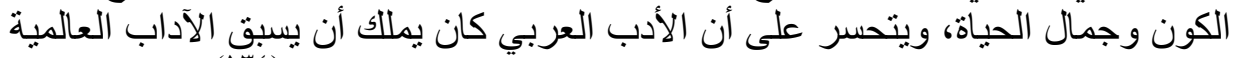

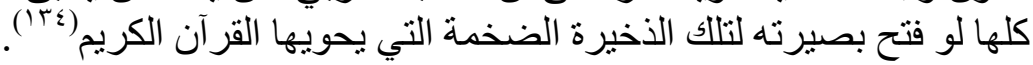

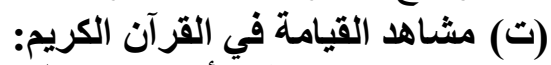

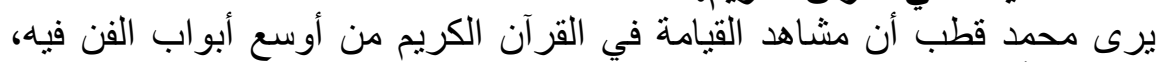

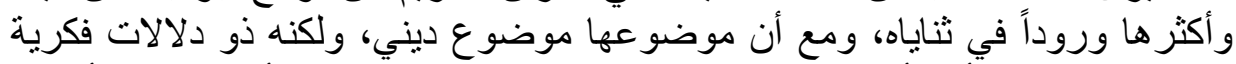

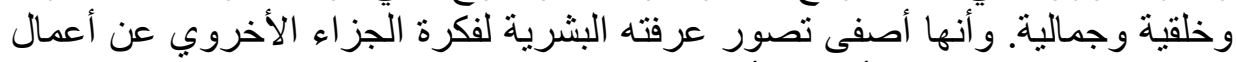

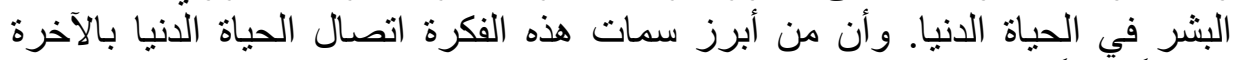

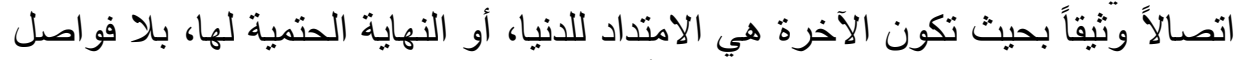

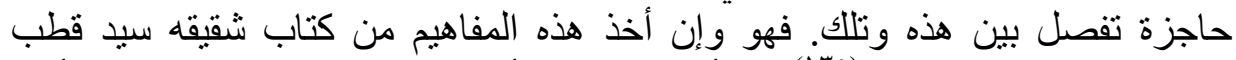

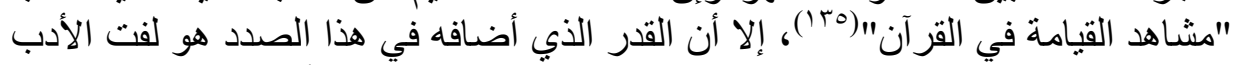

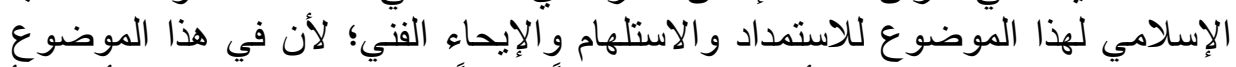

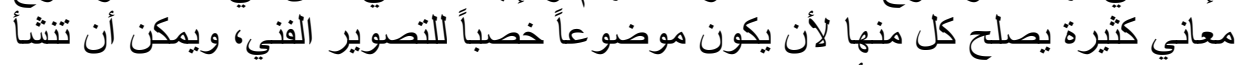

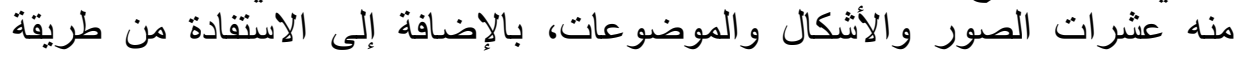

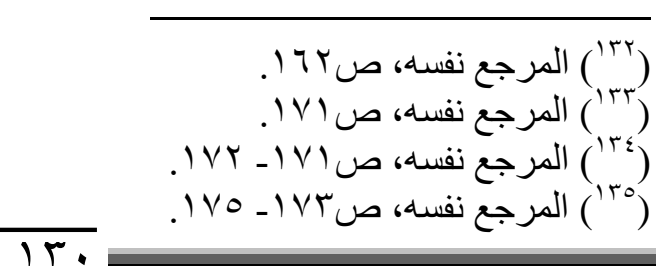


الأعماق القرآني في إحباء هذه المشاهد، وهز النفس بها هزاً عنيفاً ليبلغ التأثر فيها إلى

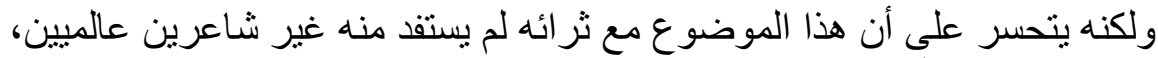

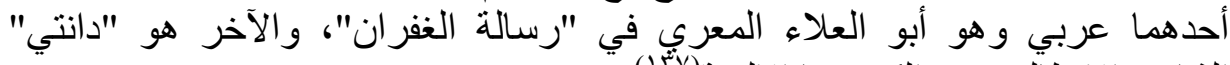

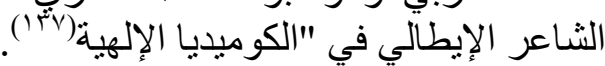

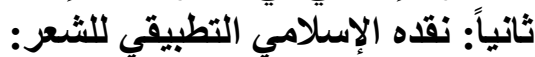
اختار لهذا الجانب من التطبيق و الدر اسة خمسة من الثعر اء كلهم من المسلمين إلا واحداً، وسيأتي الحديث عنهم مفصلاً فيما يأتي:

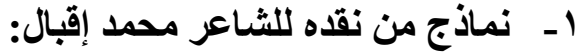

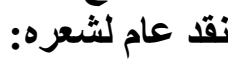

يذهب إلى أن شعر محمد إقبال بنقسم إلى قسمين: القسم الأول وهو الجزء

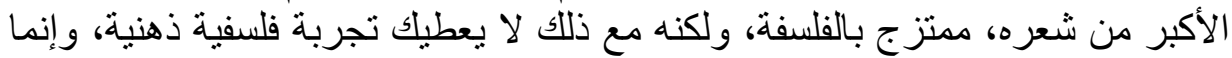

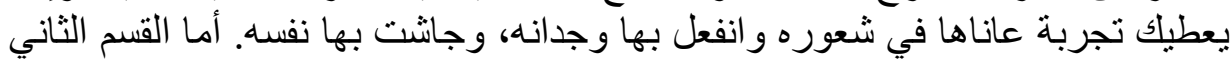

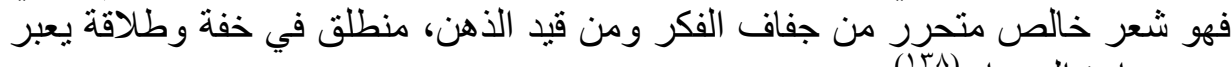

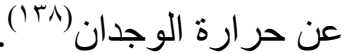

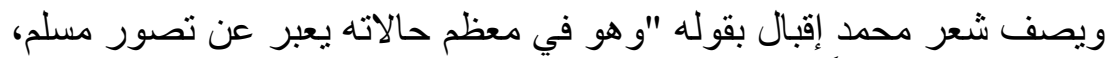

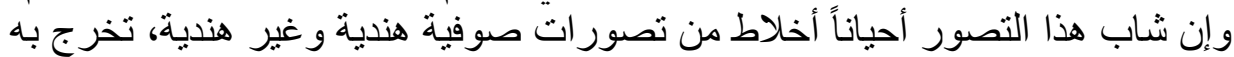

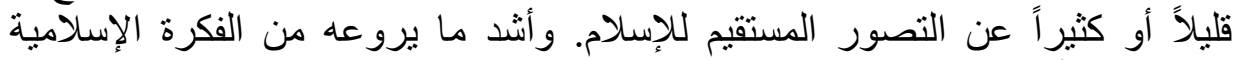

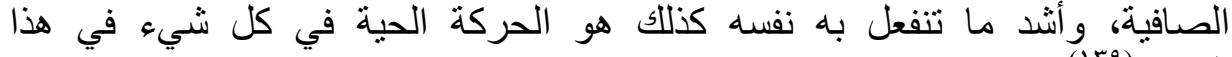

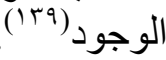

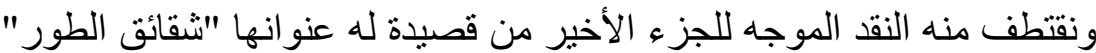

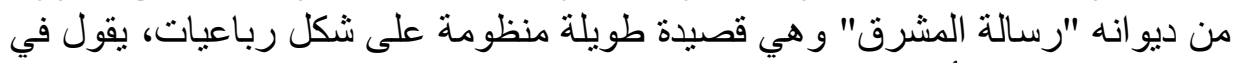

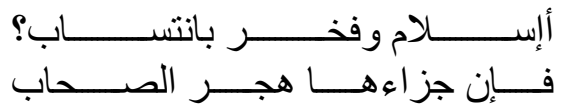

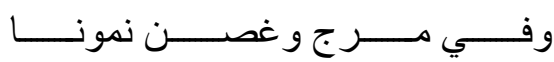

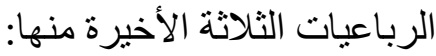

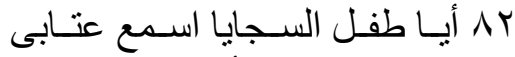

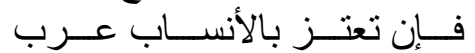

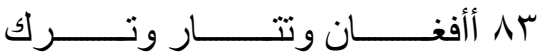




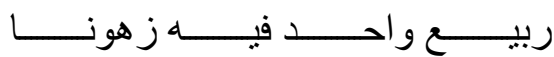

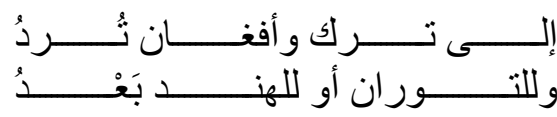

حـــر ام بينتـــــا تفريـــن لــــون

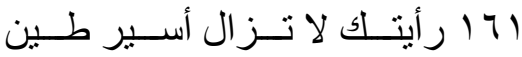

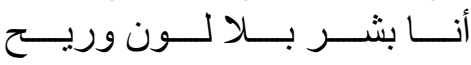

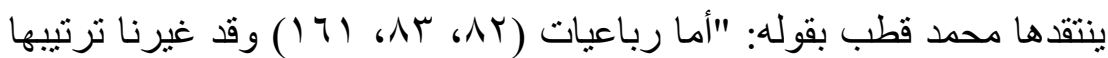

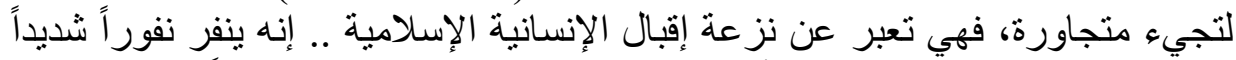

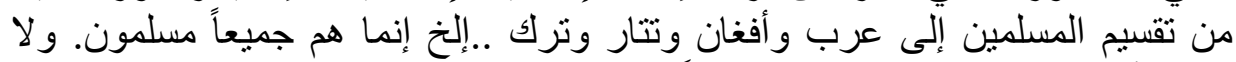

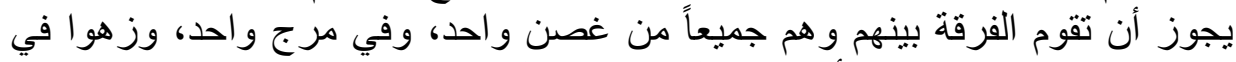

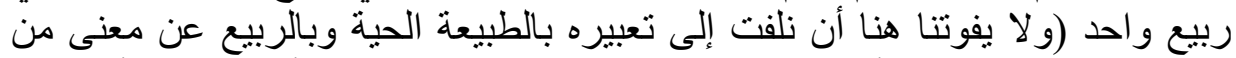

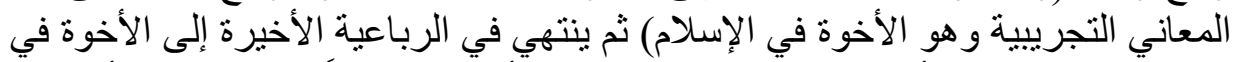

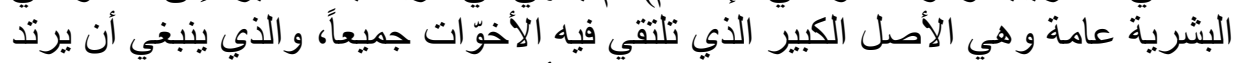

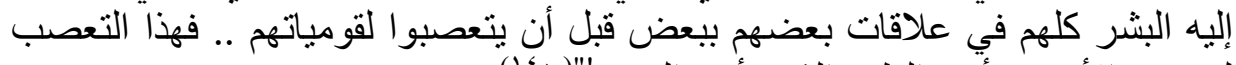

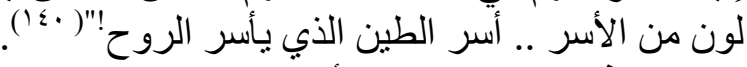

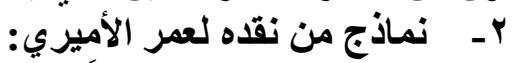

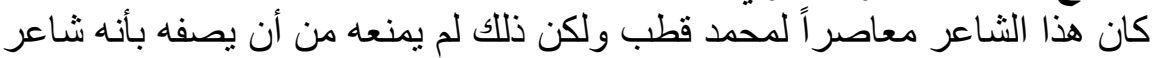

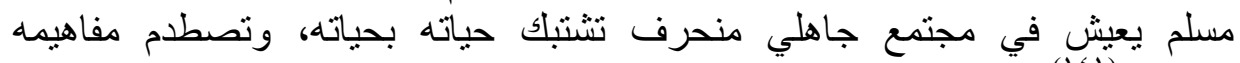
بمفاهيمه(1) وقد اختار له قصيدتين من ديوانه "مع الله" لأنهما تلتقيان مع خصائص التصن التصور

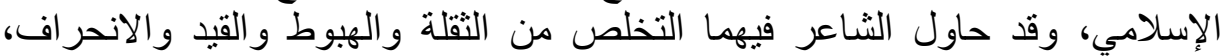

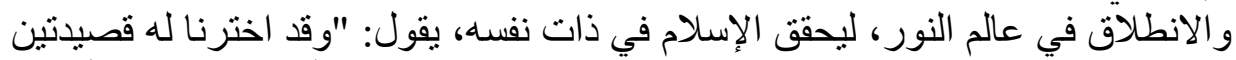

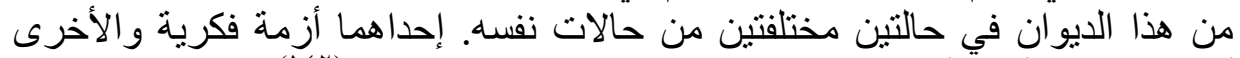

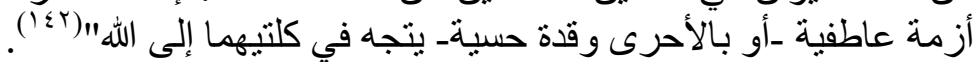

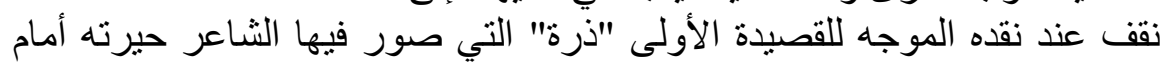

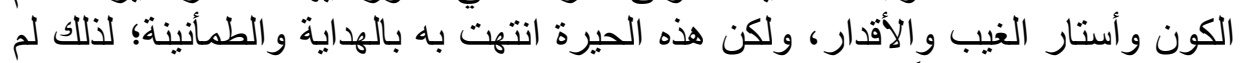

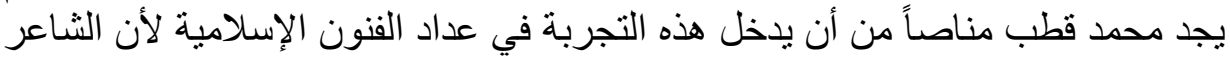

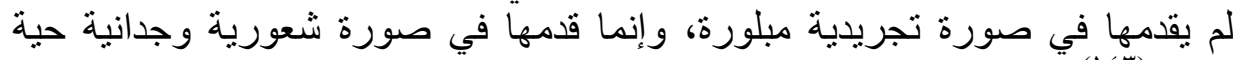
نابضة (1)

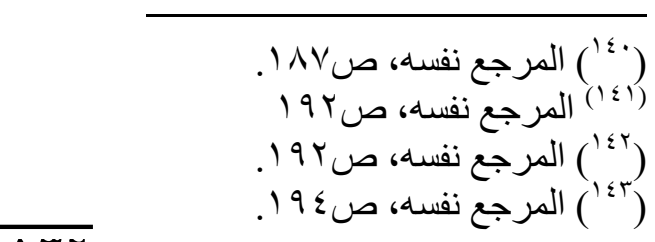




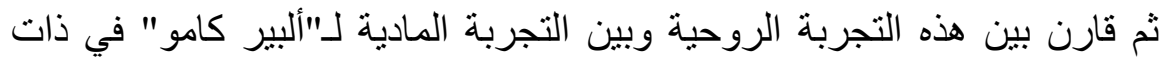

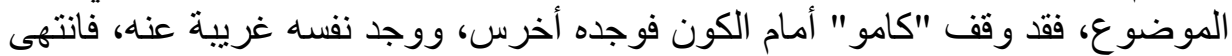

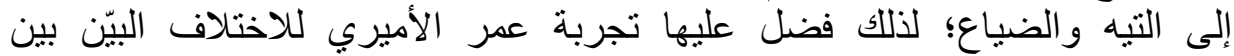

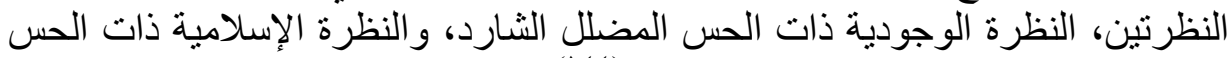

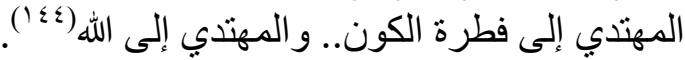
r- - نماذج من نقده لطاغور الكون

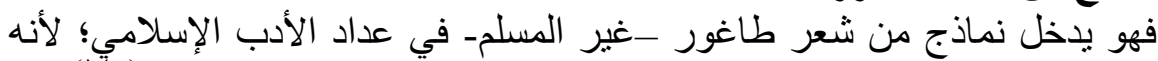

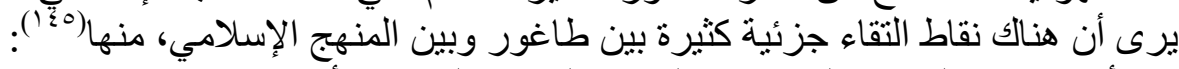

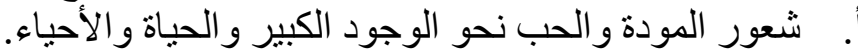

$$
\text { ب. ب. الحب الجميل للإنسانية. }
$$

ج. الدعوة الدائمة للسماحة ولإنسية الخير بين الناس.

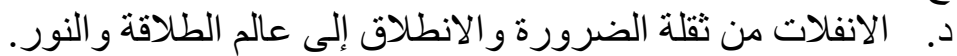

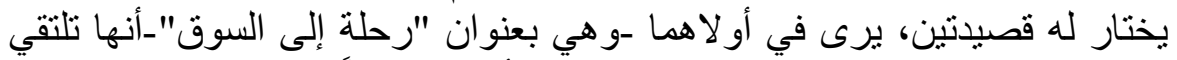

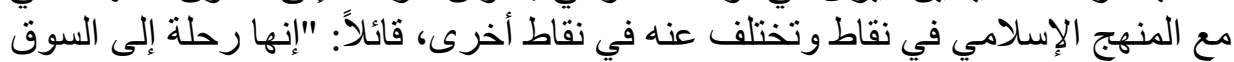

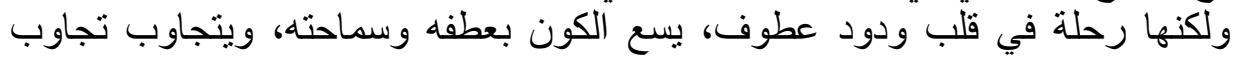

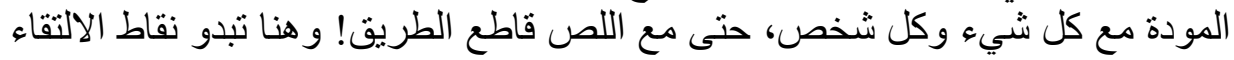

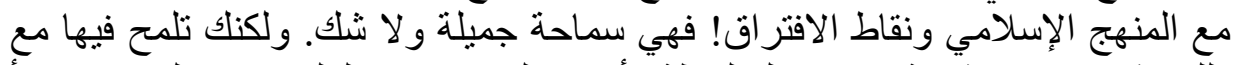

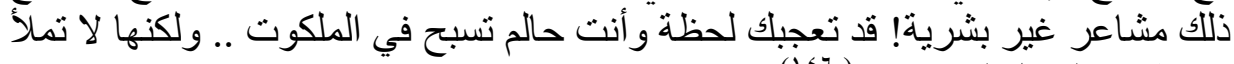

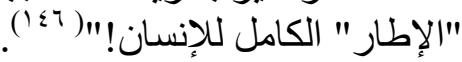

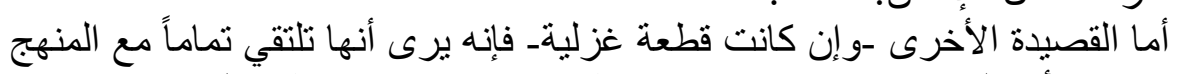

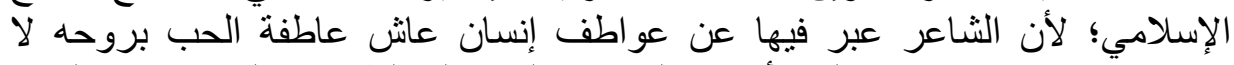

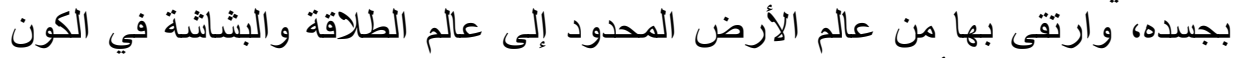

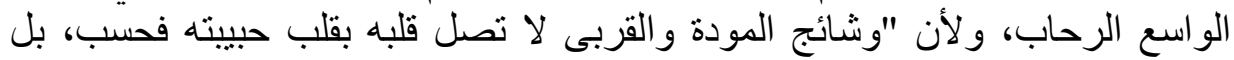

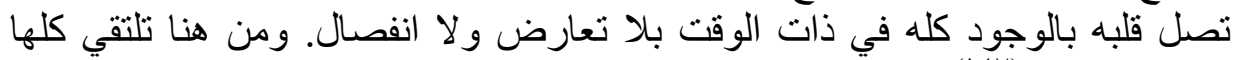

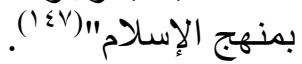

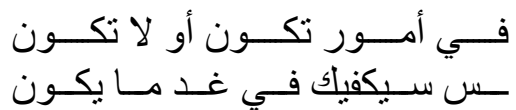
ع - نماذج من نقده لسكينة بنت الإندين:

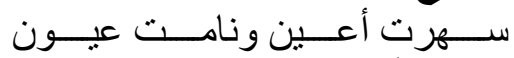

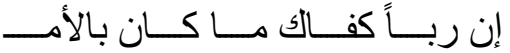

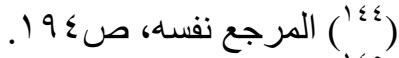

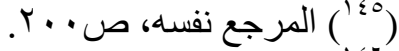

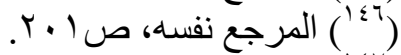


و عن هذين البيتين المنسوبين لها(^؟)، يقول: "هذان بيتان فردان .. لكنهما

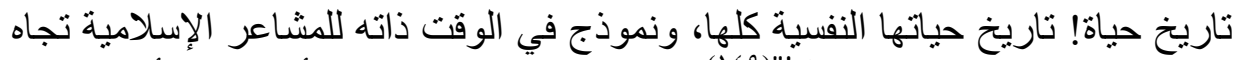

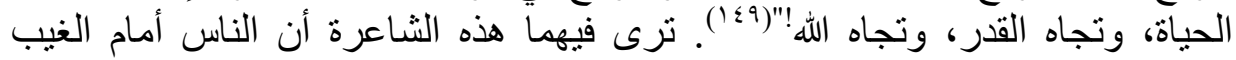

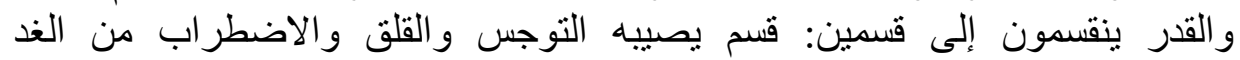

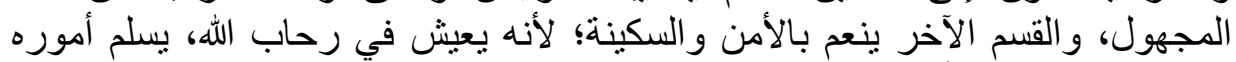

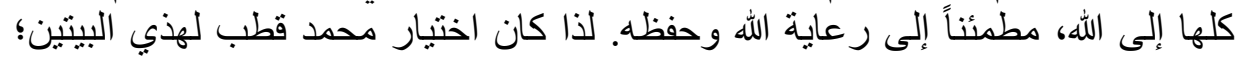

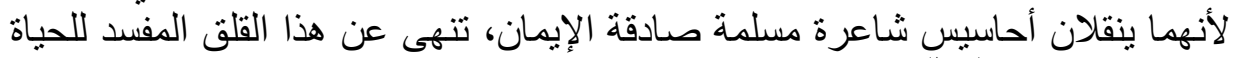
المدمر للأعصاب(10.).

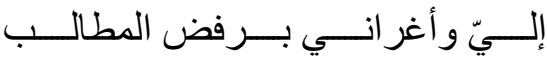

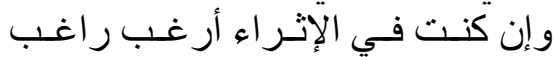

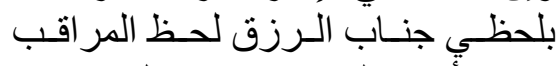

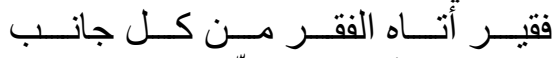

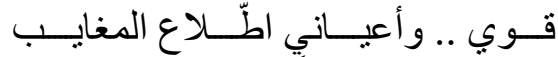

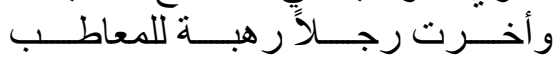

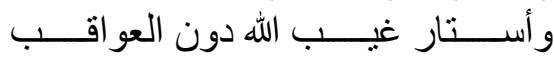
ومسن أيـن و الغايـات بعـد المــذاهب الهب

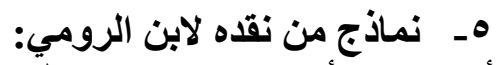

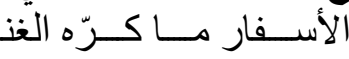
أذاقنت

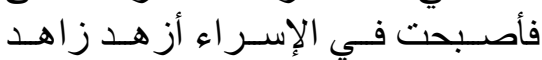

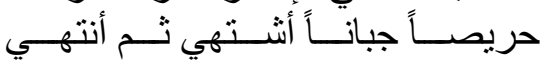

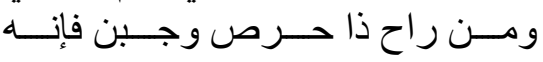

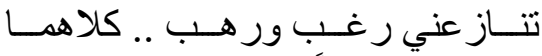

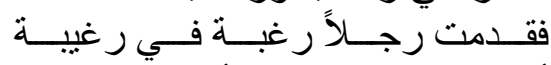

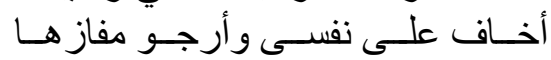

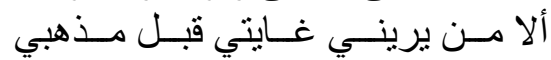

وقد كان سبب اختياره لهذه القطعة لابن الرومي؛ لأن البيتين الأخيرين منها الإنيا

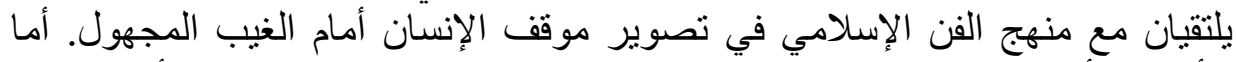

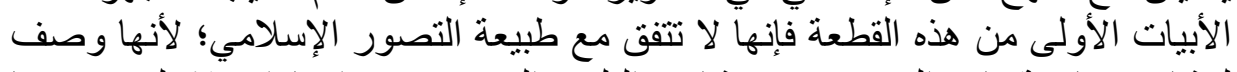

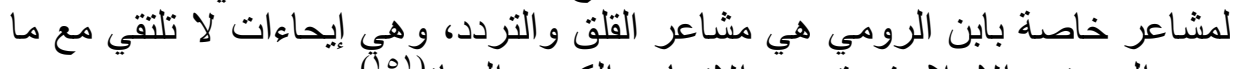

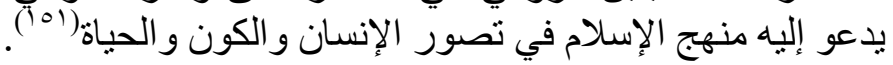
ثالثا: نقده الإسلامي التطبيقي للنثر:

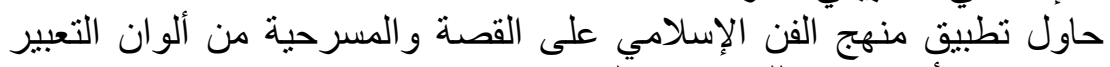
النثرية، وكان موقفه أمام هذين اللونين كما يليّي: 


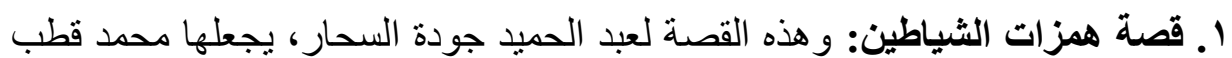

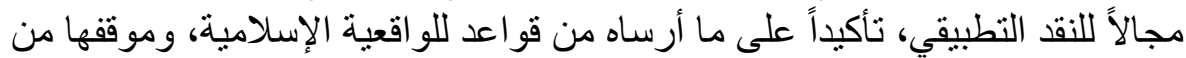

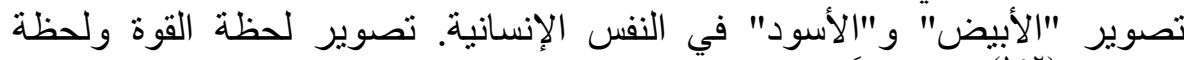

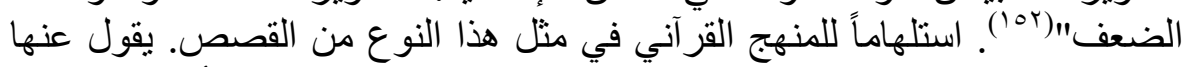

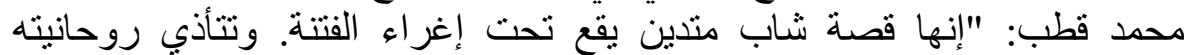

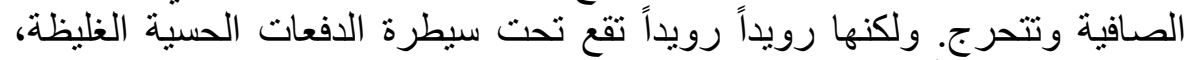

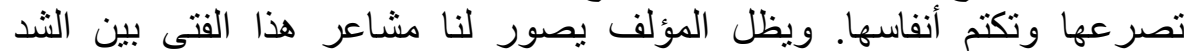

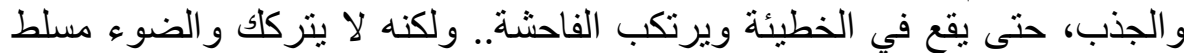

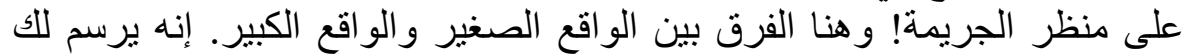

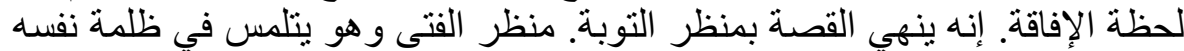

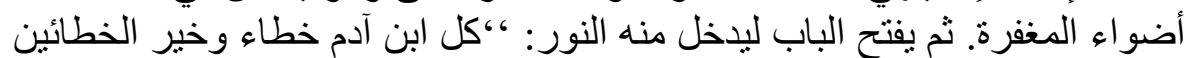

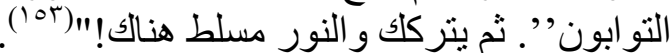

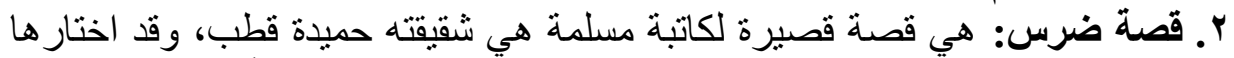

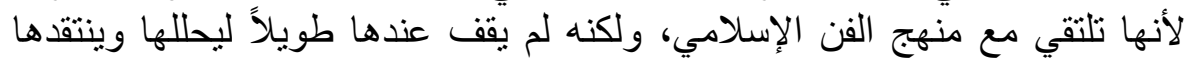

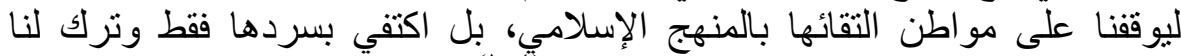

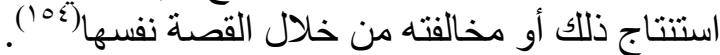

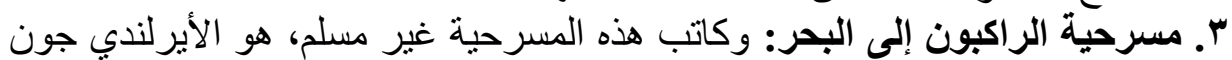

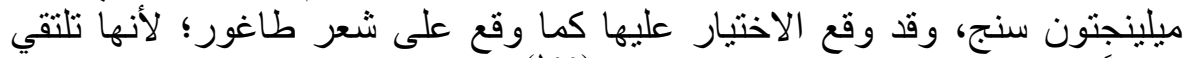
جزئياً مع المنهج الإسلامي في النقاط الآنية النية (100):

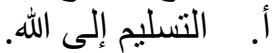

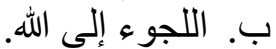
ج. الثعور بالموت على الهُ أنه رد الوديعة إلى الله.

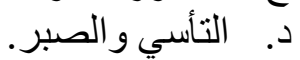
ه. الرضاء بالقدر.

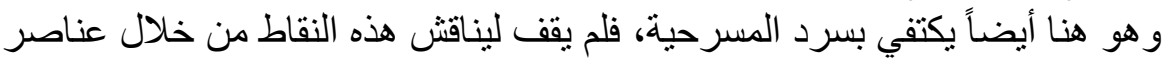

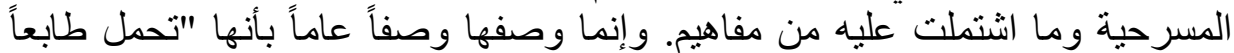




\section{د. حسّان بشَير حسّان حامل}

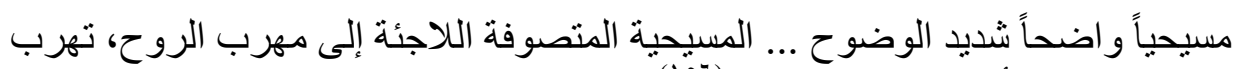

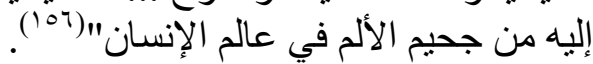

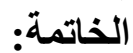

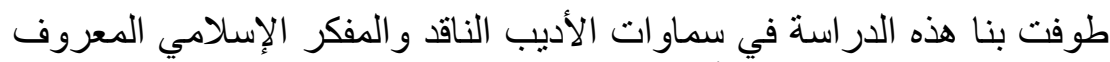

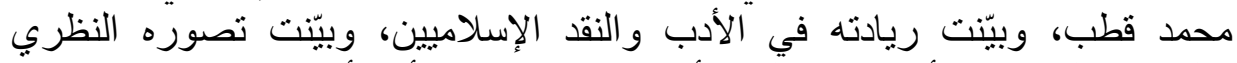

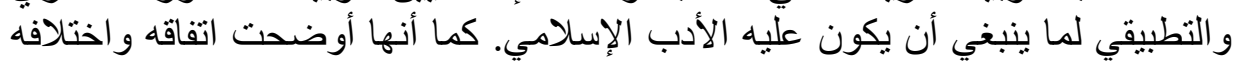

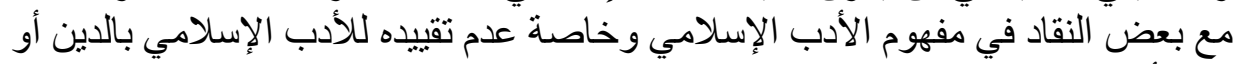

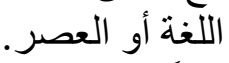

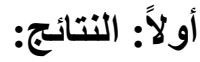

ا أن إن مفهومه للأدب الإسلامي مفهوم واسع جداً؛ لأنه

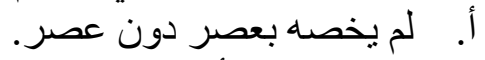

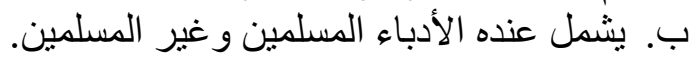

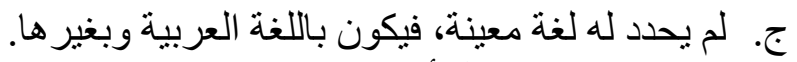

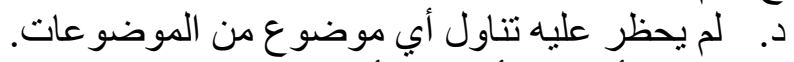

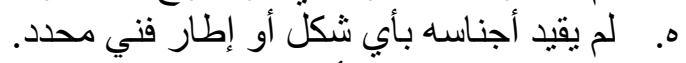

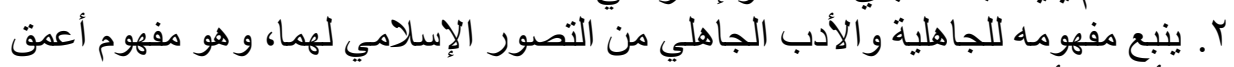

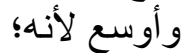

$$
\begin{aligned}
& \text { أ. لـ لم يحصره في فترة زمنية محددة. }
\end{aligned}
$$

ب. لم يقصر معنى الجهل على المهلى المعنى المقابل للعلم، و إنما يحصره في عدم الهداية

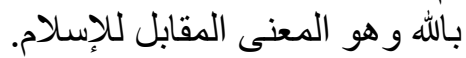

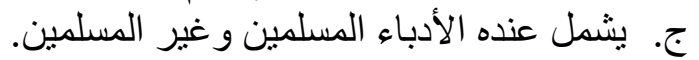

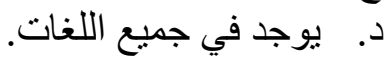

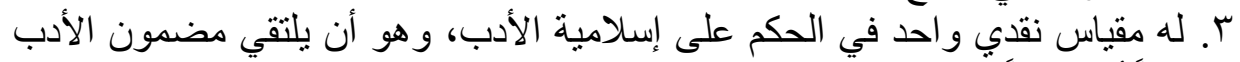

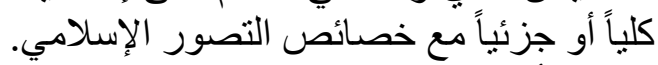

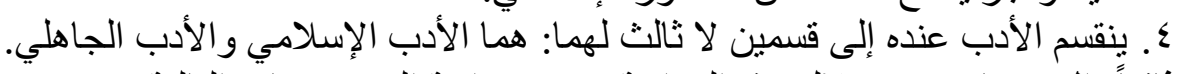

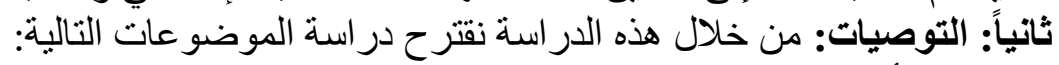

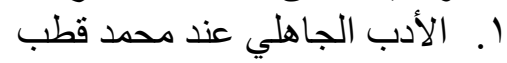

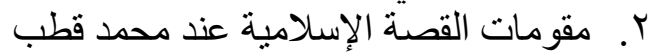

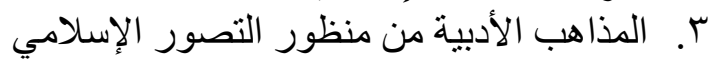


ا. الأدب الإسلامي المفهوم والقضية، د.علي علي صبح وآخرون، دار الجيل،

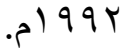

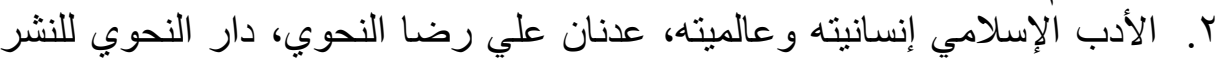

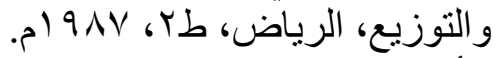

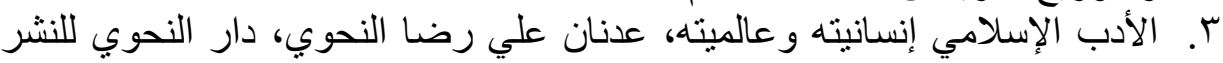

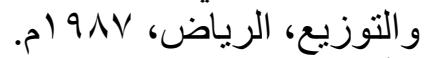
ع. الأدب الإسلامي بين النظرية و التطبيق، صابر عبد الدايم، دار الثروق، القاهرة،

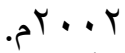
๑. الأدب الإسلامي: مراجعات في النشأة والخصائص، ماجد محمد الماجد، جامعة

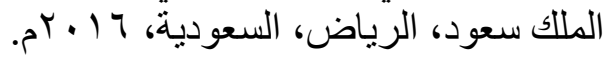

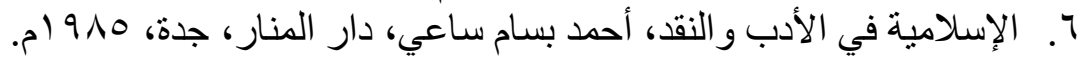

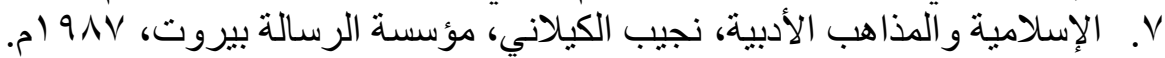

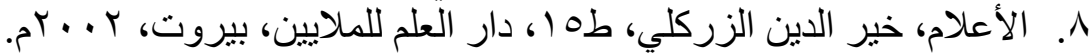

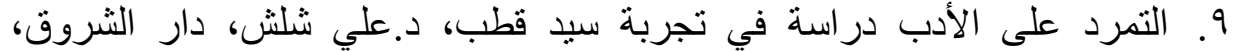
. 199 ـ

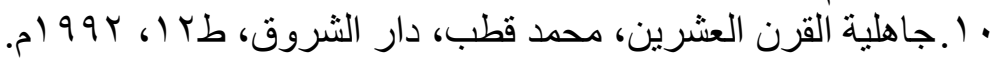

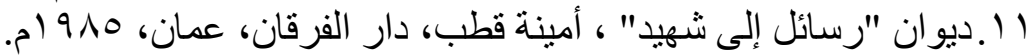

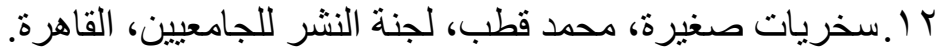

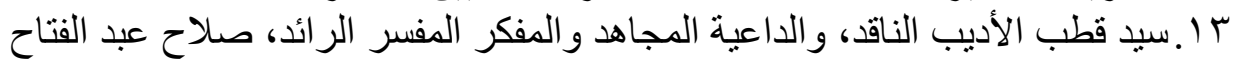

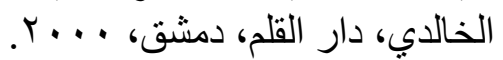

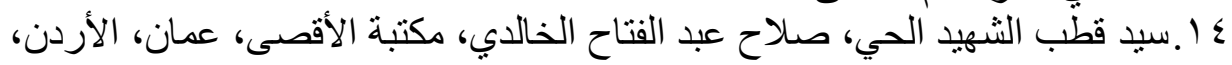
.م) 911 1. سيد قطب ناقداً، أحمد محمد أحمد البدوي، رسالة دكتور اه غير منشورة، جامعة

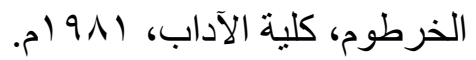

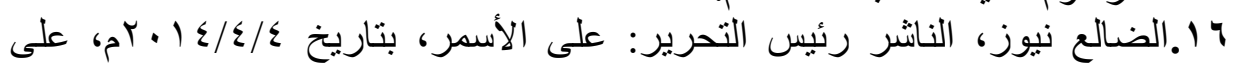
(http://www.addalinews.com/Print/78799) . $1 \mathrm{~V} / \mathrm{M} / \mathrm{rq}$

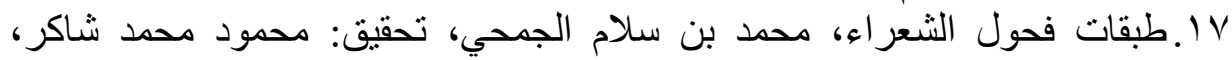

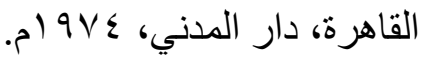

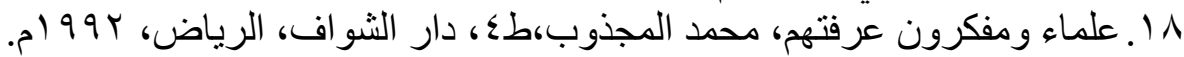




\section{د. حسّان بشير حسّان حامل}

9 1.في الأدب الإسلامي المعاصر، محمد حسن بريغش، مكتبة الحرمين، الرياض، r •r.في الأدب والأدب الإسلامي، محمد الحسناوي، المكتب الإسلامي بيروت، ودار

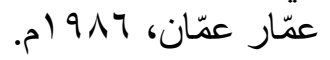
اب.في النقد الإسلامي المعاصر، إندان، عماد الدين خليل، مؤسسة الرسالة، بيروت، دون تاريخ. r r. الكامل في اللغة والأدب، لأبي عباس المبرد، تحقيق: محمد أبو الفضل إبراهيم، دار

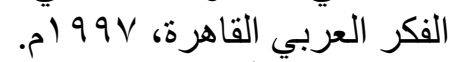

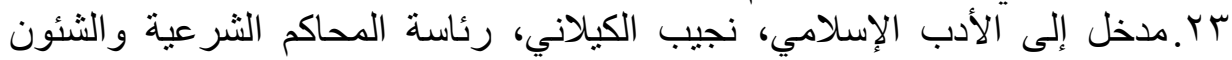

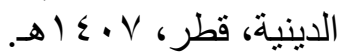
ع ז.مذكرات سائح في الثرق الهُ الأوسط، أبو الحسن الندوي، طب، مؤسسة الرسالة، م 971

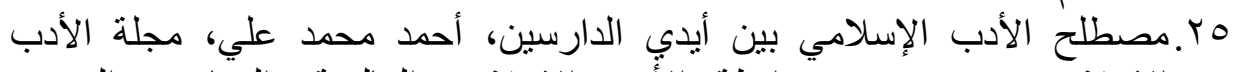
الإسلامي، تصدر عن رابطة الأدب الإسبامي الإسب، العالمية، الرياض، العدده،

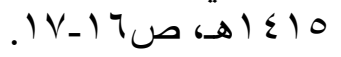

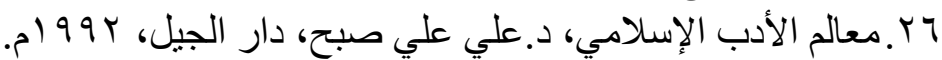

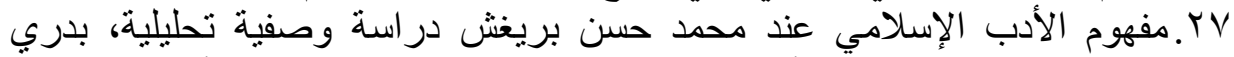

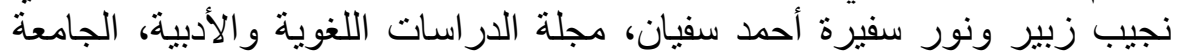

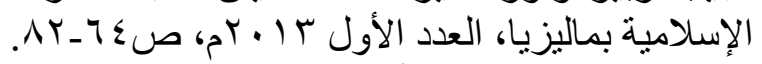

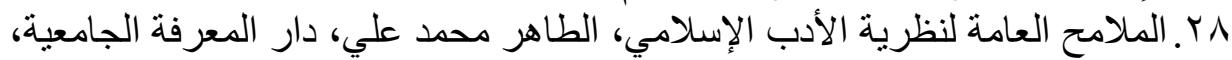

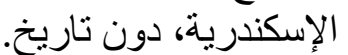
9. الملامح العامة لنظرية الأدب الإسلامي، شلتاغ عبود، دار المعرفة، دمشق، . 994 ••ّ.من قضايا الأدب الإسلامي، صالح آدم بيلو، دار المنارة للنشر، السعودية، جدة، ه 910

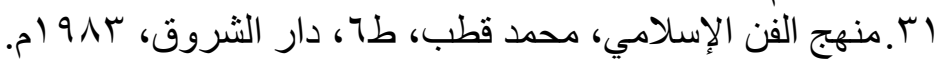

